\title{
Mineralogical Features of Ore Diagenites in the Urals Massive Sulfide Deposits, Russia
}

\author{
Valeriy V. Maslennikov ${ }^{1,2, *}$, Nuriya R. Ayupova ${ }^{1,2}$, Nataliya P. Safina ${ }^{1,2}$, Aleksandr S. Tseluyko ${ }^{1,2}$, \\ Irina Yu. Melekestseva ${ }^{1}$, Ross R. Large ${ }^{3}$, Richard J. Herrington ${ }^{4}{ }^{\mathbb{D}}$, Vasiliy A. Kotlyarov ${ }^{1}$, \\ Ivan A. Blinov $\left.{ }^{1}{ }^{(}\right)$, Svetlana P. Maslennikova ${ }^{1}$ and Svetlana G. Tessalina ${ }^{5}$ \\ 1 Institute of Mineralogy of Uralian Branch, Russian Academy of Science, 456317 Miass, Russia; \\ aupova@mineralogy.ru (N.R.A.); natali.safina2015@yandex.ru (N.P.S.); celyukoa@rambler.ru (A.S.T.); \\ melekestseva-irina@yandex.ru (I.Y.M.); kotlyarov@mineralogy.ru (V.A.K.); ivan_a_blinov@mail.ru (I.A.B.); \\ svmas@mineralogy.ru (S.P.M.) \\ 2 National Research South Urals State University, Octyabrya Str. 16, 456301 Chelyabinsk, Russia \\ 3 CODES Centre for Ore Deposits and Earth Sciences, Private Bag 79, University of Tasmania, \\ Tasmania 7001, Australia; ross.large@utas.edu.au \\ 4 LODE London centre for Ore Deposits, Department of Earth Sciences, Natural History Museum, \\ Cromwell Road, London SW7 5BD, UK; r.herrington@nhm.ac.uk \\ 5 John de Laeter Centre for Isotope Research, Curtin University, Kent St., Bentley 6102, WA, Australia; \\ svetlana.tessalina@curtin.edu.au \\ * Correspondence: mas@mineralogy.ru
}

Received: 29 December 2018; Accepted: 28 February 2019; Published: 28 February 2019

\begin{abstract}
In weakly metamorphosed massive sulfide deposits of the Urals (Dergamysh, Yubileynoe, Yaman-Kasy, Molodezhnoe, Valentorskoe, Aleksandrinskoe, Saf'yanovskoe), banded sulfides (ore diagenites) are recognized as the products of seafloor supergene alteration (halmyrolysis) of fine-clastic sulfide sediments and further diagenesis leading to the formation of authigenic mineralization. The ore diagenites are subdivided into pyrrhotite-, chalcopyrite-, bornite-, sphalerite-, barite- and hematite-rich types. The relative contents of sphalerite-, bornite- and barite-rich facies increases in the progression from ultramafic (=Atlantic) to bimodal mafic (=Uralian) and bimodal felsic (=Baymak and Rudny Altay) types of massive sulfide deposits. The ore diagenites have lost primary features within the ore clasts and dominantly exhibit replacement and neo-formed nodular microtextures. The evolution of the mineralogy is dependent on the original primary composition, sizes and proportions of the hydrothermal ore clasts mixed with lithic serpentinite and hyaloclastic volcanic fragments together with carbonaceous and calcareous fragments. Each type of ore diagenite is characterized by specific rare mineral assemblages: $\mathrm{Cu}-\mathrm{Co}-\mathrm{Ni}$ sulfides are common in pyrrhotite-rich diagenites; tellurides and selenides in chalcopyrite-rich diagenites; minerals of the germanite group and $\mathrm{Cu}-\mathrm{Ag}$ and $\mathrm{Cu}-\mathrm{Sn}$ sulfides in bornite-rich diagenites; abundant galena and sulfosalts in bariteand sphalerite-rich diagenites and diverse tellurides characterize hematite-rich diagenites. Native gold in variable amounts is typical of all types of diagenites.
\end{abstract}

Keywords: halmyrolysis; ore diagenite; enrichment; leaching; seafloor alteration and oxidation; rare mineral assemblages; massive sulfide deposits; the Urals

\section{Introduction}

The origin of banded sulfides in ancient massive sulfide deposits is a key point of discussion between authors favoring "hydrothermal replacement" or brine-pool hydrothermal-sedimentary models versus those preferring a "reworked black smoker" model for the formation of volcanic-hosted massive sulfide (VHMS) deposits [1-3]. The fine-grained laminated structure of alternating 
monomineral layers of pyrite, pyrrhotite, carbonate, quartz, chlorite, magnetite, framboidal and colloform pyrite is consistent with their hydrothermal sedimentary origin. Primary textures are better preserved in some deposits than in others due to their lower degree of deformation [1]. Numerous publications support a hydrothermal-sedimentary model but only a few discuss the possible influence of diagenesis on the textural and mineral evolution of chemically precipitated hydrothermal sulfide sediments [4-8]. In the Urals, Yarosh (1973) first recognized the differences between diagenetic and metamorphic alteration of massive sulfide deposits [9].

Seafloor weathering (halmyrolysis s.s.) and the related dissolution, breakdown and reworking of consolidated ores of ancient sulfide mounds have been suggested for the origin of sulfide breccias and fine-grained sulfide sandstones leading through to full oxidation, leaching and development of enrichment zones [10-12]. This model has been confirmed as a viable mechanism through the detailed study of eroded modern smoker mounds, in which supergene enrichment results in complete or partial replacement of primary sulfides by secondary sulfides and the formation of gossans [13-15].

Other publications propose the concept of recurrent halmyrolysis in addition to simple diagenesis of layered clastic sulfide sediments of the Urals VHMS deposits [16-23]. Recently, recurrent seafloor alteration of clastic sulfide sediments, leading to formation of authigenic minerals in sulfide breccias and sulfide sandstones was reported for the Menez Gwen and Semenov-3 hydrothermal fields, Mid-Atlantic Ridge [24,25]. This work contributes to the emerging theory of halmyrolysis and diagenesis of sulfide sediments [17-19,26]. In this paper, we define the terms "halmyrolysis", "diagenesis" and "ore diagenites" to clear up inconsistencies in definitions published in diverse publications [18,19,27-29].

The term "halmyrolysis" was suggested by K. Hümmel for seafloor weathering of sediments in basins with low sedimentation rates or in submarine volcanic areas [30]. The Dictionary of Earth Sciences describes halmyrolysis as 'Early diagenesis, modification or decomposition of sediments on the seafloor'. Submarine hydrothermal fields with reactive sulfide sediments are additional environments favorable for halmyrolysis which should include all chemical, biochemical and physicochemical processes of seafloor decay (disintegration, decomposition) of sediments (including clastic sulfides) and/or rocks (including consolidated sulfide ores) due to active interaction with oxygenated seawater during preburial and later stages of diagenesis. Halmyrolysis includes oxidation, dissolution, hydration, ion exchange and other processes of disintegration.

Halmyrolysis, in a similar fashion to continental weathering, includes the decomposition of minerals with the loss of elements, compensated by the gain of seawater and oxygen, but contrasts with the removal of seawater and oxygen from minerals during the process of sediment diagenesis. Halmyrolysis can also continue after diagenesis of sulfide sediments inside the consolidated ores if they are still exposed on the seafloor after primary lithification. Halmyrolysis of sulfide deposits can trigger supergene processes of full oxidation of $\mathrm{Fe}^{2+}$ accompanied by both the leaching of metals and their enrichment in clastic sulfide sediments $[12,17,18,31,32]$. The complete seafloor weathering of sediments and rock/ores leads to the formation of silica-rich or ferruginous "halmyrolytes", which have almost completely lost their primary sedimentary features [20].

In this paper, we use the term "diagenesis" to include all types of alteration occurring in sediments prior to their lithification and metamorphism. Diagenesis is a process of compaction, cementation, replacement, crystallization, hydration, dewatering, bacterial activity, and formation of nodules and other forms of authigenic minerals. From the physicochemical viewpoint, diagenesis is an equilibration of minerals with both each other and aquatic environments under conditions of increasing temperature and pressure. Halmyrolysis can be part of the diagenetic process since diagenetic alterations are mostly constructive rather than destructive, occurring largely at the burial stage of lithification. Halmyrolysis can be a recurrent process acting on lithified sulfide mounds and soft sulfide turbidites 
also. The products of halmyrolytic breakdown can thus be redeposited, whereas diagenesis leads to the formation of lithified rocks/ores.

Diagenesis is subdivided into two main stages: early and late. Early diagenesis is the alteration of sediments whilst oxygen is still present in the pore spaces during the preburial stage. In reactive sulfide sediments, the initial process of early diagenesis could be considered a recurrent scenario of halmyrolysis with the dissolution of small ore fragments occurring with the trapped oxygen. Local consumption of oxygen and supersaturation in metals would then be favorable for the crystallization of authigenic sulfides. The replacement of sulfides by new sulfides and iron hydroxides or barite typically occurs during early diagenesis due to the different electrochemical potential of minerals in the presence of an electrolyte like seawater [18]. Late diagenesis is the process of the shallow burial transformation of sediments to lithified sedimentary rocks which would include the formation of pyrite nodules and euhedral pyrite and crystallization, cementation and consolidation of sediment under reducing conditions. After the lithification of sediments, late diagenesis evolves to "catagenesis" [33] or "anadiagenesis" [27], which is a long process of deep-burial epigenetic alteration of rocks/ores prior to metamorphism.

The term diagenite refers to a rock formed by diagenesis. In this paper, the term "ore diagenite" is a product of the diagenetic transformation of sulfide- or barite-rich sediments which have almost completely lost their primary clastic microtextural and mineralogical features by processes including halmyrolysis [19]. In diagenites, "authigenic" minerals are of diagenetic origin, formed in situ.

In weakly metamorphosed massive sulfide deposits of the Urals, the banded sulfides are recognized as seafloor altered clastic sulfide layers intercalated with pyrite cherts, chlorite shales and ferruginous halmyrolites, which are the products of halmyrolysis of lithic sedimentary fragments mixed with sulfides and barite [12,17-20,34]. The clastic sulfides range from breccias to turbidites accompanied by an increasing degree of seafloor alteration to the finer, upper part of the layers [22]. The aim of this paper is to highlight the microtextural and mineralogical diversity of ore diagenites formed after sulfide and barite turbidites. Based on these observations, the importance of halmyrolysis and diagenesis in the evolution of clastic sulfides is considered in the range of primary VHMS deposit types.

\section{Geological Setting and Types of the Deposits Studied}

Several reviews describe the geological setting of the Urals VHMS deposits (hereafter, deposits) [17,19,32,35-45]. The deposits studied were formed in a range of tectonic settings, including marginal sea (Yaman-Kasy), fore-arc basin (Dergamysh), bimodal mafic (Yubileynoe, Molodezhnoe), and felsic (Saf'yanovskoe deposit) intra-arc basin settings, see Figure 1. 


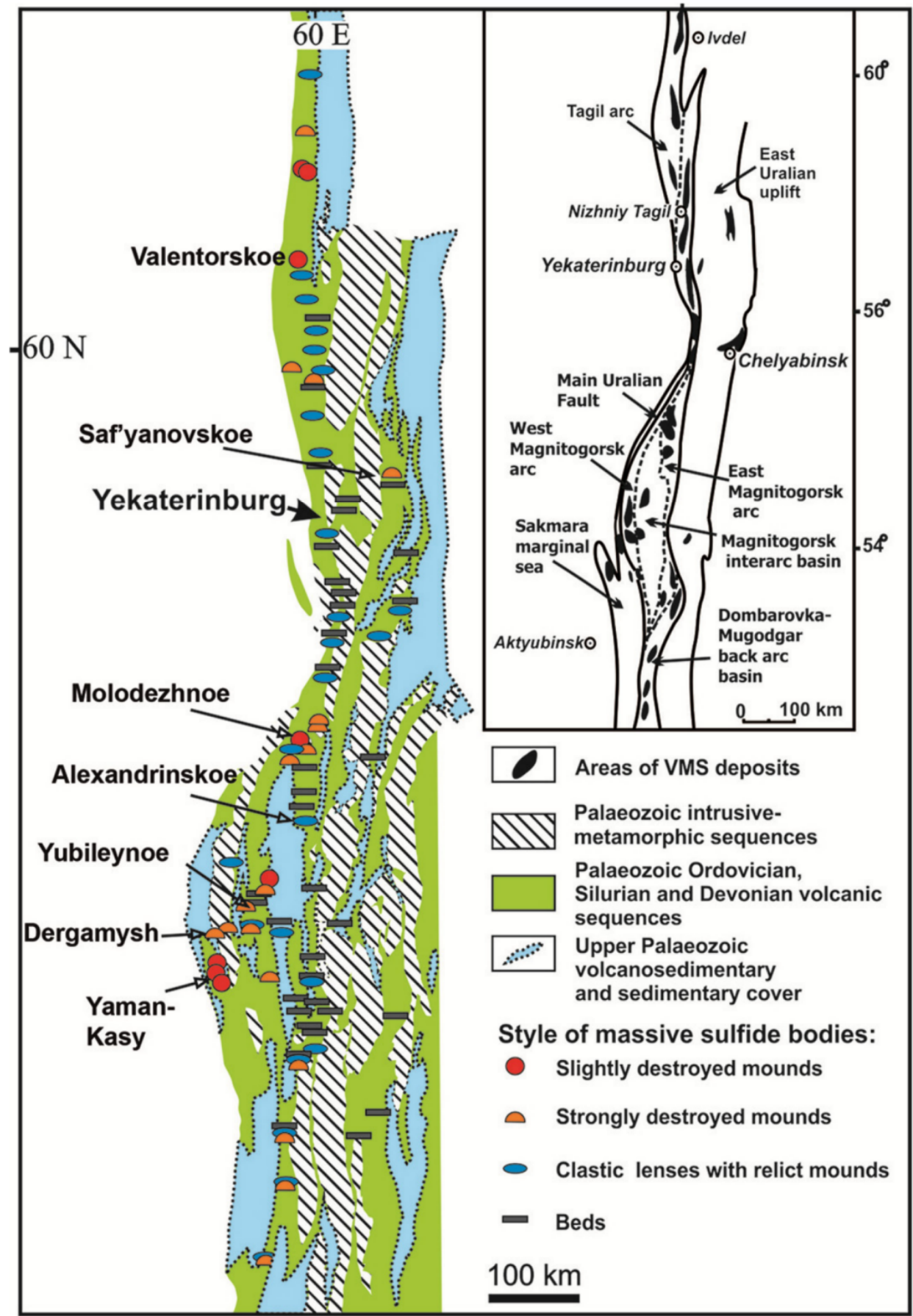

Figure 1. Geological position of the Urals volcanic-hosted massive sulfide (VHMS) deposits (modified after [19,45,46]).

In the Urals, the deposits are subdivided into five types: Atlantic, Cyprus, Uralian, Baymak, and Rudny Altay, see Figure $2[35,36,39,41,42,45-50]$. This classification can broadly be compared to the classification of Franklin et al. (2005), where Cyprus type is mafic, Uralian type is bimodal-mafic and Baymak and Rudny Altay types are bimodal-felsic types of deposits [51]. In this paper, we consider examples of weakly metamorphosed deposits of Atlantic, Uralian, Baymak, and Rudny Altay types only, avoiding the complexities of metamorphic overprint. 


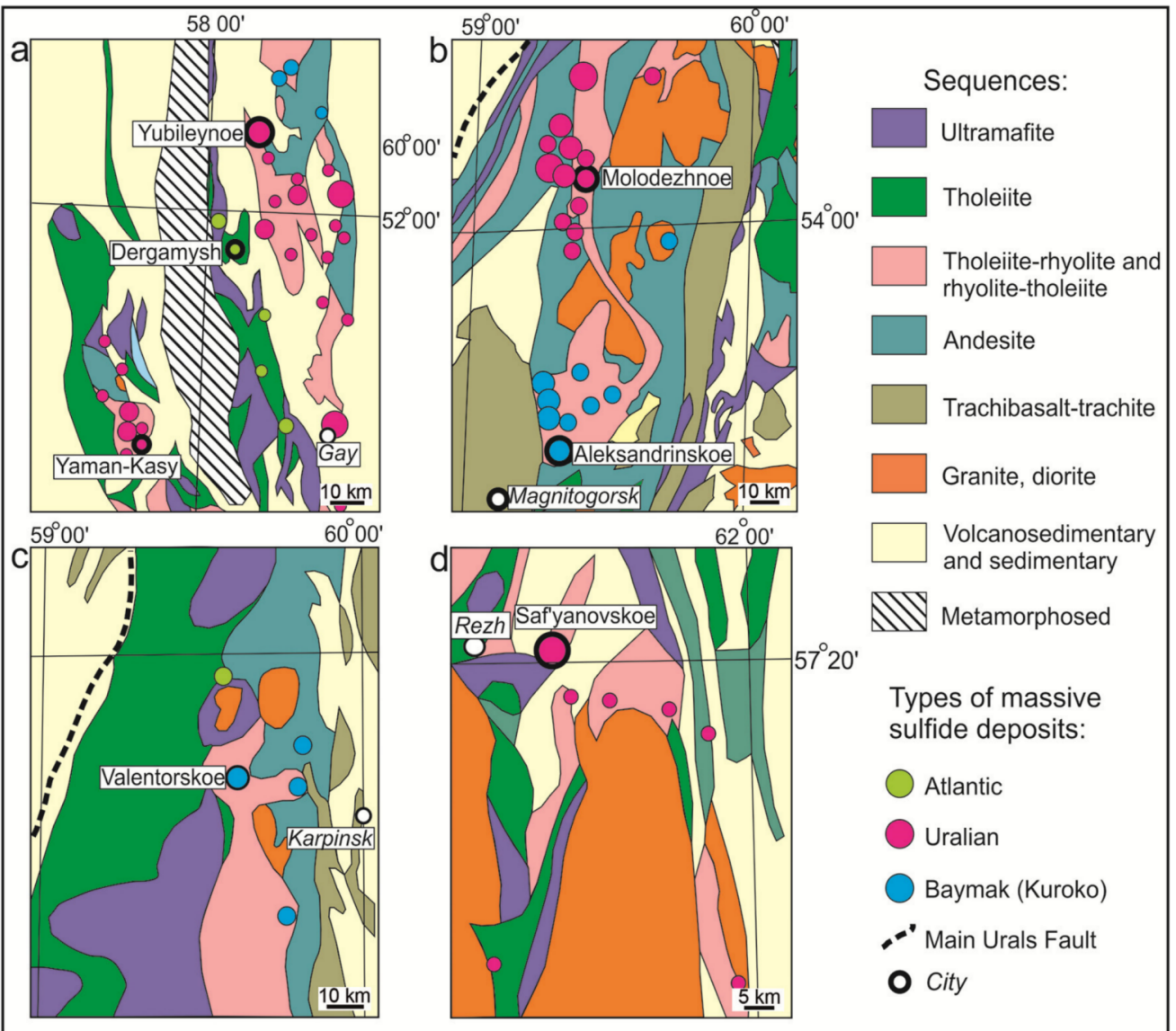

Figure 2. Simplified geological setting of VHMS deposits studied (after unpublished reports of Uralgeologiya).

The Atlantic-type Dergamysh deposit, see Figures 2 and 3, [52] is similar to the ultramafic-hosted hydrothermal sulfide fields of the Atlantic Ocean [53] and is characterized by high $\mathrm{Cu}$ and low $\mathrm{Zn}$ and $\mathrm{Pb}$ contents, higher Co contents, and generally low reserves, see Table 1.

Table 1. Average composition and sizes of the Urals VHMS deposits.

\begin{tabular}{|c|c|c|c|c|c|c|c|c|c|c|}
\hline \multirow{2}{*}{ Deposit } & $\mathrm{Cu}$ & $\mathrm{Zn}$ & $\mathbf{P b}$ & $S$ & Se & $\mathrm{Te}$ & $\mathrm{Au}$ & $\mathrm{Ag}$ & Co & \multirow{2}{*}{$\begin{array}{c}\text { Size } \\
\text { Mt }\end{array}$} \\
\hline & \multicolumn{4}{|c|}{ wt. $\%$} & \multicolumn{5}{|c|}{ ppm } & \\
\hline Dergamysh & 1.3 & 0.3 & $<0.005$ & 47 & 54 & 16 & 2.0 & 12 & $0.01-0.25$ & 1.0 \\
\hline Yubileynoe & 1.4 & 1.0 & $<0.005$ & 43.8 & 50 & 30 & 1.6 & 18 & $<0.01$ & 108.8 \\
\hline Yaman-Kasy & 2.6 & 5.6 & 0.03 & 42.4 & 22 & 325 & 3.3 & 34 & $<0.01$ & 1.7 \\
\hline Molodezhnoe & 2.1 & 3.3 & 0.17 & 29.4 & 82 & 89 & 1.6 & 46 & $<0.01$ & 15.9 \\
\hline Valentorskoe & 6.0 & 3.2 & 0.24 & 17.1 & 22 & 28 & 1.72 & 26 & $<0.01$ & 1.6 \\
\hline Aleksandrinskoe & 2.7 & 4.6 & 0.52 & 27.4 & 8 & 39 & 1.1 & 37 & $<0.01$ & 3.8 \\
\hline Saf'yanovskoe & 2.2 & 0.7 & 0.13 & 25.44 & 60 & 9.2 & 0.5 & 20 & $<0.01$ & 19.4 \\
\hline
\end{tabular}

The data are from unpublished reports of the Ministry of Base Metals, USSR and [18,49].

Three subtypes (U1, U2, U3) are identified as Uralian type based on the $\mathrm{Cu} / \mathrm{Zn}$ ratio of ores, host rock composition and position in the bimodal mafic sequence, see Figure 3. The ore bodies located within or on the basalt basement of the bimodal mafic units represent subtype U1 (Yubileynoe deposit) and the deposits of subtype U2 (Yaman-Kasy) and U3 (Molodezhnoe) are underlain by both basalt and felsic lava flows $[41,47,54]$. The geochemical features of the Yubileynoe deposits are typical both of Cyprus $(\mathrm{Cu} / \mathrm{Zn}>1)$ and Uralian (higher Te contents) types. The highest Te contents and low $\mathrm{Cu} / \mathrm{Zn}$ 
ratio $(<1)$ are characteristic of the deposits of subtypes U2 (Yaman-Kasy) and U3 (Molodezhnoe). In comparison with subtype U2, the U3 subtype ores have higher Pb contents, as shown in Table 1.

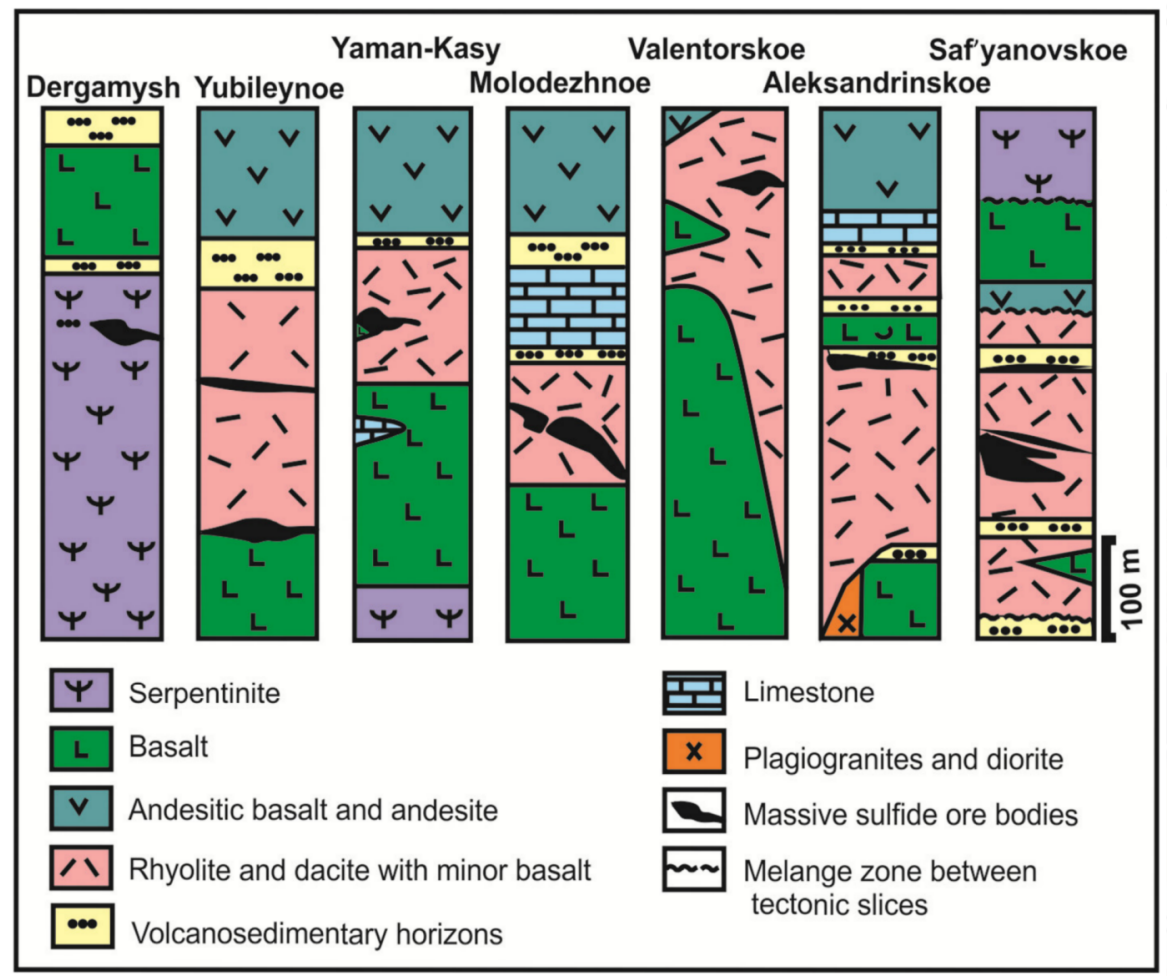

Figure 3. Schematic geological cross-sections of the Urals VHMS deposits studied (modified after [19,45,51]).

Deposits of Baymak type formed in the upper sequences of oceanic rifted arcs [39]. These deposits (Valentorskoe, Aleksandrinskoe) are similar to subtype U3 and occur in the upper ore-bearing levels of the bimodal sequences within the andesitic dacite upper units. Relatively to the Uralian type, the Baymak-type deposits show lower S (<30 wt.\%) and $\mathrm{Te}(<30 \mathrm{ppm}$ ) with higher $\mathrm{Cu}+\mathrm{Zn}$ and $\mathrm{Pb}$ contents. The chimney sulfides of the Baymak-type deposits are characterized by low Co contents in comparison with those from the Uralian type deposits [49]. Baymak-type deposits include two subtypes: B1 ( $\mathrm{Cu}>\mathrm{Zn}$, Valentorskoe) and B2 ( $\mathrm{n}>\mathrm{Cu}$, Aleksandrinskoe), see Table 1. The deposits of Rudny Altay type (Saf'yanovskoe) are similar to the Baymak-type deposits in a geological setting; however, they are associated with black shales in contrast to jaspers in the case of Baymak-type deposits and may conform to the felsic-siliciclastic type described by Franklin et al. (2005) [50].

The Urals deposits described here have been interpreted as variably eroded sulfide mounds [12,17-19,45,55,56], see Figure 4. Their cores are composed of pyrite-rich porous to massive sulfide [57] and lenses of colloform pyrite and marcasite are located in the upper parts of these cores. The cores are surrounded by variable amounts of breccia, successively passing out into sulfide turbidites, sulfide and barite diagenites, and ferruginous sediments [20,58] or, in the case of Saf'yanovskoe, black shales [22].

In general, the studied deposits can be ordered in terms of the increasing amount of felsic volcanic rocks with associated gradual changes in associated ore types: Dergamysh (A) $\rightarrow$ Yubileynoe $(\mathrm{U} 1) \rightarrow$ Yaman-Kasy (U2) $\rightarrow$ Molodezhnoe (U3) $\rightarrow$ Valentorskoe (B1) $\rightarrow$ Aleksandrinskoe (B2). In this progression, the footwall alteration gradually changes from talc-chlorite-carbonate to chlorite, quartz-chlorite-sericite and quartz-sericite rocks. In a similar order, sulfide textures change with a decrease in the occurrences of lattice isocubanite structure, colloform pyrite, pyrrhotite or pseudomorphic pyrite and marcasite after pyrrhotite in the same order. In contrast, the contents of sphalerite-, bornite-, galena- and barite-rich diagenites increases relative to pyrite- and chalcopyrite-rich 
diagenites (with the exception of Valentorskoe). The Saf'yanovskoe deposit $[48,49]$ is an exception as it exhibits features of both the Urals and Baymak deposit types, lacking chalcopyrite-rich diagenites.

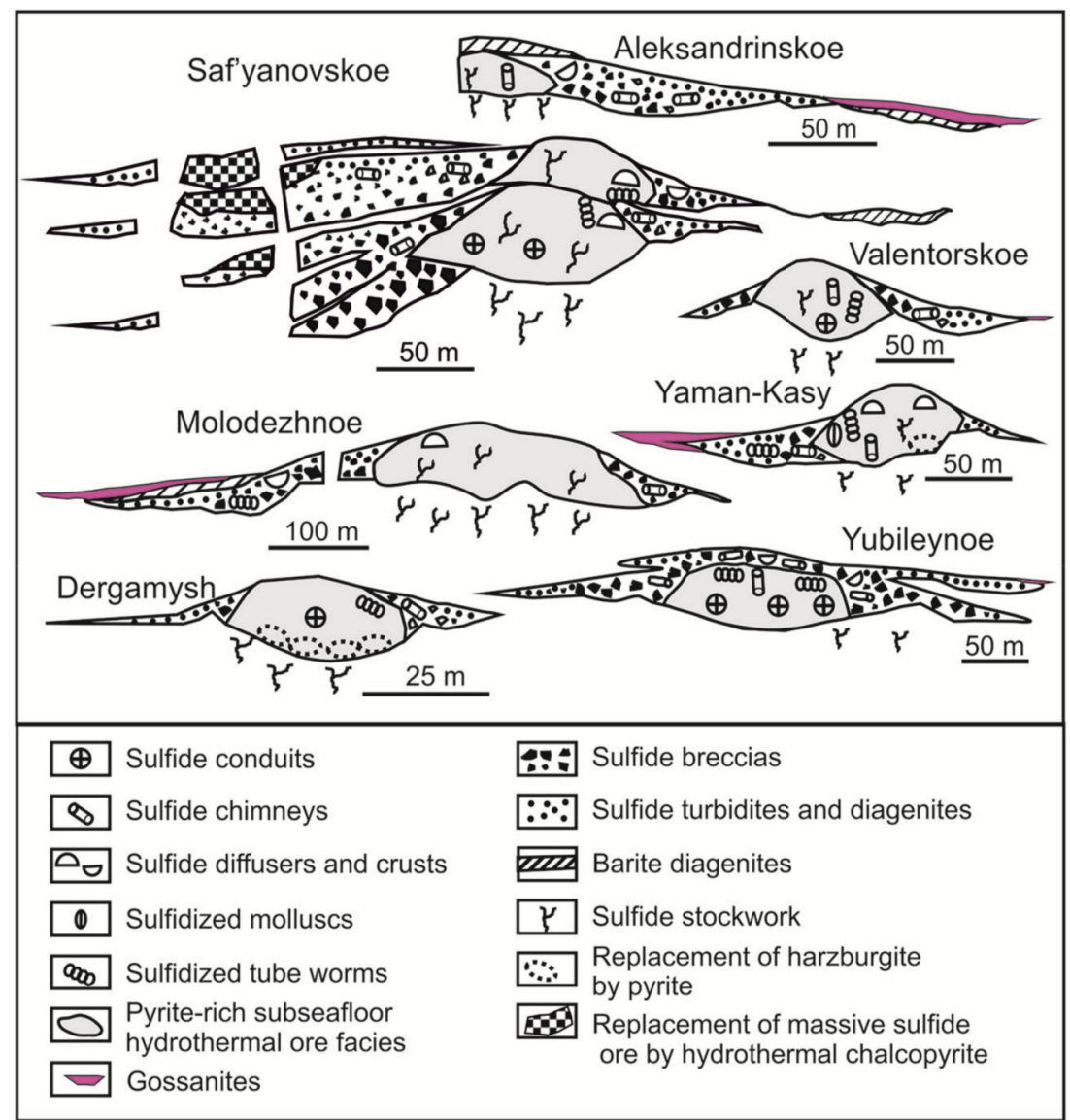

Figure 4. Position of various ore facies, including ore diagenites, in the Urals VHMS deposits.

This range of sulfide types is consistent with similar VHMS deposits found elsewhere $[48,49,59]$. In general, the most diverse mineral assemblages occur in seafloor smoker chimneys (hereafter, chimneys) and clasts of chimneys found in ore diagenites (see below). The chimneys are the most important attributes of the deposit types because they directly reflect the composition of host rocks and the distance from the basalt basement from where the metals venting through the chimneys are sourced [48,49]. In chimneys of the Atlantic-type Dergamysh deposits, mineral assemblages are of low diversity in comparison with other types of deposits. The chimneys of the Uralian-type deposits host abundant tellurides and rare galena, tennantite, tetrahedrite and native gold. The chimneys of the Baymak-type deposits contain lower amounts of telluride minerals and, conversely, more abundant galena and tennantite. The mineral assemblages of chimneys of the Saf'yanovskoe deposit are similar to those of Uralian and Baymak types of the deposits.

Even though deposits are part of the Uralian orogen, the host rocks of the deposits are mostly undeformed and have undergone low metamorphism restricted to zeolite or prehnite-pumpellyite facies $[60,61]$. Primary colloform and framboidal textures, sooty pyrite, sulfidized vent fauna and primary delicate microtextures of chimneys with a well-preserved lattice isocubanite structure and preserved chalcopyrite emulsion ("chalcopyrite decease") in sphalerite and pseudomorphs of sphalerite after würtzite indicate a very low degree of metamorphic overprint $[19,45,48,49,55,62-65]$, accounting for the exceptional degree of preservation of some deposits [36]. In some deposits, ferruginous sediments also record well-preserved primary features consistent with diagenetic and low metamorphic mineral evolution only, showing relict features of neotokite and nambulite [66]. 
Our interpretation is that the mineral assemblages were formed during primary hydrothermal and diagenetic stages including seafloor supergene alteration.

\section{Sampling and Analytical Techniques}

The ore diagenites were mapped in the open pits of the deposits. The hand specimens of ore diagenites were macroscopically studied at the Institute of Mineralogy, Urals Branch, Russian Academy of Sciences (IMin UB RAS, Miass, Russia). The mineralogy of ore diagenites was first studied using an Olympus BX-51 optical microscope at the IMin UB RAS. The chemical composition of minerals was analyzed on a REMMA-202M and Tescan Vega 3sbu SEMs equipped with an Oxford Link EDS and a JXA JEOL 733 (IMin UB RAS) and CAMECA SX-50 and JEOL-JXL-8600 (Natural History Museum, London) and JEOL JXA 8900RL (University of Tasmania, Australia, and Freiberg Mining Academy, Germany) microprobes. For microprobe analyses, the standard deviation of results was less than $0.1 \%$. Major and minor elements were determined at an accelerating potential of $15-25 \mathrm{kV}$, beam current of 20-35 nA and acquisition time between 10 and $20 \mathrm{~s}$ for X-ray peak and background. The effective probe size was 1 to $2 \mu \mathrm{m}$. The following standards were used: $\mathrm{SK} \alpha(\mathrm{ZnS}), \mathrm{AgL} \alpha(\mathrm{Ag}), \mathrm{SbL} \alpha\left(\mathrm{Sb}_{2} \mathrm{~S}_{3}\right)$, $\mathrm{Cd} L \beta(\mathrm{CdS}), \mathrm{Te} L \alpha\left(\mathrm{Bi}_{2} \mathrm{Te}_{3}\right), \mathrm{Te} L b\left(\mathrm{Ag}_{2} \mathrm{Te}\right), \mathrm{SeK} \alpha(\mathrm{PbSe}), \mathrm{Bi} L \alpha\left(\mathrm{Bi}_{2} \mathrm{Te}_{3}\right), \mathrm{Pb} \alpha \alpha(\mathrm{PbS}), \mathrm{CuK} \alpha\left(\mathrm{CuFeS}_{2}\right)$, $\mathrm{SK} \alpha\left(\mathrm{Bi}_{2} \mathrm{~S}_{3}\right), \mathrm{Ag} L \alpha(\mathrm{Ag}), \mathrm{SbL} \alpha\left(\mathrm{Sb}_{2} \mathrm{~S}_{3}\right), \mathrm{Cd} L \alpha(\mathrm{CdTe}), \mathrm{SeK} \alpha\left(\mathrm{Bi}_{2} \mathrm{Se}_{3}\right), \mathrm{Bi} L \alpha\left(\mathrm{Bi}_{2} \mathrm{~S}_{3}\right), \mathrm{HgMa}(\mathrm{HgS}) \mathrm{AsKa}$ $(\mathrm{GaAs}), \mathrm{Cd} \mathrm{La}(\mathrm{CdS}), \mathrm{MnKa}(\mathrm{Mn}), \mathrm{CoKa}(\mathrm{FeCoNi}), \mathrm{TlMa}\left(\mathrm{TlInS}_{2}\right)$. Detection limits were commonly within the following range (wt.\%): $\mathrm{S}$ and $\mathrm{Fe}-0.06, \mathrm{Co}-0.05, \mathrm{Ni}-0.08, \mathrm{Cu}-0.10, \mathrm{Zn}-0.14, \mathrm{As}-0.12$, $\mathrm{Ag}-0.15, \mathrm{Sb}-0.09-0.2, \mathrm{Te}-0.12-0.29, \mathrm{Hg}-0.22, \mathrm{Au}-0.18, \mathrm{~Pb}-0.19-0.34, \mathrm{Bi}-0.18-0.26, \mathrm{Se}-0.1-0.13$, $\mathrm{Sn}-0.03-0.05, \mathrm{Hg}-0.1-0.3, \mathrm{Tl}-0.27, \mathrm{Sn}-0.03, \mathrm{Mn}-0.04$. The chemical compositions of the minerals studied are presented as Supplementary Materials.

The following symbols of minerals are used in the figures below: Alt, altaite; Agl, anglesite; Agy, argyrodite; Ap, apatite; Au, native gold; Bn, bornite; Bnn, bournonite; Brt, barite; Cal, calcite; Car, carrolite; $\mathrm{Cbt}$, cobaltite; Chl, chlorite; Chp, chalcopyrite; $\mathrm{Clr}$, coloradoite; Cls, colusite; $\mathrm{Cv}$, covellite; Cvl, cervelleite; Dg, digenite; Eng, enargite; Gdf, gersdorffite; Gn, galena; Hem, hematite; Hes, hessite; Jrd, jordanite; Kr, kurilite; Mgt, magnetite; Maw, mawsonite; Mkw, mackinawite; Mrc, marcasite; Nc, nickeline; Plb, polybasite; Po, pyrrhotite; Ptz, petzite; Py, pyrite; Qtz, quartz; Ro, roquesite; $\mathrm{Sb}$, native antimony; $\mathrm{Sd}$, siderite; $\mathrm{Srp}$, serpentinite; $\mathrm{Sph}$, sphalerite; $\mathrm{Tb}$, tellurobismuthite; $\mathrm{Tn}$, tennantite; Ttd, tetradymite; Vol, volynskite; Wtz-Sph, sphalerite after würtzite.

\section{Results}

\subsection{Pyrrhotite-Rich Diagenites}

An almost completely altered clastic sulfide layer (pyrrhotite-rich diagenite) mixed with serpentinite fragments was found in the northwest of the Dergamysh deposit, see Figure 5a [52]. This layer is composed of angular pseudomorphic pyrrhotite and chalcopyrite aggregates, which probably replaced pyrite clasts, see Figure $5 b$, and pyrite, see Figure $5 c$, and pyrrhotite-pyrite nodules, see Figure $5 \mathrm{~d}$. Chalcopyrite occurs mostly as anhedral aggregates in the matrix replacing pyrite and pyrrhotite and as veins in pyrrhotite-pyrite nodules.

Numerous lenticular and smoothed angular aggregates of crystalline pyrite from a few hundreds of microns to $3 \mathrm{~mm}$ are similar to nodules characterized by a central porous zone which is surrounded by intergrowths of crystalline pyrite. Some elongated pyrite crystals exhibit typical "pinnate" sector zoning after etching. In many cases, the nuclei of pyrite nodules are replaced by lamellar pyrrhotite crystals and non-opaque minerals with the outer part composed of radial intergrowths of pyrite crystals. Fine pyrite grains and chalcopyrite inclusions are observed in the central parts of the nodules. Fragmented pyrite crystals of the outer zone of the nodules are crossed by pyrrhotite veinlets only a few microns thick. Pyrrhotite also replaces pyrite crystals along the growth zones. The pyrrhotite aggregates contain numerous relict pyrite inclusions and newly formed vein-like, rounded, angular, and flame pentlandite inclusions, which are often associated with non-opaque 
minerals [53]. Mackinawite $\left(\mathrm{Fe}_{7.28} \mathrm{Co}_{0.46} \mathrm{Ni}_{0.29}\right)_{8.03} \mathrm{~S}_{8}$ occurs as lamellae $10 \mu \mathrm{m}$ wide and up to $100 \mu \mathrm{m}$ long in pseudomorphic chalcopyrite probably forming a ghost detrital structure, see Figure 5e.

Nickeline $\left(\mathrm{Ni}_{1.02} \mathrm{Co}_{0.06}\right)_{1.08} \mathrm{As}_{1}$ forms oval, rounded, and triangular grains $10-15 \mu \mathrm{m}$ in size at the contacts of chalcopyrite and pyrrhotite, chalcopyrite and non-opaque minerals. Nickeline grains are often rimmed by gersdorffite $\left(\mathrm{Ni}_{0.55} \mathrm{Co}_{0.40} \mathrm{Fe}_{0.09}\right)_{1.04} \mathrm{As}_{1.02} \mathrm{~S}_{0.98}$, which is intimately intergrown with cobaltite $\left(\mathrm{Co}_{0.69} \mathrm{Ni}_{0.22} \mathrm{Fe}_{0.12}\right)_{1.03} \mathrm{As}_{1.03} \mathrm{~S}_{0.97}$. The latter rims nickeline and also forms anhedral aggregates and veins in chalcopyrite aggregates, see Figure $5 \mathrm{f}$. Small inclusions of pilsenite $\left(\mathrm{Bi}_{4} \mathrm{Te}_{3}\right)$ and native gold were found at the contact of cobaltite and chalcopyrite [53]. Numerous aggregates of sulfides are replaced by the latest newest quartz and magnetite is also a late phase. The primary clastic character of these diagenites is emphasized by the occurrence of numerous chromite clasts as compared with the pyrite-rich core of the main sulfide mound of the deposit [52].

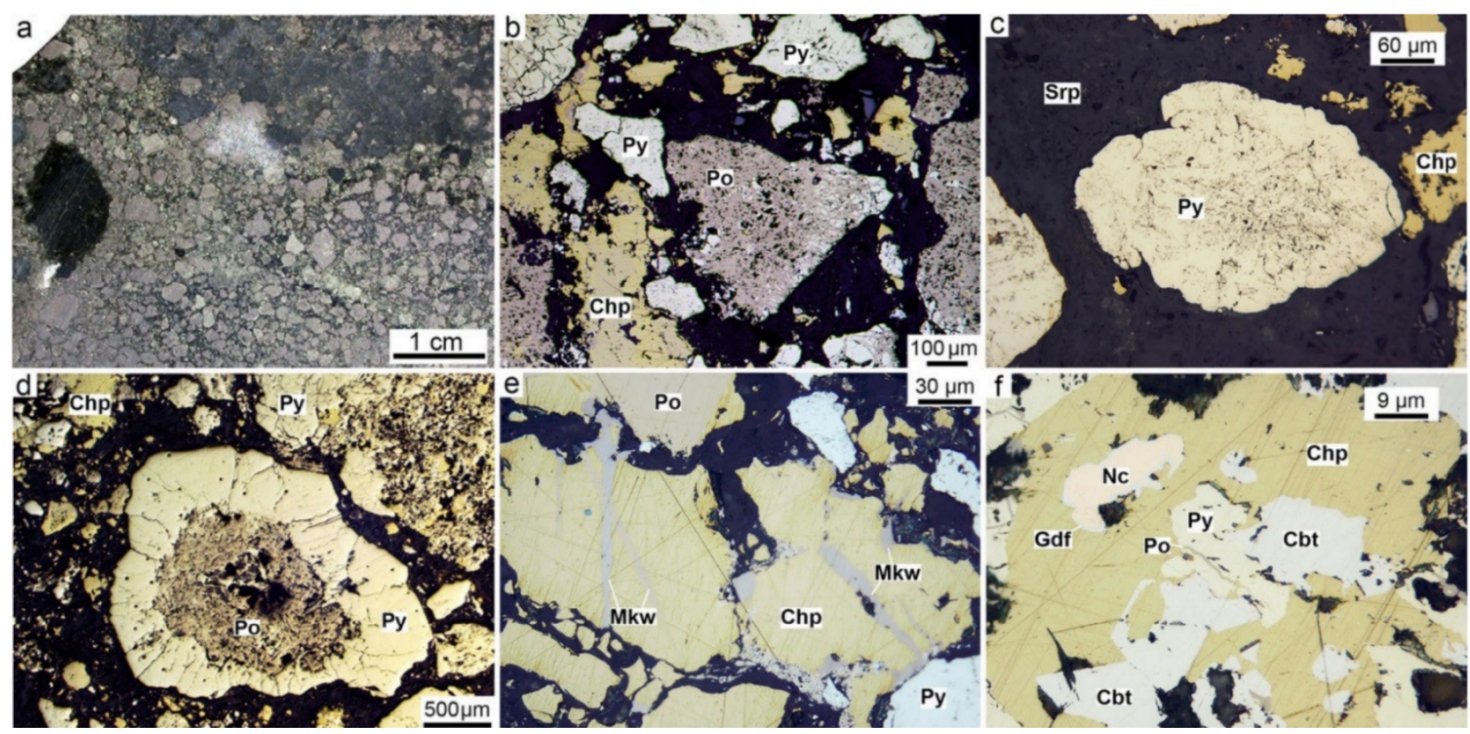

Figure 5. Pyrrhotite-rich diagenite after an altered sulfide sandstone mixed with serpentinite clasts of the Dergamysh deposit: (a) General view; (b) pseudomorphic pyrrhotite and chalcopyrite after ore clasts; (c) pyrite nodule in serpentine; (d) pyrrhotite-pyrite nodule; (e) mackinawite veinlets in anhedral chalcopyrite; (f) nickeline grain rimmed by gersdorffite in anhedral chalcopyrite nearby cobaltite and pyrite crystals. (a) Polished sample, (b-f) reflected light.

\subsection{Chalcopyrite-Rich Diagenites}

Banded chalcopyrite-rich diagenites occur in all types of the deposits studied except for the Saf'yanovskoe deposit. Chalcopyrite-rich diagenites are more abundant in the Atlantic-type deposits as a result of the transformation of sulfide turbidites enriched in chalcopyrite-1-pyrite-sphalerite chimney clasts. The sulfide turbidites of the Dergamysh deposit contain striking chalcopyrite nodules developed around serpentinite cores, see Figure 6a.

The degree of the replacement increases to the upper part of the turbidite rhythms indicating progressive seafloor alteration (early diagenesis), see Figure 6b. The diagenites typically preserve relict clastic microtextures of pyrite. Authigenic chalcopyrite (chalcopyrite-2) replaces clasts of pyrite, see Figure $6 c$, and reniform sphalerite-1 forms after suspected würtzite, see Figure 6d. Strongly altered sulfide turbidites are mostly composed of chalcopyrite-2 and -3. Authigenic inclusions of native gold $\mathrm{Ag}_{0.54} \mathrm{Au}_{0.46}$ occur in the replacement fronts and in pyrite nodules. The cores of radial columnar marcasite nodules are replaced by chalcopyrite-2 as well, see Figure 6e. Chalcopyrite-3 hosts mackinawite inclusions. Carrolite is found in the zoned pyrite crystals replaced by chalcopyrite-2, see Figure $6 \mathrm{f}$, and shows variable substitution of $2 \mathrm{Co}^{2+}$ for $\left(\mathrm{Cu}^{+}+\mathrm{Fe}^{3+}\right)$, leading to a gradual isomorphic range of non-stochiometric minerals: $\mathrm{Cu}_{0.76}\left(\mathrm{Co}_{2.02} \mathrm{Fe}_{0.27} \mathrm{Ni}_{0.23}\right)_{2.52} \mathrm{~S}_{4} \rightarrow \mathrm{Cu}_{0.77}\left(\mathrm{Co}_{2.14} \mathrm{Fe}_{0.38} \mathrm{Ni}_{0.15}\right)_{2.67} \mathrm{~S}_{4}$. Serpentinite cores are crossed cut by veinlets of a Ni-bearing (up to $0.4 \mathrm{wt} \% \mathrm{Ni}$ ) phase of 
intermediate composition between cattierite and pyrite $\left(\mathrm{Co}_{0.5} \mathrm{Fe}_{0.5}\right) \mathrm{S}_{2}$ hosting inclusions of cobaltite $\left(\mathrm{Co}_{0.88} \mathrm{Fe}_{0.07} \mathrm{Cu}_{0.03} \mathrm{Ni}_{0.01}\right) \mathrm{As}_{1.01} \mathrm{~S}$, see Figure $6 \mathrm{~g}$. Interstitial latest-stage magnetite crystals occur in chalcopyrite-2,3 aggregates.
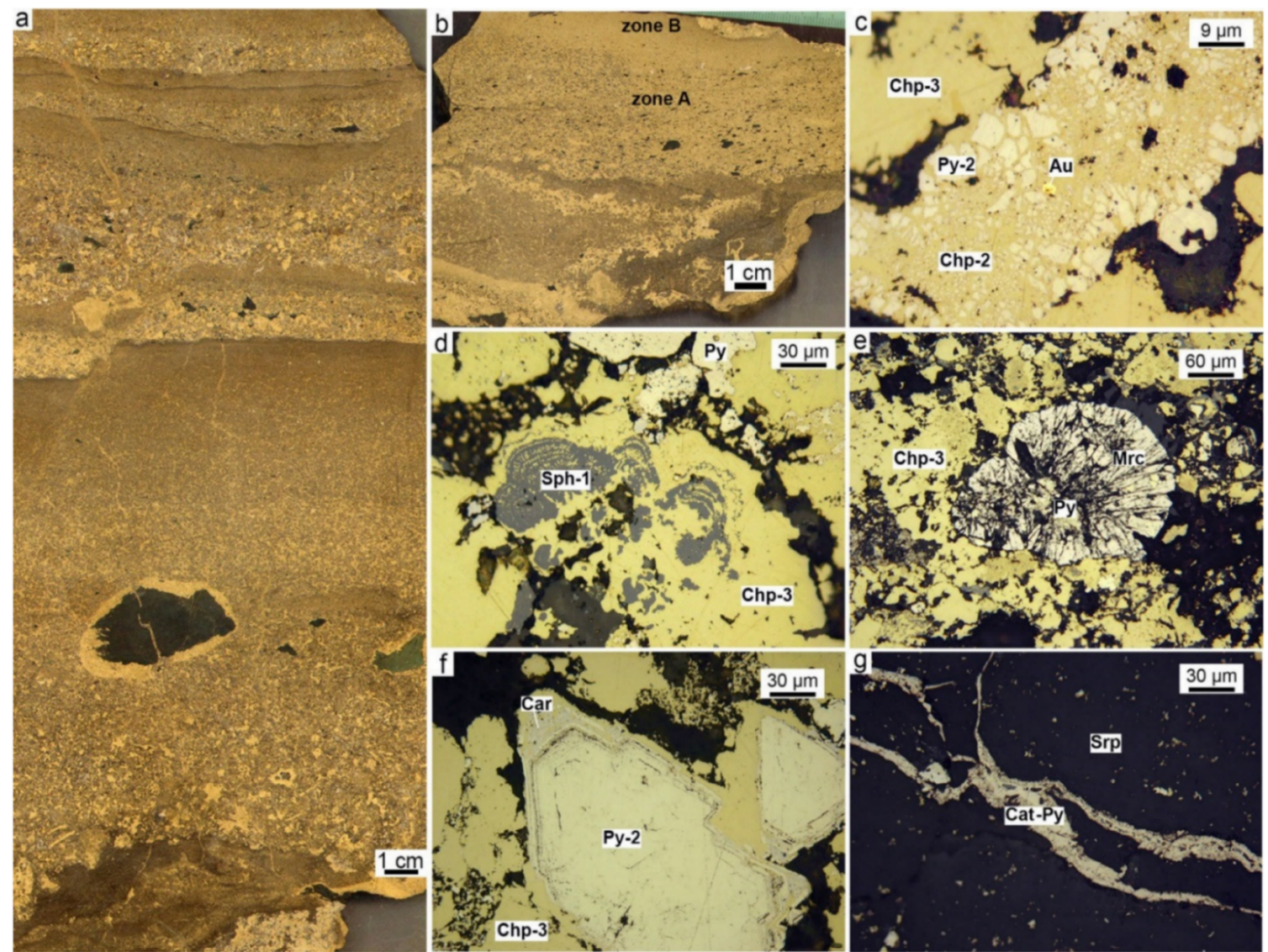

Figure 6. Mineralogical features of chalcopyrite-rich diagenites of the Dergamysh deposit: (a) Chalcopyrite nodules with serpentinite cores in sulfide turbidite; (b) chalcopyrite-rich diagenites enriched in fine-grained chalcopyrite in the upper part of the rhythms (zone B) and relict pyrite and serpentinite (black) clasts in the lower part (zone A); (c) authigenic native gold in chalcopyrite- 2 replacing pyrite fragments; (d) replacement of sphalerite clasts by chalcopyrite-2; (e) radial columnar marcasite nodule in chalcopyrite-2; (f) replacement of euhedral zonal pyrite crystal by chalcopyrite-2 and carrollite ( $\mathrm{g}$ ) veinlets of a phase of intermediate composition between cattierite and pyrite (Cat-Py) with inclusions of cobaltite in the serpentine core of the chalcopyrite nodule; $(\mathbf{a}, \mathbf{b})$ Polished sample, (c-g) reflected light.

In the Yubileynoe deposit, chalcopyrite-rich layers are intercalated with pyrite-rich diagenites containing partly preserved pyrite clasts [67]. The adjacent layers are characterized by different degrees of replacement, see Figure 7a. Chalcopyrite takes the form of a number of generations. Chalcopyrite-1 occurs in hydrothermal chimney clasts. Fine-grained chalcopyrite-2 replaces pyrite clasts, see Figure $7 \mathrm{~b}$. Some veinlets and pores are then filled by coarser-grained chalcopyrite-3, seemingly free of relict pyrite. Rare growth twins of chalcopyrite-3 are observed after etching. Pyrite nodules occur in some of the chalcopyrite-rich layers and their cores are replaced by chalcopyrite- 3 and sphalerite-2,3, as shown in Figure 7c. Chalcopyrite-3 and sphalerite-3 locally contain inclusions of native gold, $\mathrm{Au}_{0.70} \mathrm{Ag}_{0.30}$, see Figure $7 \mathrm{~d}$. In some pyrite clasts, interstitial chalcopyrite-3 veinlets are hosts to abundant authigenic coloradoite, see Figure 7e, rare tellurobismuthite, altaite, rucklidgeite, stützite, and volynskite. It is suggested that the formation of authigenic tellurides and native gold occurred during seafloor dissolution (halmyrolysis) of colloform pyrite and fragments of crystalline chalcopyrite-1 and sphalerite-1, which are found to be enriched in Te only in fragments formed in black or gray smoker 
chimneys. No tellurides and native gold are observed in the latest coarse-grained chalcopyrite-4, which shows elongated deformed glide twins recognized after etching [67]. Chalcopyrite-4 most likely formed in quartz veinlets linked to weak deformation or metamorphism.

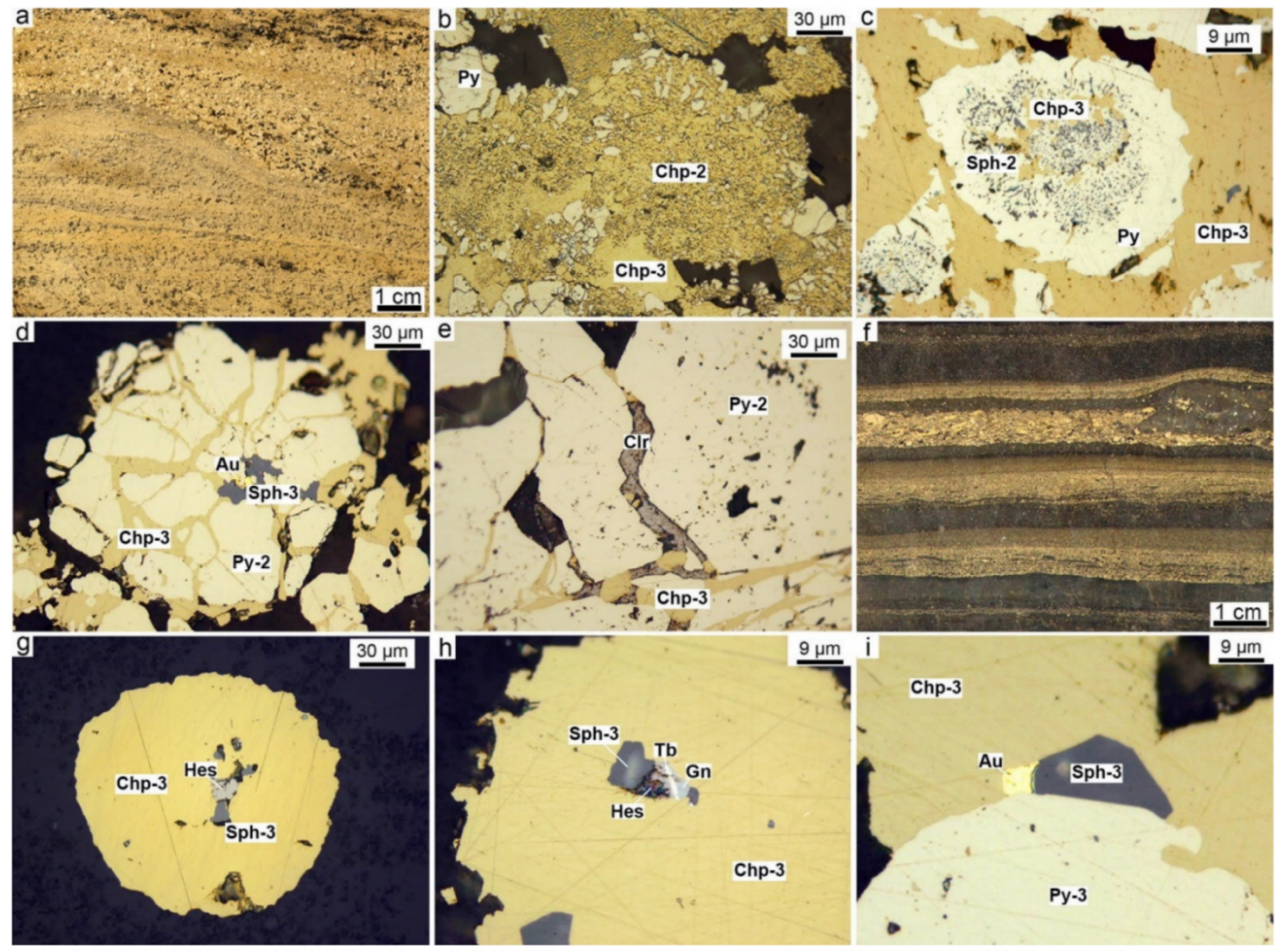

Figure 7. Mineralogical features of chalcopyrite-rich diagenite of the Yubileynoe deposit: (a) Chalcopyrite-rich layers with disseminated pyrite; (b) fine- and coarse-grained chalcopyrite-2 and -3 with relict pyrite clasts after etching in $\mathrm{HNO}_{3}$; (c) pyrite nodule with a core partly replaced by sphalerite-2 and chalcopyrite-3; (d) chalcopyrite-3 and sphalerite-3 with native gold partly replacing coarse-grained pyrite; (e) coloradoite and chalcopyrite-3 veinlets in pyrite; (f) sulfide turbidites intercalated with hyaloclastic shales; (g) inclusions of sphalerite-3, hessite and galena in the core of chalcopyrite-3 nodule; (h) inclusions of sphalerite-3, galena, hessite and tellurobismuthite in the chalcopyrite-3 nodule; (i) intergrowth of native gold and pyrite- 3 and sphalerite-3 in chalcopyrite- 3 nodule. (a,f) Polished sample, (b-e,g-k) reflected light.

In volcano-sedimentary units contemporaneous with sulfide venting at the Yubileynoe deposit, rounded and lens-shaped coarser crystalline chalcopyrite- 3 nodules are disseminated through hyaloclastic shales intercalated with sulfide turbidites, see Figure 7f. The core of these nodules host inclusions of Se-bearing galena, hessite and sphalerite-3, see Figure 7g, and a phase of intermediate composition between tellurobismuthite and kawazulite $\mathrm{Bi}_{1.96} \mathrm{Ag}_{0.26} \mathrm{Te}_{2.75} \mathrm{Se}_{0.25}$ that is intergrown with hessite, galena and sphalerite-3, see Figure $7 \mathrm{~h}$. Native gold $\mathrm{Au}_{0.77} \mathrm{Ag}_{0.21} \mathrm{Hg}_{0.02}$ is associated with pyrite- 3 and sphalerite-3 inside the chalcopyrite-3 nodule, see Figure 7 i.

In the Yaman-Kasy deposit, thin layers of chalcopyrite-rich diagenites are mostly intercalated with ferruginous gossanites or chloritized hyaloclastic shale in a layered clastic sulfide member of the southern flank of the ore body, see Figure 8a. Authigenic chalcopyrite-2 pseudomorphs colloform, framboidal, biomorphic and granular pyrite, marcasite and sphalerite clasts in the upper part of the turbidite rhythms [22]. Lattice textures after isocubanite, emulsion and colloform textures within primary hydrothermal clasts are almost completely overprinted in the altered sulfide layers. In some 
diagenites, early replacement of pyrite and sphalerite clasts by chalcopyrite- 2 remains in thin sulfide layers, see Figure $8 \boldsymbol{b}$, while later replacement of pyrite clasts and tubes worms by chalcopyrite- 2 and -3 is observed in diagenites, see Figure $8 \mathrm{c}$. Clastic pyrite is successively replaced by chalcopyrite, hematite and Fe-rich chlorite, as shown in Figure 8d. Chalcopyrite-rich diagenites contain galena, native tellurium, native gold $\mathrm{Au}_{0.71} \mathrm{Ag}_{0.27} \mathrm{Hg}_{0.02}$, hessite, calaverite, arsenopyrite, magnetite, hematite and bornite, which mostly occur at the replacement front. The microtextures of these minerals show them to be authigenic versus their syngenetic counterparts in chimneys $[19,22,68]$. Small inclusions of Se-bearing altaite (up to $0.9 \mathrm{wt} . \% \mathrm{Se}$ ) occur with Se-rich galena (up to $6.4 \mathrm{wt} . \% \mathrm{Se}$ ), disseminated in authigenic chalcopyrite-sphalerite aggregates, which in turn are partly replaced by Fe-rich chlorite, as shown in Figure 8e. In chalcopyrite-2,3 aggregates, exotic small round inclusions of apparently native antimony were found for the first time in the Urals deposits, see Figure 8f.
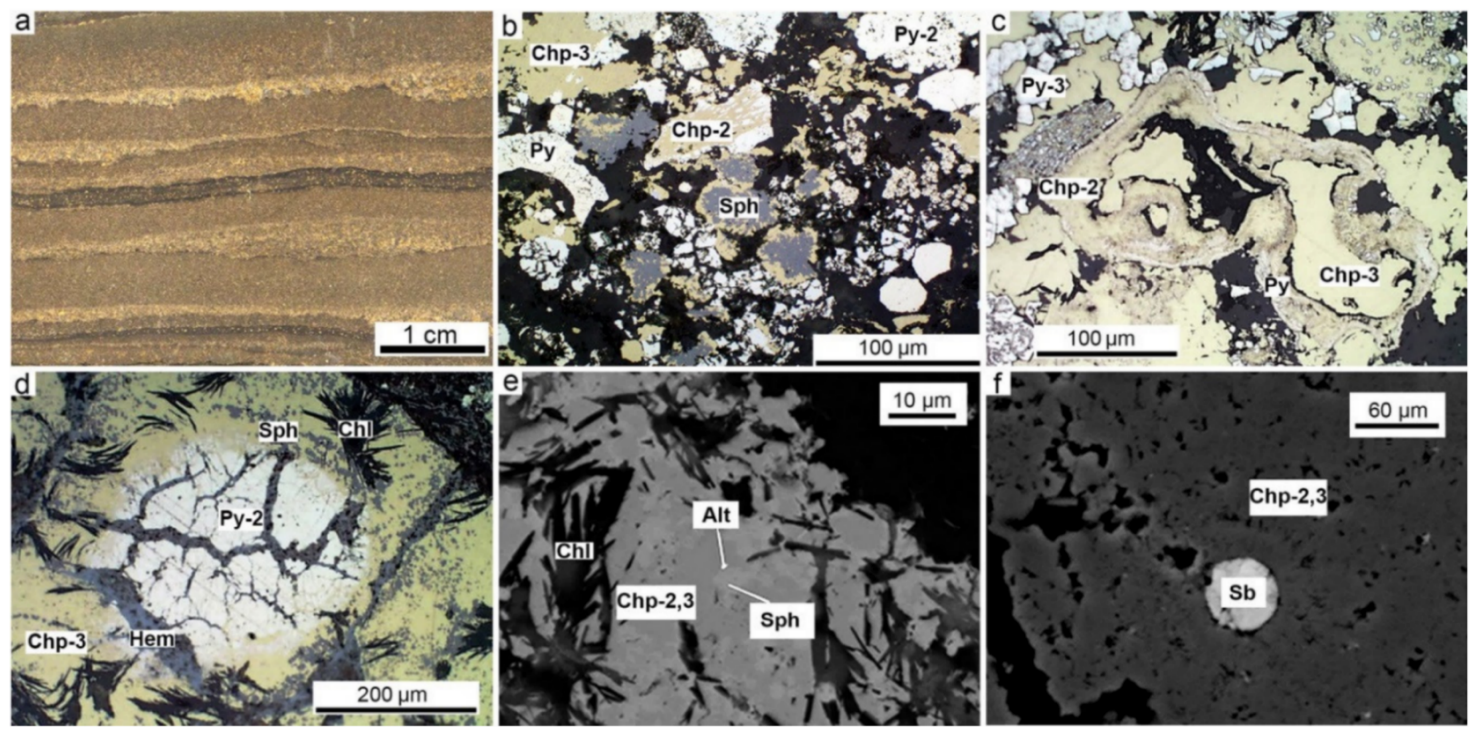

Figure 8. Mineralogical features of chalcopyrite-rich diagenites of the Yaman-Kasy deposit: (a) General view; (b) immature replacement of pyrite and sphalerite clasts by chalcopyrite-2; (c) mature replacement of pyrite clast and vestimentifera tube by chalcopyrite- 2 and -3 ; (d) replacement of pyrite clast by chalcopyrite followed by hematite and chlorite; (e) inclusion of altaite in chalcopyrite-2,3 with relict sphalerite replaced by chlorite; (f) native antimony inclusion in chalcopyrite-2,3. (a) Polished sample, (b-d) reflected light, (e,f) back-scattered electron (BSE) images.

In the Molodezhnoe deposit, chalcopyrite-rich diagenites occur in the upper parts of the turbidite rhythmic layers or are intercalated with pyrite- and sphalerite-rich diagenites, see Figure 9a,b, on the flanks of the ore body. In some of the diagenites, chalcopyrite-2,3 intergrown with sphalerite-2,3 contains relict pyrite clasts. Tennantite and galena are ubiquitous authigenic minerals, which are mostly associated with sphalerite-2,3. Hessite and altaite inclusions occur in Te-bearing tennantite $\mathrm{Cu}_{9.66}\left(\mathrm{Zn}_{1.47} \mathrm{Fe}_{0.36}\right)_{1.85}\left(\mathrm{As}_{3.71} \mathrm{Sb}_{0.61} \mathrm{Te}_{0.03}\right)_{4.45} \mathrm{~S}_{13.16}$ and Se-bearing galena (up to $1.5 \mathrm{wt} . \% \mathrm{Se}$ ) veinlets, see Figure $9 \mathrm{c}-\mathrm{e}$. This mineral assemblage is characterized by the presence of Se-rich minerals: Naumannite $\mathrm{Ag}_{2} \mathrm{Se}$, bohdanowiczite $\mathrm{Ag}_{1.08} \mathrm{Bi}_{1.04} \mathrm{Se}_{2.00}$, and $\mathrm{Ag}$-bearing clausthalite $\mathrm{PbSe}$ (up to 6 wt.\% Ag) associated with kurilite $\mathrm{Ag}_{8.00}\left(\mathrm{Se}_{2.84} \mathrm{Te}_{1.16}\right)_{4.00}$, see Figure $9 \mathrm{f}$, and roquesite $\left(\mathrm{Cu}_{1.02} \mathrm{In}_{0.98} \mathrm{Fe}_{0.07}\right)_{2.07}\left(\mathrm{~S}_{1.86} \mathrm{Se}_{0.14}\right)_{2.00}$, see Figure 9g [58]. The Bi-bearing (up to $1.98 \mathrm{wt}$.\% Bi) tennantite $\mathrm{Cu}_{9.62}\left(\mathrm{Zn}_{1.49} \mathrm{Fe}_{0.36}\right)_{1.84}\left(\mathrm{As}_{3.73} \mathrm{Sb}_{0.49} \mathrm{Bi}_{0.14}\right)_{4.36} \mathrm{~S}_{13.16}$ occurs in chalcopyrite-3 and is intergrown with hessite, coloradoite, petzite, galena, and sphalerite, see Figure $9 \mathrm{~h}$. Abundant grains of native gold $\mathrm{Au}_{0.75} \mathrm{Ag}_{0.25}$ are associated with hessite inclusions [58]. Chalcopyrite-3, hessite and altaite are replaced by chlorite, as shown in Figure 9i. 

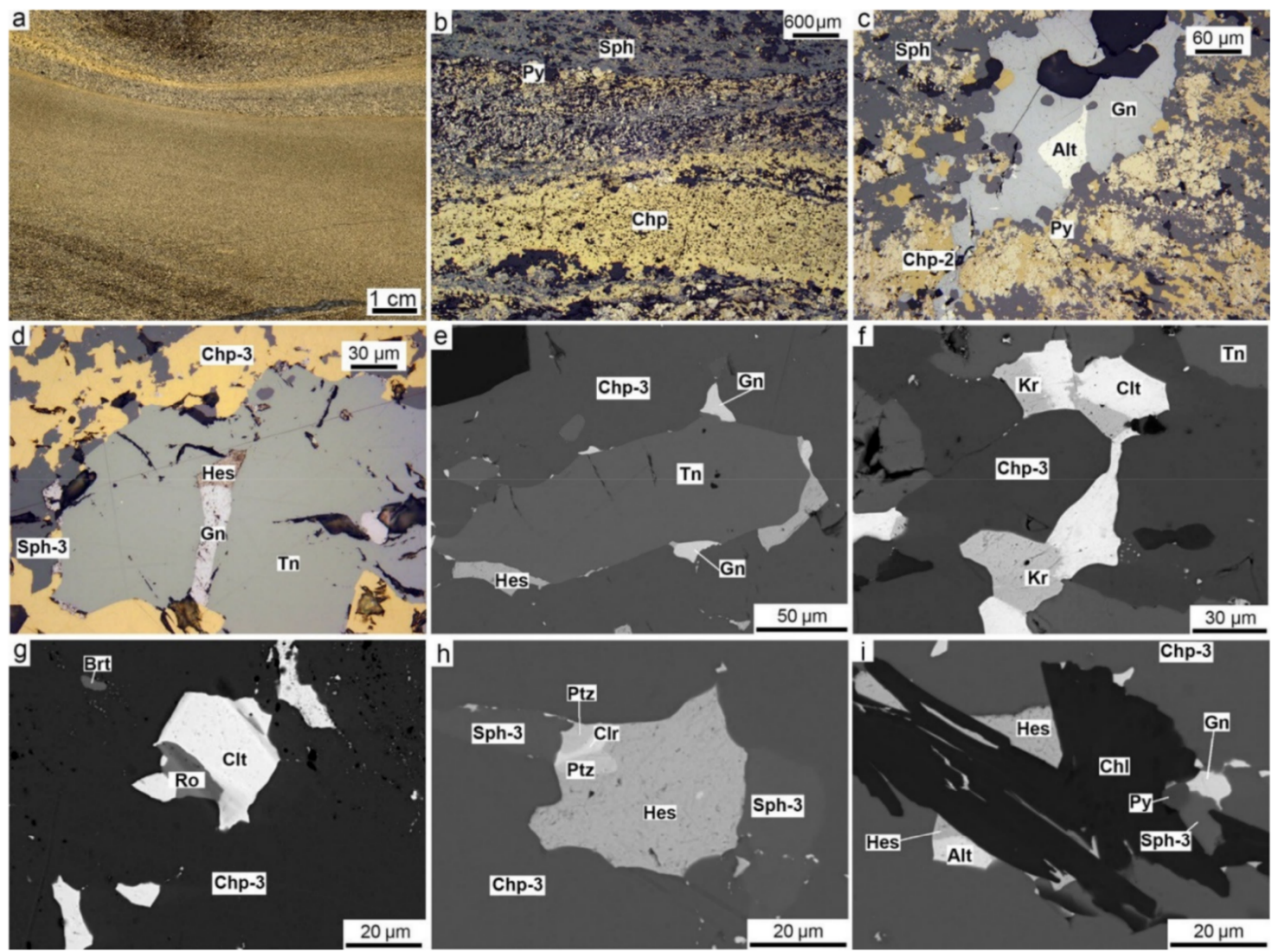

Figure 9. Mineralogical features of chalcopyrite-rich diagenites of the Molodezhnoe deposit: (a) Chalcopyrite-rich diagenites in sulfide turbidites; (b) intercalation of chalcopyrite- and sphalerite-rich diagenites; (c) altaite inclusion in galena veinlet; $(\mathbf{d}, \mathbf{e})$ intergrowth of hessite, galena and tennantite in chalcopyrite-3 and sphalerite-3; (f) clausthalite and kurilite in authigenic chalcopyrite-3; (g) clausthalite and roquesite in chalcopyrite- 3 ; (h) assemblage of hessite, coloradoite, petzite, and sphalerite- 3 in chalcopyrite-3; (i) replacement of chalcopyrite-3, hessite and altaite by chlorite. (a) Polished sample; (b-d) reflected light; (e-i) BSE photo.

In the Valentorskoe deposit, alternation of chalcopyrite- and sphalerite-rich diagenites is common for the upper part of the flank of the ore body, see Figure 10a. Although sulfide breccias containing chimney clasts are well preserved, thin layers of fine-clastic sulfide turbidites clearly show strong alteration. Pyrite clasts show replacement by chalcopyrite, sphalerite and bornite, see Figure 10b. The diagenites also contain inclusions of Ag-bearing wittichenite $\left(\mathrm{Cu}_{2.81} \mathrm{Ag}_{0.18}\right)_{2.99} \mathrm{Bi}_{0.99}\left(\mathrm{~S}_{2.96} \mathrm{Se}_{0.06}\right)_{3.02}$. The successive replacement of chalcopyrite and sphalerite layers by bornite, galena, and tennantite is a common feature of these diagenites, see Figure 10c.

In the Aleksandrinskoe deposit, chalcopyrite-rich layers are intercalated with sphalerite-rich diagenites, see Figure 10d. Colloform pyrite clasts are replaced by chalcopyrite- 2 and -3 , tennantite- 2 and galena-2. Porous aggregates of galena- 2 and chalcopyrite- 2 are replaced by chalcopyrite-3, see Figure 10 e. Low-fineness native gold $\mathrm{Au}_{0.66} \mathrm{Ag}_{0.34}$ occurs in the replacement fronts in this assemblage. Intergrowths of chalcopyrite- 3 , galena- 3 and sphalerite- 3 are common for more mature diagenites. Crystalline chalcopyrite- 3 cements relict pyrite crystals together with galena- 3 and Te-Se-bearing tennantite $\mathrm{Cu}_{9.45}\left(\mathrm{Fe}_{0.3} \mathrm{Zn}_{2.13}\right)_{2.33}\left(\mathrm{As}_{3.44} \mathrm{Sb}_{0.33} \mathrm{Te}_{0.03} \mathrm{Se}_{0.03}\right)_{3.83} \mathrm{~S}_{13}$, see Figure 10f. 


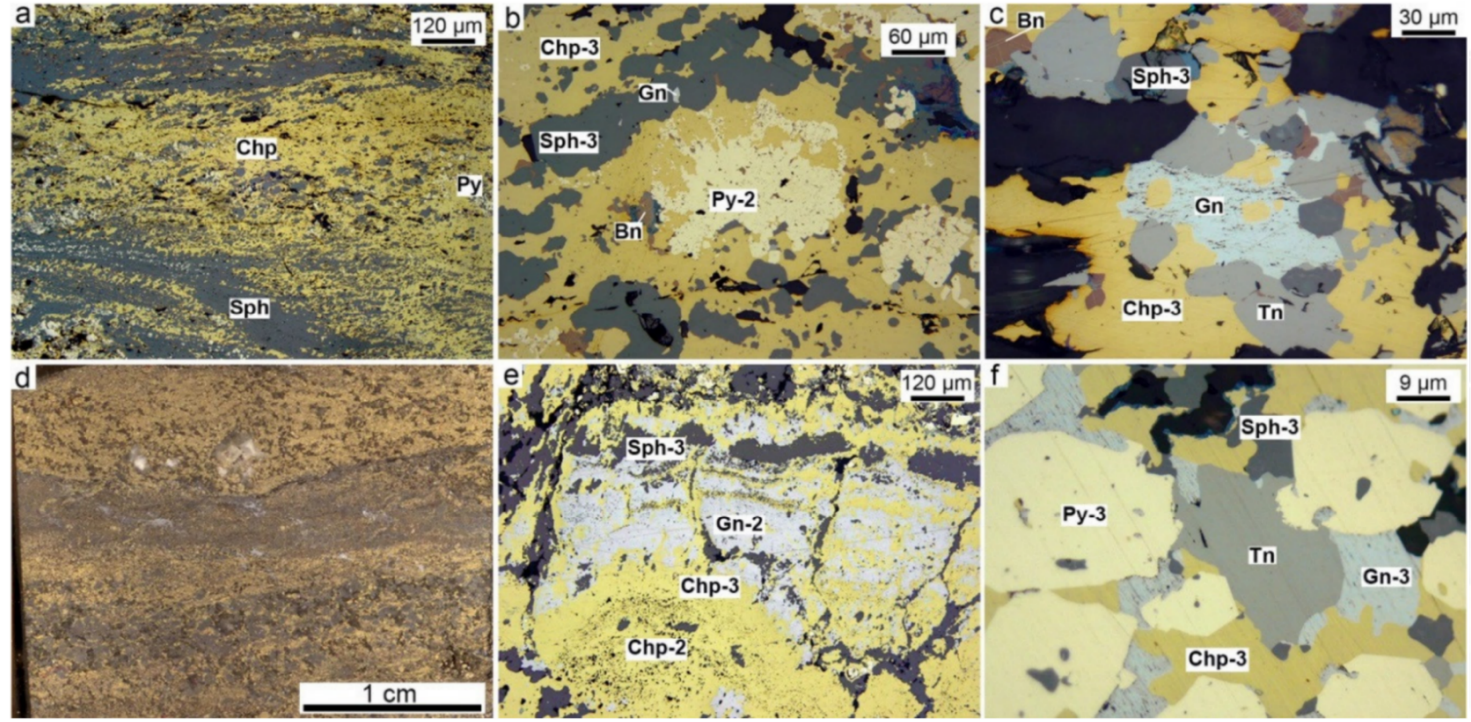

Figure 10. Mineralogical features of chalcopyrite-rich diagenites of the Valentorskoe (a-c) and Aleksandrinskoe (d-f) deposits: (a) Intercalation of chalcopyrite- and sphalerite-rich diagenites; (b) replacement of pyrite clasts by chalcopyrite, bornite and sphalerite; (c) galena-tennantitesphalerite-bornite assemblage in chalcopyrite (black, quartz and chlorite); (d) alternation of chalcopyrite- and sphalerite-rich diagenites; (e) replacement of galena-2 by chalcopyrite-3 in pseudomorphic chalcopyrite-2 after colloform pyrite; (f) pyrite-3, galena-3 and tennantite in chalcopyrite-3. (a,d) Polished sample; (b,c,e,f) reflected light.

\subsection{Bornite-Rich Diagenites}

Bornite-rich diagenites are typical of massive sulfide bodies of the Uralian- and Baymak-type deposits. In the Atlantic-type Dergamysh, Uralian-type Yaman-Kasy and Rudny Altay-type Saf'yanovskoe deposits, bornite is found as isolated inclusions while in the Uralian-type Yubileynoe deposit, some bornite-rich bands and spots are observed in chalcopyrite chimney breccias.

Pyrite, chalcopyrite, galena, and tennantite are subordinate minerals of bornite-rich diagenites. $\mathrm{Zn}$-rich tennantite $\mathrm{Cu}_{10.35}\left(\mathrm{Zn}_{1.48} \mathrm{Fe}_{0.11} \mathrm{Mn}_{0.02}\right)_{1.61}\left(\mathrm{As}_{3.51} \mathrm{Sb}_{0.30} \mathrm{Te}_{0.19}\right)_{4.00} \mathrm{~S}_{13.00}$ is characterized by higher Te contents (up to $1.5 \mathrm{wt} . \%$ ). The clasts of pyrite-1,2 are replaced by bornite, see Figure 11a, and extremely small colusite inclusions $(1-2 \mu \mathrm{m})$ are disseminated around relict pyrite, see Figure $11 \mathrm{~b}$. Locally, bornite can replace chalcopyrite. An assemblage of native gold $\mathrm{Au}_{0.59} \mathrm{Ag}_{0.41}$, digenite, and galena occurs in the replacement front. Hessite intergrown with both galena and chalcopyrite can be found in bornite and hessite inclusions are overgrown or replaced by cervelleite, see Figure 11c. A mineral similar to cervelleite $\left(\mathrm{Ag}_{3.06} \mathrm{Cu}_{1.02}\right)_{4.08} \mathrm{Te}_{1.00} \mathrm{~S}_{1.11}$ is also found as fine (3-6 $\left.\mu \mathrm{m}\right)$ grains. Like cervelleite from other deposits, the example here exhibits a deficit of $\mathrm{Ag}^{+}$, which is compensated by $\mathrm{Cu}^{+}[69]$. 


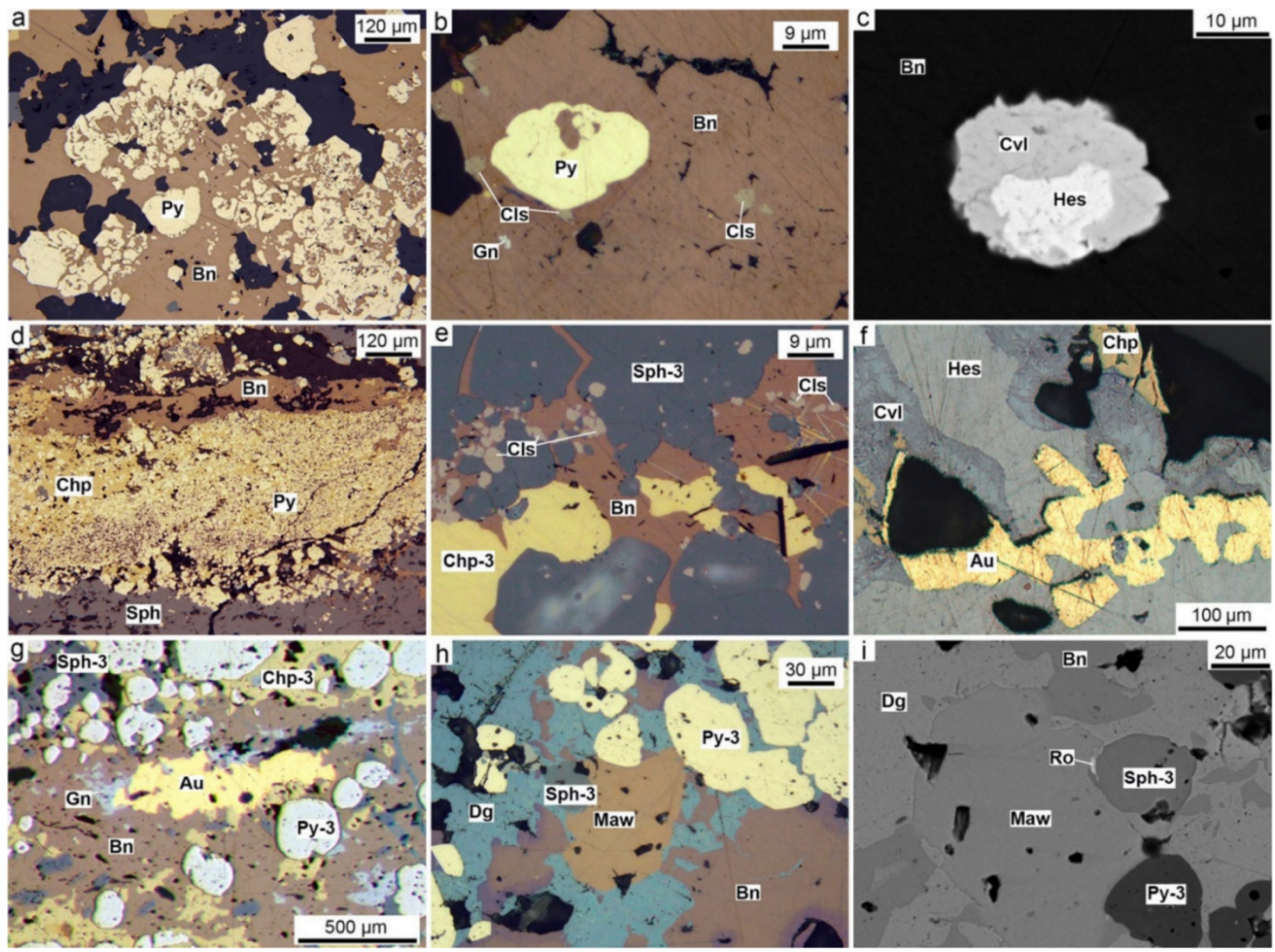

Figure 11. Mineralogical features of bornite-rich diagenites of the Yubileynoe $(\mathbf{a}-\mathbf{c})$, Valentorskoe $(\mathbf{d}-\mathbf{f})$ and Aleksandrinskoe (g-i) deposits: (a) Bornite with relict pyrite; (b) bornite with authigenic inclusions colusite; (c) rim of cervelleite around hessite; (d) bornite-rich diagenite in the upper part of the graded pyrite-chalcopyrite turbidite layer; (e) colusite in bornite, sphalerite-3 and chalcopyrite-3; (f) native gold and hessite replaced by cervelleite; (g) native gold and galena in bornite layer; (h) mawsonite in bornite-digenite assemblage; (i) roquesite inclusions in assemblage with mawsonite, digenite, sphalerite-3, and relict pyrite in bornite. $(\mathbf{a}-\mathbf{b}, \mathbf{d}-\mathbf{h})$ Reflected light, $(\mathbf{c}, \mathbf{i})$ SEM photo.

In the Molodezhnoe deposit, bornite-rich diagenites appear as $\mathrm{Cu}$-enrichment facies of the submarine supergene zone lying below a barite-pyrite gossanous and leached zone [12]. Bornite forms veinlents, matrix and bands in chalcopyrite-pyrite breccias. Bornite also replaces pyrite and chalcopyrite. Diverse rare mineral assemblages are formed at the replacement front. Numerous rare minerals including stromeyerite, arsenosulvanite, jalpaite, mackinstryite, stannoidite, mawsonite, enargite, and Ge-bearing sulvanite (Ge $0.23 \mathrm{wt} . \%)$ have been found in bornite-rich ores $[45,70,71]$. Tellurium-bearing tennantite $\mathrm{Cu}_{12.23}\left(\mathrm{Fe}_{0.3} \mathrm{Zn}_{0.48}\right)_{0.78}\left(\mathrm{As}_{3.56} \mathrm{Sb}_{0.16} \mathrm{Te}_{0.44}\right)_{4.16} \mathrm{~S}_{13}$ occurs as a subordinate phase. Abundant inclusions of native gold $\mathrm{Au}_{0.66} \mathrm{Ag}_{0.34}$ are typical of the bornite-rich assemblage [18, 19,40 ] and very rare, low-fineness electrum $\mathrm{Au}_{0.59} \mathrm{Ag}_{0.41}$ occurs in association with barite.

In the Valentorskoe deposit, bornite-rich diagenites are intercalated with pyrite- and sphalerite-rich diagenites. The bornite-rich diagenites are locally observed in the upper part of the graded pyrite-chalcopyrite turbidite layers, see Figure 11d, and relict corroded grains of pyrite- 2 are replaced by bornite. Bornite is then replaced by digenite and, locally, by lattice-textured chalcopyrite- 4 . Relict sphalerite-3, pyrite- 2 and chalcopyrite- 3 are found in bornite as well as common colusite [71]. Colusite shows variable $\mathrm{Cu}$ contents between $\mathrm{Cu}_{23.38} \mathrm{~V}_{1.81}\left(\mathrm{As}_{3.44} \mathrm{Ge}_{1.35} \mathrm{Sn}_{0.82}\right)\left(\mathrm{Zn}_{2.48} \mathrm{Fe}_{0.26}\right) \mathrm{S}_{32.47}$ and $\mathrm{Cu}_{26.12} \mathrm{~V}_{2.09}\left(\mathrm{As}_{4.05} \mathrm{Ge}_{1.03} \mathrm{Sn}_{0.87}\right) \mathrm{Fe}_{0.50} \mathrm{~S}_{31.34}$ and is found with galena in the replacement front where sphalerite-3 and chalcopyrite- 3 are replaced by bornite, see Figure 11e.

The composition of subordinate fahlores varies from Te-tennantite $\left(\mathrm{Cu}_{11.04} \mathrm{Ag}_{0.10}\right)_{11.14}$ $\left(\mathrm{Zn}_{0.39} \mathrm{Fe}_{0.02}\right)_{0.41}\left(\mathrm{As}_{2.41} \mathrm{Te}_{1.31} \mathrm{Bi}_{0.07} \mathrm{Sb}_{0.07}\right)_{3.86}\left(\mathrm{~S}_{12.98} \mathrm{Se}_{0.02}\right)_{13.00}$ to goldfieldite $\left(\mathrm{Cu}_{11.85} \mathrm{Ag}_{0.08}\right)_{11.93}$ 
$\left(\mathrm{Fe}_{0.03} \mathrm{Zn}_{0.01}\right)_{0.04}\left(\mathrm{Te}_{2.13} \mathrm{As}_{1.72} \mathrm{Bi}_{0.05} \mathrm{Sb}_{0.0 .05}\right)_{3.95}\left(\mathrm{~S}_{12.96} \mathrm{Se}_{0.04}\right)_{13}$. Both are enriched in $\mathrm{Bi}^{3+}$ and depleted in $\mathrm{Zn}^{2+}$ and $\mathrm{Fe}^{2+}$ in comparison with stoichiometric tennantite. $\mathrm{Fe}^{2}+$ and $\mathrm{Zn}^{2}+$ substitute for $\mathrm{Cu}^{+}$with increasing $\mathrm{Te}^{4+}$ and there is inverse correlation between $\left(\mathrm{Fe}^{2+}+\mathrm{Zn}^{2+}\right)$ and $\mathrm{Te}^{4+}[48,72]$.

In bornite-rich diagenites, wittichenite $\left(\mathrm{Cu}_{2.88} \mathrm{Ag}_{0.03}\right)_{2.91} \mathrm{Fe}_{0.08} \mathrm{Bi}_{1.01} \mathrm{~S}_{3}$ contains low Fe and $\mathrm{Ag}$ contents. Hessite is partly replaced by cervelleite $\left(\mathrm{Ag}_{3.5} \mathrm{Cu}_{0.5}\right)_{4} \mathrm{TeS}$ in assemblage with abundant native gold $\mathrm{Au}_{0.62} \mathrm{Ag}_{0.36} \mathrm{Hg}_{0.02}$, see Figure 11f. Digenite and magnetite form late minerals.

In the Aleksandrinskoe deposit, some clastic sulfide layers are partly replaced by bornite. Stratified bornite layers occupy several (two to three) lithological-stratigraphical levels marking each halmyrolysis cycle [73]. In sulfide turbidites, bornite-rich layers occur in the upper part of every rhythm [19]. In these bornite-rich diagenites, pyrite clasts are replaced by bornite and later diagenite with the formation of galena and large grains of native gold $\mathrm{Au}_{0.90} \mathrm{Ag}_{0.10}$, see Figure $11 \mathrm{~g}$. Stromeyerite $\mathrm{Ag}_{0.99} \mathrm{Cu}_{0.99} \mathrm{~S}_{1.02}$ is also a typical mineral of the bornite-rich submarine supergene zone [73]. Inclusions of Te-bearing (up to 4.9 wt.\% Te) $\mathrm{Zn}$-rich tennantite $(\mathrm{Cu})_{10.00}\left(\mathrm{Zn}_{1.30} \mathrm{Fe}_{0.03}\right)_{1.33}\left(\mathrm{As}_{3.42} \mathrm{Te}_{0.52} \mathrm{Sb}_{0.43}\right)_{4.37} \mathrm{~S}_{13.00}$ are abundant in bornite. Some grains of this tennantite have higher Bi contents (up to $3.6 \mathrm{wt} . \%$ ). The maximum Bi contents (up to $5 \mathrm{wt} . \%$ ) are detected in some Te-rich tennantite of the deposit [74]. A renierite-like mineral $\mathrm{Cu}_{19.66}\left(\mathrm{Zn}_{0.73} \mathrm{Cu}_{1.18}\right)_{1.91}\left(\mathrm{Ge}_{2.63} \mathrm{AsFe}_{7.86}\right) \mathrm{S}_{32.76}$ was previously found in bornite-rich ores at the deposit $[71,73,75]$ along with abundant mawsonite $\mathrm{Cu}_{6.11} \mathrm{Fe}_{2.02} \mathrm{Sn}_{0.97} \mathrm{~S}_{7.90}$, see Figure $11 \mathrm{~h}$, and tiny grains $(\sim 2 \mu \mathrm{m})$ of rare germanite-like mineral $\mathrm{Cu}_{25.14}\left(\mathrm{Ge}_{2.25} \mathrm{As}_{1.44} \mathrm{Sb}_{0.35}\right) \mathrm{Fe}_{6.79} \mathrm{~S}_{29.7}$. Small inclusions of a roquesite-like mineral $\mathrm{Cu}_{1.23} \mathrm{In}_{0.76} \mathrm{Fe}_{0.05} \mathrm{~S}_{1.96}$ occur at the contact between mawsonite and sphalerite-3 grains, as shown in Figure 11i.

\subsection{Sphalerite-Rich Diagenites}

In the Yubileynoe deposit, sphalerite-rich diagenites are rare, undoubtedly due to the low $\mathrm{Zn}$ content of the primary ores. Locally, sulfide breccias contain clasts of sphalerite-1-rich chimneys, which may be considered white or clear smoker analogs [48]. Thin sphalerite layers can be found in banded pyrite- and chalcopyrite-rich diagenites, see Figure 12a. Porous sphalerite-rich lenses are the residues of sphalerite layers replaced by chalcopyrite, see Figure 12b. Sphalerite-2 displays a microgranular structure following etching by $\mathrm{HNO}_{3}+\mathrm{CaF}_{2}$ while sphalerite- 3 crystals exhibit twinning. Some sphalerite-3 aggregates contain galena inclusions, see Figure 12c. Tennantite $\mathrm{Cu}_{9.44}\left(\mathrm{Zn}_{1.35} \mathrm{Fe}_{0.59}\right)_{1.93}\left(\mathrm{As}_{3.02} \mathrm{Sb}_{0.92}\right)_{3.94} \mathrm{~S}_{13}$ occur at the contacts between sphalerite-3 and chalcopyrite-3.

No sphalerite-rich diagenites were found in the Yaman-Kasy deposit in contrast to post-sedimentary sphalerite in some sulfide turbidite layers. Fine-grained sphalerite-2 replaces radial pyrite clasts, see Figure 12d. Sphalerite-2 replaces clasts of hydrothermal sphalerite-1, which is characterized by a subhedral hexagonal morphology typical of pseudomorph after würtzite. Zoning of sphalerite- 1 crystals is emphasized by epitaxial chalcopyrite. In comparison with sphalerite-2, sphalerite-3 exhibits coarser crystals and twins, see Figure 12e. Relict chalcopyrite in sphalerite- 3 is rare, see Figure 12f. The sequence of mineral formation of the Yaman-Kasy turbidites is as follows: pyrrhotite- $1 \rightarrow$ sooty pyrite- $1 \rightarrow$ marcasite $\rightarrow$ euhedral pyrite- $3 \rightarrow$ chalcopyrite- $2 \rightarrow$ sphalerite- $2 \rightarrow$ chalcopyrite-3 $\rightarrow$ sphalerite-3 $\rightarrow$ hematite.

In the Molodezhnoe deposit, sphalerite-rich diagenites are intercalated with pyrite- and chalcopyrite-rich diagenites at the flanks of the ore body, see Figure 12g. Pyrite clasts are replaced by sphalerite- 2 . Thin pyrite-rich diagenites are completely replaced by sphalerite- 3 or chalcopyrite- 3 leading to the formation of sphalerite or chalcopyrite diagenites, see Figure 12h. In some cases, stratified tennantite occurs at the contact between sphalerite and chalcopyrite layers. This $\mathrm{Zn}$-rich tennantite $\mathrm{Cu}_{9.69}\left(\mathrm{Zn}_{1.50} \mathrm{Fe}_{0.34}\right)_{1.84}\left(\mathrm{As}_{3.63} \mathrm{Sb}_{0.58} \mathrm{Bi}_{0.09}\right)_{4.30} \mathrm{~S}_{13.16}$ contains up to $1.29 \mathrm{wt}$ \% Bi. Relict pyrite nodules can be found in some sphalerite layers. The fine-grained cores of the nodules are replaced by galena and sphalerite-3. Altaite is associated with galena inclusions, see Figure 12i. Galena contains Se (up to $0.8 \mathrm{wt} . \%$ ). Barite crystals are disseminated in sphalerite-3. 


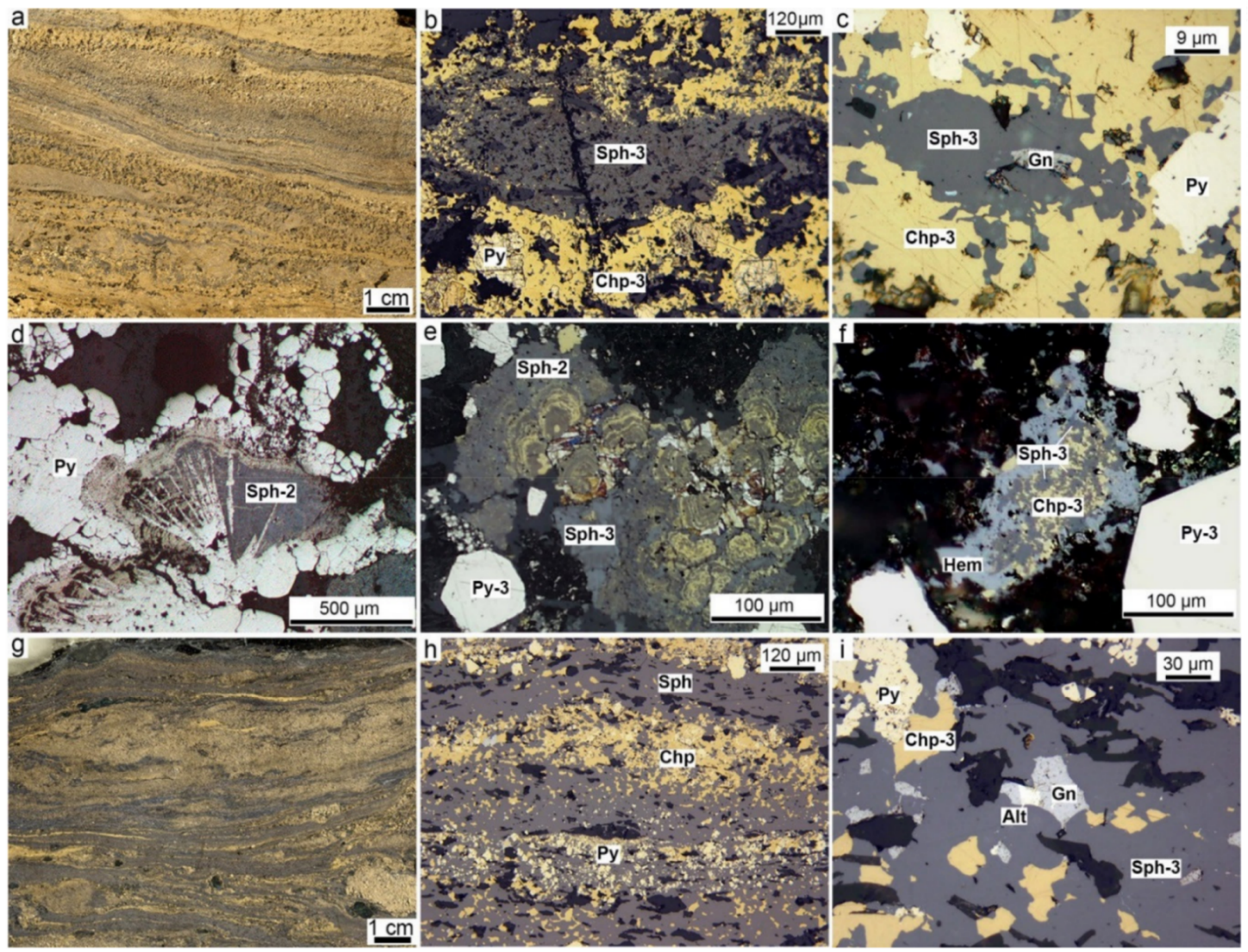

Figure 12. Mineral features of sphalerite-rich diagenites of the Yubileynoe (a-c), Yaman-Kasy (d-f), and Molodezhnoe (g-i) deposits: (a) Alternating sphalerite- and chalcopyrite-rich diagenites; (b) porous sphalerite-rich layer; (c) galena inclusion in sphalerite-3; (d) replacement of radial pyrite by sphalerite-2; (e) replacement of chalcopyrite-sphalerite clast by sphalerite-2 and sphalerite-3; (f) successive replacement of chalcopyrite- 3 by sphalerite- 3 and hematite in assemblage with euhedral pyrite-3 in hematite-quartz aggregates; (g) sphalerite-rich diagenites intercalated with pyrite- and chalcopyrite-rich diagenites; (h) intercalation of sphalerite- and chalcopyrite-rich diagenites; (i) galena and altaite inclusions in sphalerite-rich diagenite. (a,g) Polished sample, $(\mathbf{b}-\mathbf{f}, \mathbf{h}-\mathbf{i})$ reflected light.

In the Valentorskoe deposit, sphalerite-rich diagenites are intercalated with chalcopyrite-rich diagenites, see Figure 13a. Sphalerite-rich diagenites contain inclusions of Te- and Bi-bearing $\mathrm{Zn}$-rich tennantite $\mathrm{Cu}_{10.81}\left(\mathrm{Zn}_{1.25}\right)_{1.25}\left(\mathrm{As}_{2.68} \mathrm{Te}_{0.90} \mathrm{Sb}_{0.48} \mathrm{Bi}_{0.11) 4.17} \mathrm{~S}_{12.77}\right.$ and bornite, see Figure $13 \mathrm{~b}$. Altaite-galena-anglesite assemblage is associated with tennantite, see Figure $13 \mathrm{c}$.

Sphalerite-rich diagenites are abundant in the Aleksandrinskoe deposit, in particular, at the flank of the ore body and are interbanded with chalcopyrite-, pyrite- or barite-rich diagenites and cherts, see Figure 13d. Relict zonal pyrite-2, as well as later azonal pyrite-3, is replaced by sphalerite-3, see Figure 13e. In some cases, numerous galena-3 grains are observed in sphalerite-rich diagenites alternating with cherts, as shown in Figure 13f. Zinc-rich tennantite $\mathrm{Cu}_{10.4}\left(\mathrm{Zn}_{1.79} \mathrm{Fe}_{0.02}\right)_{1.81}$ $\left(\mathrm{As}_{3.45} \mathrm{Sb}_{0.39} \mathrm{Te}_{0.05}\right)_{3.89} \mathrm{~S}_{12.9}$ occurs in minor amounts. The composition of gold varies from $\mathrm{Au}_{0.76} \mathrm{Ag}_{0.24}$ to $\mathrm{Au}_{0.63} \mathrm{Ag}_{0.37}$.

In the Saf'yanovskoe deposit, intercalation of coarse- and fine-grained sphalerite layers inside the diagenites confirms syngenetic recrystallization conditions, see Figure $13 \mathrm{~g}$. Sphalerite-2 replaces colloform pyrite, while crystalline pyrite remains unaltered, see Figure 13h. Previously, Ag-rich gold $\mathrm{Ag}_{0.70} \mathrm{Au}_{0.30}$, tennantite, enargite, bornite, galena, Ag-rich (to $4.8 \mathrm{wt} \% \mathrm{Ag}$ ) and $\mathrm{Sb}$-rich tetrahedrite (up to $28.3 \mathrm{wt}$ \% Sb), acanthite, sternbergite were found in the assemblage with authigenic sphalerite-3 [22,76,77]. In sphalerite-3, enargite appears instead of chalcopyrite associated with argyrodite $\mathrm{Ag}_{8} \mathrm{GeS}_{6}$, see Figure 13i. 

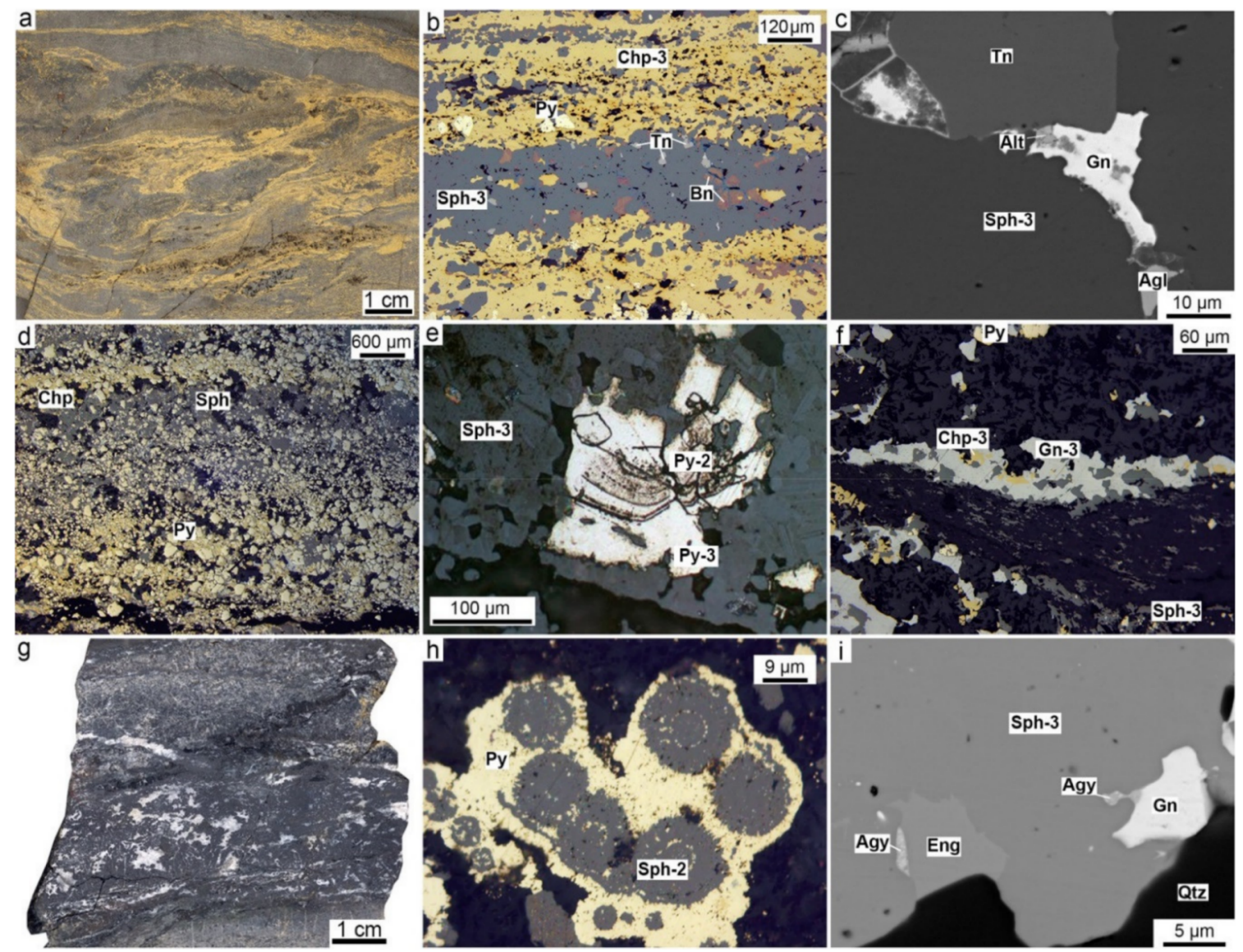

Figure 13. Mineralogical features of sphalerite-rich diagenite of the Valentorskoe $(\mathbf{a}-\mathbf{c})$, Aleksandrinskoe (d-f), and Saf'yanovskoe (g-i) deposits: (a) Intercalation of sphalerite-rich and chalcopyrite-rich diagenites with slamping texture; (b) a more detailed view of the previous photo; (c) tennantite and galena in assemblage with altaite and anglesite in sphalerite-3; (d) sphalerite in the upper part of the pyrite-chalcopyrite turbidite; (e) relict pyrite-2 clast overgrown by pyrite-3 in sphalerite-3; (f) lenses of galena-3, sphalerite-3, and chalcopyrite-3 in chert; (g) sphalerite-rich diagenites with barite (white) crowned by gray cherts; (h) selective replacement of colloform pyrite by sphalerite-2; (i) argyrodite in assemblage with galena and enargite in sphalerite-3. (a,g) Polished sample, $(\mathbf{b}, \mathbf{d}-\mathbf{f}, \mathbf{h})$ reflected light, (c,i) SEM photo.

\subsection{Pyrite-Rich Diagenites}

Pyrite-rich diagenites often occur far from the core of the deposit that represents the hydrothermal refining zone, and it is concluded that they are a product of seafloor supergene $\mathrm{Cu}-\mathrm{Zn}$ leaching from sulfide turbidites. The corrosive microtextures of colloform pyrite, marcasite, chalcopyrite and sphalerite in some clastic sulfide layers accompanied by recrystallization of pyrite are evidence of these processes. Different degrees of recrystallization of colloform pyrite, marcasite and zonal subhedral pyrite to anzonal euhedral pyrite in the adjacent layers of sulfide turbidites are a signature of the diagenetic versus metamorphic or hydrothermal origin of these processes [19].

In the Dergamysh deposit, the pyrite-rich diagenites are intercalated with pyrite-sphalerite turbidites, see Figure 14a. The turbidites are composed of pyrite-2 clasts in assemblage with clasts of colloform crystalline pyrite. Rare zoned sphalerite- 1 clasts are characterized by chalcopyrite emulsion and hexagonal forms typical of former würtzite. Relict sphalerite- 1 can be found in authigenic pyrite- 3 . In many places, pyrite framboids and their nodular aggregates are enclosed in euhedral azoned pyrite-3, see Figure 14b. Numerous fine-grained nodules are abundant in pyrite-rich diagenites, see Figure 14c. Relict zoned pyrite-2 composes the cores of pyrite-3 aggregates, see Figure 14d. 
In the Yubileynoe deposit, pyrite-rich diagenites are intercalated with hyaloclastic shales, see Figure 14e. Less altered pyrite turbidites contain relict zoned pyrite-2 in euhedral pyrite-3, see Figure 14f, and framboidal pyrite nodules, see Figure $14 \mathrm{~g}$. Ore clasts mixed with fine-grained hyaloclastic material are completely transformed to fine-grained pyrite nodules and later euhedral pyrite-3, see Figure 14h. Their core consists of abundant relict chlorite and illite, see Figure 14h, and rare pyrrhotite, chalcopyrite-3 and sphalerite-3 [67]. The coarse-grained pyrite-3 rim hosts inclusions of petzite, hessite and native gold, see Figure 14 i.

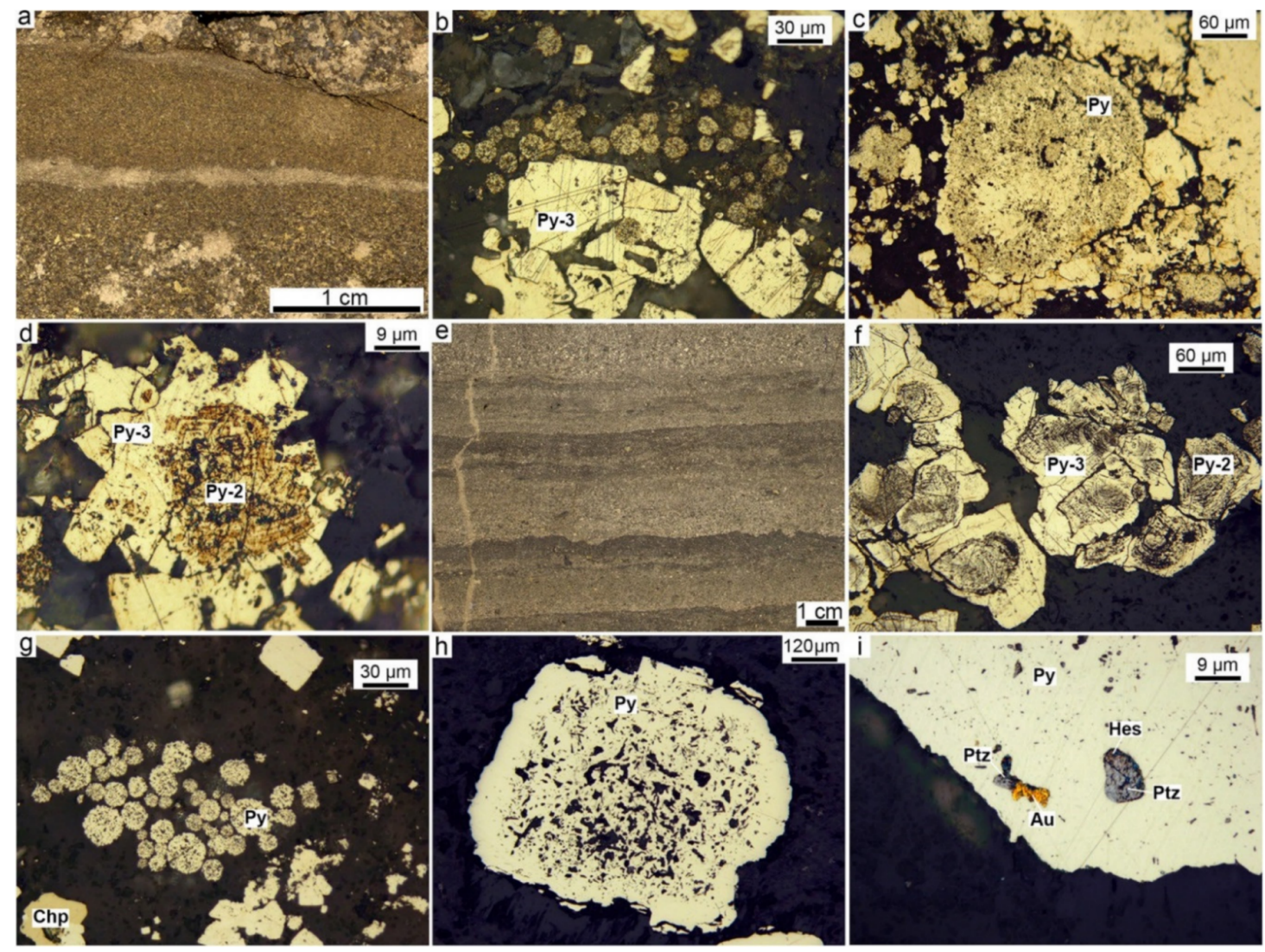

Figure 14. Mineralogical features of pyrite-rich diagenites of the Dergamysh (a-d) and Yubileynoe (e-i) deposits: (a) Pyrite-rich diagenites in sphalerite-pyrite turbidites; $(\mathbf{b}, \mathbf{c})$ nodules of framboidal (b) and fine-grained (c) pyrite; (d) relict zoned crystal of pyrite-2 with a rim of subhedral pyrite-3; (e) altered pyrite turbidites intercalated with hyaloclastic shales; (f) rims of pyrite-3 around zoned pyrite-2 fragments; (g) nodule of framboidal pyrite; (h) pyrite nodule; (i) hessite, petzite and native gold in a rim of pyrite nodule. (a,e) Polished sample; (b-d,f-i) reflected light.

No pyrite-rich diagenites were found in sulfide turbidites of the Yaman-Kasy deposit. Signatures of pyrite-3, however, can be recognized in some sulfide turbidite layers containing clasts of colloform pyrite or pseudomorphic sooty pyrite. Colloform pyrite is overgrown by subhedral pyrite-3, see Figure 15a. Pseudomorphic pyrite after euhedral hydrothermal pyrrhotite is replaced by anhedral pyrite- 3 or marcasite, see Figure 15b. These immature sequences at Yaman-Kasy, probably represent the initial stage of the formation of pyrite-rich diagenites. 


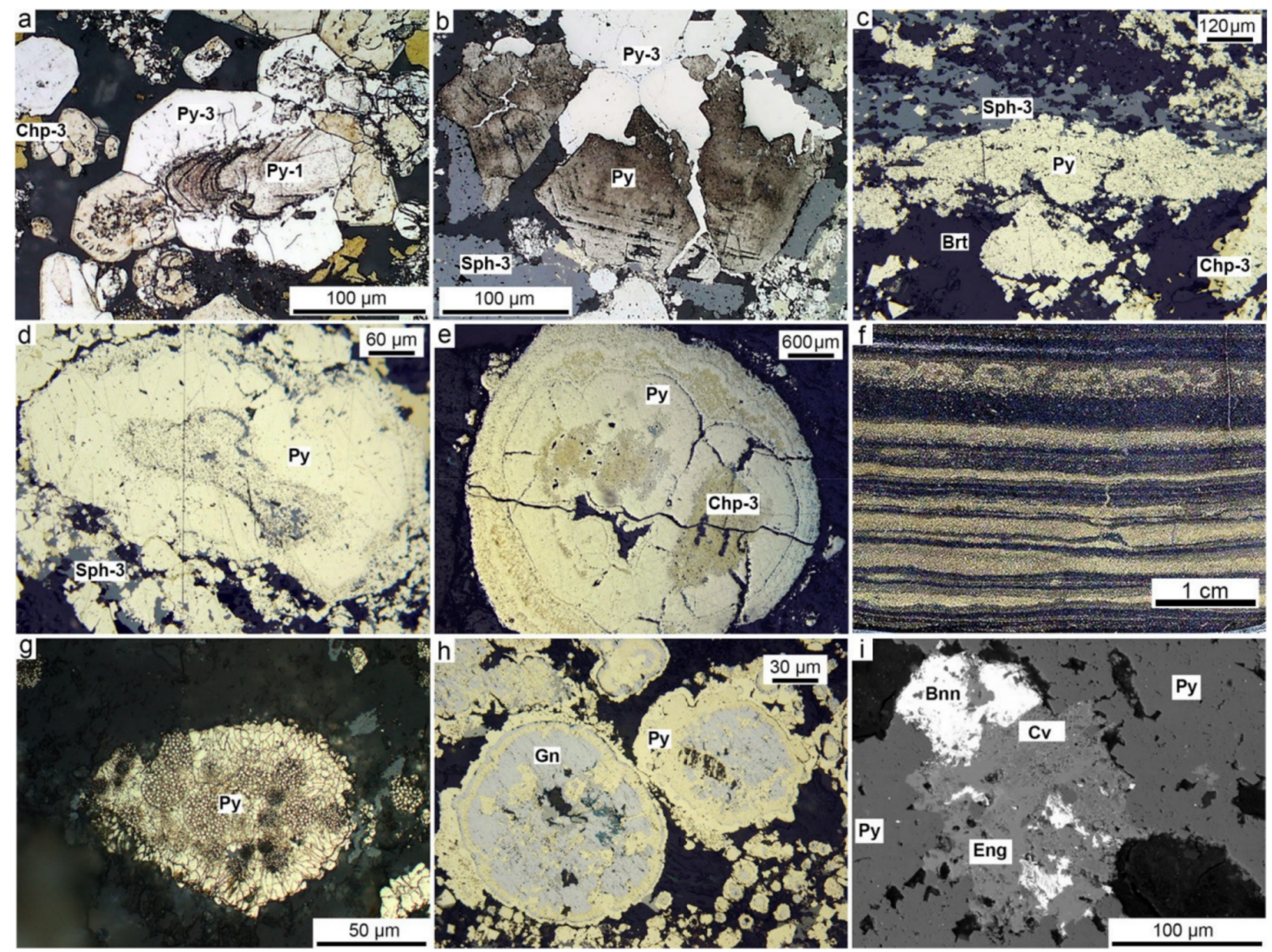

Figure 15. Mineralogical features of pyrite-rich diagenite of the Yaman-Kasy (a,b), Molodezhnoe $(\mathbf{c}, \mathbf{d})$, Aleksandrinskoe (e) and Saf'yanovskoe (f-i) deposits: (a) Relict pyrite-1 in euhedral crystal of pyrite-3; (b) pseudomorphic sooty pyrite (Py) replaced by anhedral pyrite-3; (c) layer of pyrite-rich diagenite in assemblage with barite and sphalerite; (d) zoned pyrite nodule; (e) pyrite nodule partly replaced by chalcopyrite; (f) intercalation of pyrite-rich diagenites and carbonaceous shales; (g) framboidal and crystalline pyrite nodule; (h) replacement of pyrite nodules by galena and tennantite; (i) enargite, bournonite and covellite in authigenic pyrite. (f) Polished sample, (a-e,g,h) reflected light, (i) SEM photo.

In the Molodezhnoe deposit, pyrite-rich diagenites are typically intercalated with barite-rich diagenites in the upper part of an apron of ore-clast material together with rare relict sphalerite-rich diagenites, see Figure 15c. The pyrite-rich diagenites are composed of fine- and coarse-grained pyrite and contain rare sphalerite inclusions. Fine-grained pyrite displays nodular microtextures and locally, the fine-grained cores are well-preserved in crystalline nodules, as shown in Figure 15d.

In the Aleksandrinskoe deposit, the layers of pyrite-rich diagenites are associated with barite ores. Pyrite nodules are subdivided into fine-grained and crystalline varieties. The fine-grained cores of the nodules are partly replaced by chalcopyrite and tennantite $\mathrm{Cu}_{9.25}\left(\mathrm{Fe}_{1.40} \mathrm{Zn}_{1.37}\right)_{2.77}$ $\left(\mathrm{As}_{3.38} \mathrm{Sb}_{0.3} \mathrm{Ag}_{0.13} \mathrm{Te}_{0.03}\right)_{3.84} \mathrm{~S}_{13.00}$, see Figure 15e.

In the Saf'yanovskoe deposit, the pyrite-rich diagenites are completely altered to thin layers mixed with organic matter presumably derived from adjacent carbonaceous shales, see Figure 15f. Framboidal, nodular and euhedral pyrite is abundant in diagenites formed after fine-clastic sulfide turbidite, while coarse clasts are well-preserved in sulfide breccias and turbidites. Framboidal pyrite nodules are surrounded by crystalline pyrite, see Figure $15 \mathrm{~g}$, and the cores of the nodules are partly replaced by galena and tennantite, see Figure $15 \mathrm{~h}$. Native gold, enargite, luzonite, famatinite, and diagenetic bournonite [77] inclusions are typical of authigenic pyrite, see Figure 15i. 


\subsection{Barite-Rich Diagenites}

Barite-rich diagenites are often associated with gossanites formed from seafloor oxidized sulfide bodies, which are characteristic of some VHMS deposits of the Urals (e.g., Molodezhnoe, Aleksandrinskoe), see Figure 16.
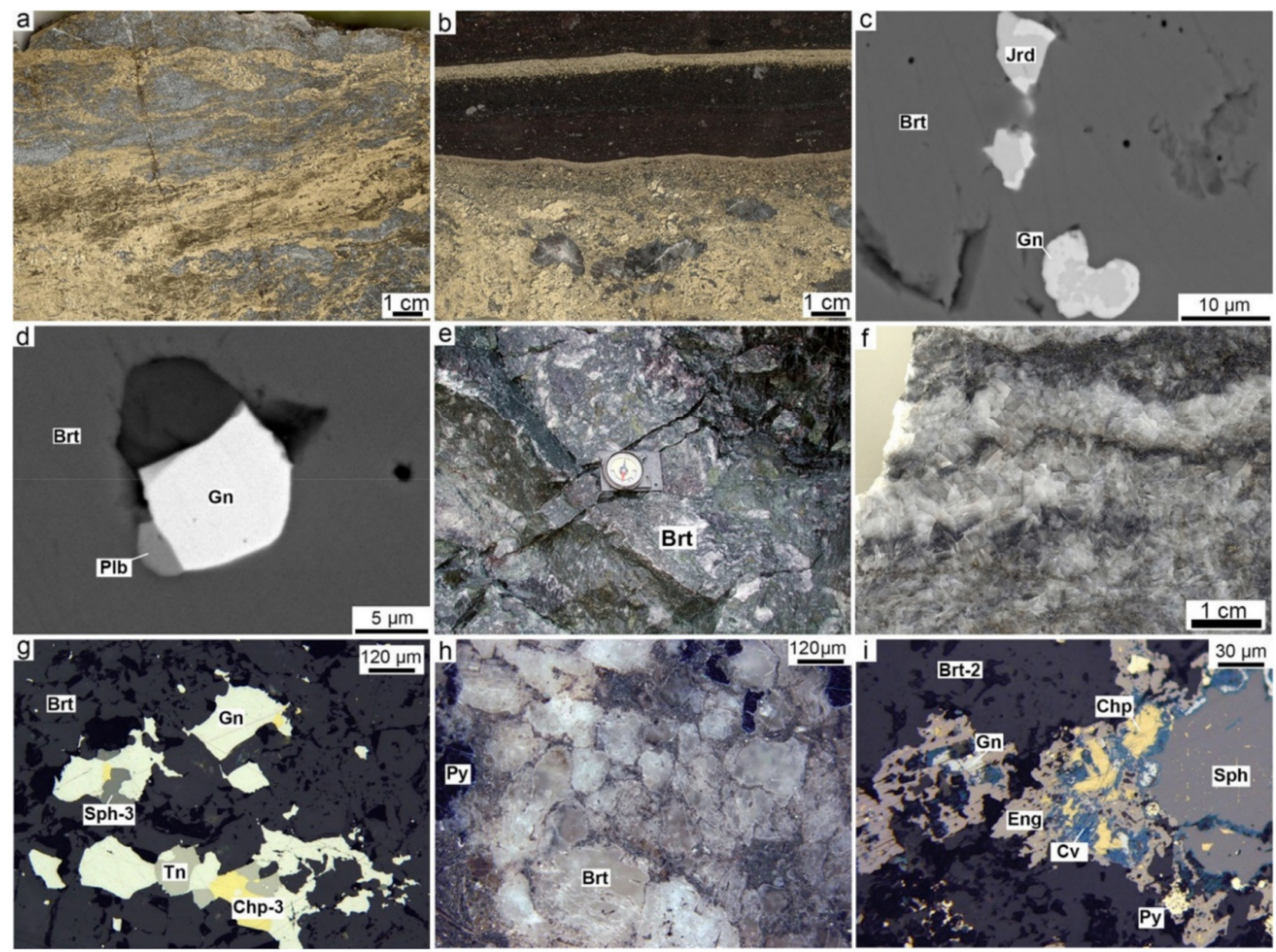

Figure 16. Mineralogical features of barite-rich diagenites of the Molodezhnoe (a-d), Aleksandrinskoe $(\mathbf{e}-\mathbf{g})$ and Saf'yanovskoe (h-i) deposits: (a) Intercalation of barite and pyrite layers; (b) fragments of barite in sulfide turbidite crowned by gossanites; (c) jordanite-galena intergrowth in barite; (d) polybasite-galena aggregate in barite; (e) layers of barite breccias between clastic pyrite and gossanites; (f) barite-rich diagenite; (g) galena-tennantite-chalcopyrite-sphalerite assemblage in barite; (h) clastic structure of barite-rich diagenite cemented by sulfides; (i) covellite-galena-enargite assemblage formed after chalcopyrite and sphalerite in barite-2. (a,b,f) Polished sample, (e) field photo, (g,i) reflected light, (c,d) SEM photo, (h) dark field reflected light.

In the Molodezhnoe deposit, barite-rich diagenites occur in the northern flank of the clastic ore lenses in association with sulfide turbidites and ferruginous gossanites [20]. In most cases, the barite-rich layers and lenses are intercalated with pyrite-rich diagenites, see Figure 16a. Some sulfide turbidites contain barite fragments indicating a seafloor origin of barite-rich diagenites, see Figure 16b. Relict rounded grains of chalcopyrite, galena and tennantite $\mathrm{Cu}_{9.91}\left(\mathrm{Zn}_{1.81} \mathrm{Fe}_{0.13}\right)_{1.94}\left(\mathrm{As}_{2.69} \mathrm{Sb}_{1.38} \mathrm{Ag}_{0.23}\right)_{4.3} \mathrm{~S}_{13.00}$ are enclosed in barite crystals, as well as abundant inclusions of sulfosalts, typically Sb-bearing (up to 3.8 wt.\% Sb) jordanite $\mathrm{Pb}_{13.51}\left(\mathrm{As}_{5.64} \mathrm{Sb}_{0.74}\right)_{6.38} \mathrm{~S}_{23.1}$ replaced by galena, see Figure 16c. Some barite crystals contain inclusions of As-rich polybasite $\left(\mathrm{Ag}_{11.98} \mathrm{Cu}_{3.42}\right)_{15.4}\left(\mathrm{Sb}_{1.24} \mathrm{As}_{0.69}\right)_{1.92} \mathrm{~S}_{11.6}$ and galena, see Figure $16 \mathrm{~d}$, as well as $\mathrm{Cu}$-bearing (up to $0.6 \mathrm{wt}$ \% $\mathrm{Cu}$ ) diaphorite $\mathrm{Ag}_{3.11} \mathrm{Cu}_{0.12} \mathrm{~Pb}_{1.73} \mathrm{Sb}_{3.07} \mathrm{~S}_{7.96}$ and $\mathrm{Ag-}, \mathrm{Hg}-$, Cd-bearing tetrahedrite-tennantite $\left(\mathrm{Cu}_{8.07} \mathrm{Ag}_{1.79}\right)_{9.88}\left(\mathrm{Zn}_{0.70} \mathrm{Fe}_{0.40} \mathrm{Hg}_{0.36} \mathrm{Cd}_{0.30}\right)_{1.85}\left(\mathrm{Sb}_{2.42} \mathrm{As}_{1.71}\right)_{4.13} \mathrm{~S}_{13.14}$.

In the Aleksandrinskoe deposit, the barite-rich diagenites occur at the flanks of the ore body and locally between clastic sulfide layers and ferruginous gossanites. Some multilayered ore bodies host hematite-rich barite breccias, see Figure 16e. The barite-rich diagenites are composed 
of subhedral barite crystals, see Figure $16 f$. Relict pyrite inclusions are replaced by chalcopyrite- 3 with galena and $\mathrm{Zn}$-rich tennantite $\left(\mathrm{Cu}_{10.10} \mathrm{Ag}_{0.23}\right)_{10.33}\left(\mathrm{Zn}_{1.78} \mathrm{Fe}_{0.17}\right)_{1.95}\left(\mathrm{As}_{2.75} \mathrm{Sb}_{1.23}\right)_{3.98} \mathrm{~S}_{13}$, see Figure $16 \mathrm{~g}$, and sphalerite. Acanthite and native gold have been previously found in barite-rich diagenites $[73,78]$.

The barite-rich diagenites at the southern flank of the Saf'yanovskoe deposit [79] are intercalated with pyrite-rich diagenites and contain relict and authigenic sulfides. Locally, the barite-1 layers display relict clastic aggregates cemented by fine-grained sulfides, see Figure 16h. Barite-2 is also a host for galena, Ag-bearing tennantite $\mathrm{Cu}_{10.00}\left(\mathrm{Zn}_{1.72} \mathrm{Cu}_{0.19} \mathrm{Fe}_{0.14}\right)_{2.05}\left(\mathrm{As}_{3.25} \mathrm{Sb}_{0.84}\right)_{4.09} \mathrm{~S}_{13.00}$ and Ag-bearing enargite $\left(\mathrm{Cu}_{2.98} \mathrm{Ag}_{0.01}\right)_{2.99}\left(\mathrm{As}_{0.98} \mathrm{Sb}_{0.01}\right)_{0.99} \mathrm{~S}_{4.00}$ formed after chalcopyrite in assemblage with galena and covellite. These minerals replace sphalerite-1 crystals, see Figure 16i. Very small inclusions of pyrargyrite are disseminated in barite.

\subsection{Hematite-Rich and Magnetite-Rich Diagenites (Halmyrolytes)}

The hematite-rich and magnetite-rich diagenites (halmyrolytes, gossanites or iron oxide facies), which are formed due to the seafloor oxidation of sulfide $\mathrm{Fe}^{2+}$, are a striking product of complete halmyrolysis of the Urals sulfide bodies. These rocks are considered the counterparts of the present-day ochre-rich gossans around the black smoker complexes and clastic sulfides [12]. Most gossanites include jasper, chlorite-hematite, chlorite-magnetite and carbonate-rich hematite or magnetite types intercalated with clastic sulfides, hyaloclastites and calcareous layers formed at the flanks of the deposits. Halmyrolysis is typically ended by the formation of stable hydroxide phases, which can be transformed to hematite and magnetite during later diagenesis [20].

The Dergamysh deposit lacks hematite-rich diagenites. Hematite only rims some serpentinite clasts in sulfide turbidites. Magnetite-rich layers were found in the hanging wall of the deposit, where magnetite replaces the serpentinite clasts.

In the Yubileynoe deposit, the quartz-hematite-calcite gossanites are intercalated with sulfide breccias exhibiting asymmetric load casts typical of gravitational mass flows, see Figure 17a. Sulfide breccias are partly replaced by chalcopyrite-2,3.
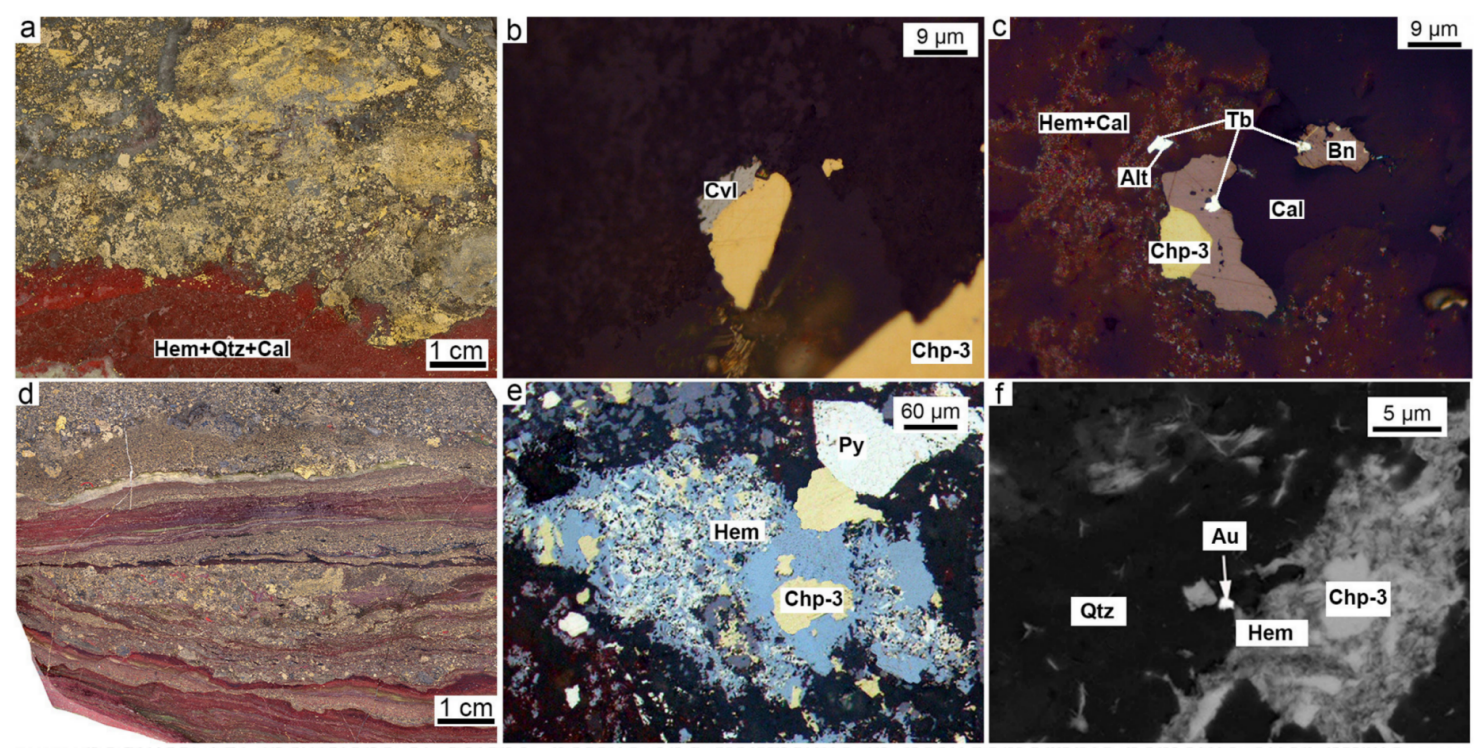

Figure 17. Mineralogical features of gossanites of the Yubileynoe (a-c) and Yaman-Kasy (d-f) deposits: (a) Red quartz-hematite-calcite gossanite and sulfide breccia layers; (b) inclusions of cervelleite and chalcopyrite- 3 in gossanite; (c) inclusions of chalcopyrite- and, bornite in assemblage with tellurobismuthite $(\mathrm{tb})$ and altaite intergrowths; (d) intercalation of gossanites with sulfide turbidites; (e) relict chalcopyrite-3 in hematite; (f) small grain of native gold in quartz near hematite with relict chalcopyrite-3. (a,d) Polished samples, (b,c,e) reflected light, (f) SEM photo. 
Inclusions of chalcopyrite- 3 contain $\mathrm{Cu}$ - and Se-bearing cervelleite $\left(\mathrm{Ag}_{3.30} \mathrm{Cu}_{0.48}\right)_{3.78} \mathrm{Fe}_{0.07}$ $\left(\mathrm{Te}_{0.93} \mathrm{Se}_{0.19}\right)_{1.12} \mathrm{~S}_{1.01}$ (up to 2.8 wt.\% Se), see Figure 17b, and Ag-rich native gold $\mathrm{Ag}_{0.64} \mathrm{Au}_{0.36}$. Chalcopyrite inclusions are associated with quartz, barite, bornite, altaite and Se-bearing tellurobismuthite, see Figure 17c. Rare small microinclusions of cobaltite, coloradoite, acanthite, Se-bearing hessite (up to 0.9 wt.\% Se) and altaite (up to $1.2 \mathrm{wt} \%$ Se), and tennantite $\mathrm{Cu}_{9.71}\left(\mathrm{Fe}_{0.27} \mathrm{Zn}_{1.57}\right)_{1.84} \mathrm{As}_{3.94} \mathrm{~S}_{13.00}$ can be found in gossanites. Numerous uraninite particles $(<3 \mu \mathrm{m})$ are associated with apatite, V-rich Mg-chlorite, micro-nodules of pyrite, Se-bearing galena and acanthite in a hematite-carbonate-quartz matrix of gossanites [16].

In the Yaman-Kasy deposit, the quartz-hematite gossanites layers are intercalated with clastic sulfides turbidites, see Figure $17 \mathrm{~d}$. The presence of pseudomorphic hematite after clasts of zoned pyrite- 2 and relics of pyrite- 2 in fine hematite aggregates are evidence of the seafloor oxidation origin of gossanites [20]. Hematite replaces sphalerite-3 and chalcopyrite-3, see Figure 17e. Small (up to $2 \mu \mathrm{m}$ ) grains of Ag-rich native gold $\left(\mathrm{Au}_{0.66} \mathrm{Ag}_{0.34}\right.$ to $\left.\mathrm{Au}_{0.72} \mathrm{Ag}_{0.28}\right)$ are disseminated in quartz nearby hematite and relict chalcopyrite aggregates, see Figure $17 \mathrm{f}$. Altaite occurs as very small $(<1 \mu \mathrm{m})$ inclusions in chalcopyrite-3, only.

The Molodezhnoe deposit yields the best layers of hematite-rich gossanites up to 0.5-m thick, recognized as a zone of full submarine oxidation to form a seafloor gossan [12,20]. Gossanites are intercalated with sulfide turbidites and chlorite shales, see Figure 18a, and exhibit numerous, well-preserved relict microtextures of primary clastic sulfides including pseudomorphic hematite after colloform pyrite clasts, see Figure 18b, zoned pyrite-2 and nodules of framboidal pyrite, see Figure 18c. Pseudomorphic hematite contains small $(<1 \mu \mathrm{m})$ inclusions of native gold and various tellurides (hessite, tellurobismuthite, coloradoite, volynskite, tsumoite, Ag-bearing (up to $0.7 \mathrm{wt} . \% \mathrm{Ag}$ ) tetradymite) in assemblage with authigenic chalcopyrite and Se-bearing (up to $2.6 \mathrm{wt}$.\% Se) galena, see Figure 18d,e.
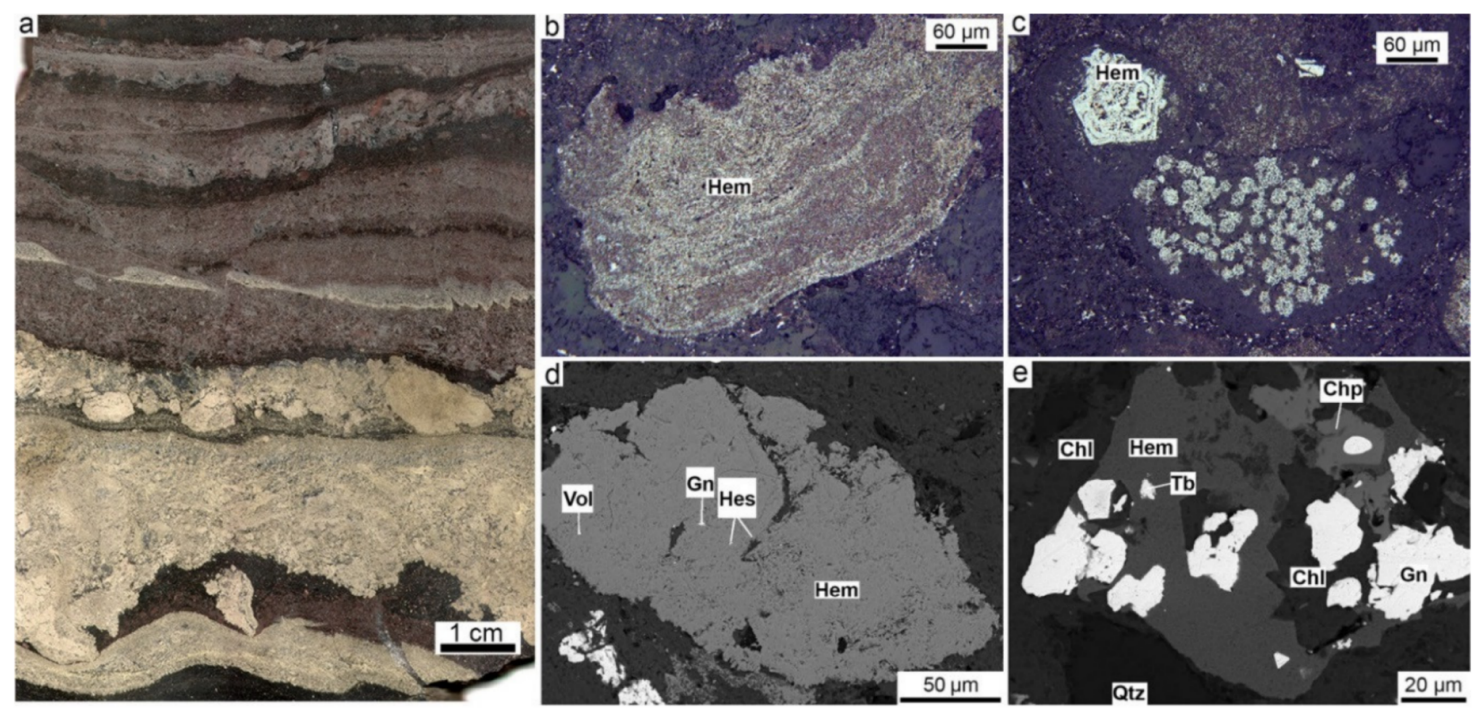

Figure 18. Mineralogical features of gossanites of the Molodezhnoe deposit: (a) hematite-chlorite gossanite layers intercalated with sulfide turbidites; (b) pseudomorphic hematite after colloform pyrite clast; (c) pseudomorphic hematite after zoned subhedral pyrite-2 and framboidal pyrite nodules; (d) inclusions of galena, hessite and volynskite in pseudomorphic hematite after pyrite clast; (e) intergrowth of chalcopyrite, galena and hematite with inclusions of tellurobismuthite in chlorite-quartz aggregate. (a) Polished samples, (b,c) reflected light, (d,e) SEM photo.

Typically, the Baymak-type deposits lack Fe-rich gossanites except for the Aleksandrinskoe deposit, where Fe-rich hematite-chlorite-carbonate gossanites are intercalated with barite, sulfides and calcareous hyaloclastic shales [20]. The gossanites often cover the barite layers, see Figure 19a, and consist of calcite, chlorite, hematite and quartz with rare apatite and monazite. An abundance 
pseudomorphic hematite after ore clasts, in particular, after colloform pyrite and framboidal pyrite nodules, occurs in the hematite-barite-rich matrix, see Figure 19b,c. The formation of pseudomorphic hematite is a result of the sequential seafloor mineral alteration allowing iron hydroxides to replace the sulfides and then to be gradually altered to hematite in the course of lithification [80]. Native gold is associated with chalcopyrite inclusions, see Figure 19d. Instead of native gold and relict sulfides, the gossanites contain microinclusions of tetradymite, tsumoite, rucklidgeite, hessite and altaite in pseudomorphic hematite after pyrite, chalcopyrite and sphalerite clasts. Tetradymite $\mathrm{Bi}_{2} \mathrm{Te}_{2} \mathrm{~S}$ occurs as isometric inclusions up to $10 \mu \mathrm{m}$ in size, see Figure $19 \mathrm{~g}$, and contains $0.53-0.66 \mathrm{wt} . \%$ Se and $0.3-1.07 \mathrm{wt} . \% \mathrm{Ag}$. Tsumoite (up to $7.79 \mathrm{wt} . \% \mathrm{~Pb}$ ), as well as altaite and hessite, forms intergrowths with tetradymite and inclusions of up to $5 \mu \mathrm{m}$ in pseudomorphic hematite in the chlorite-hematite matrix.
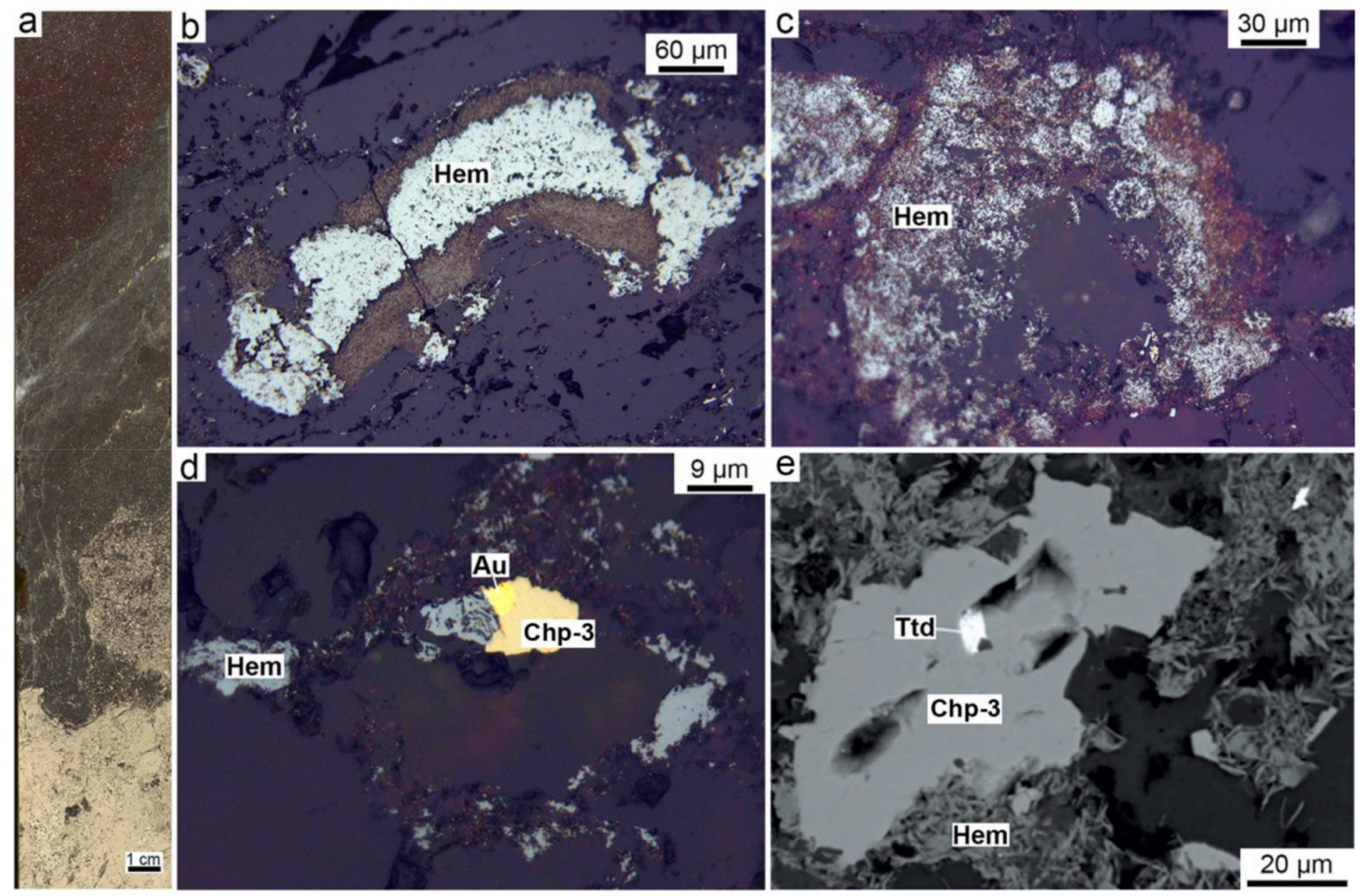

Figure 19. Mineralogical features of Fe-rich gossanites of the Aleksandrinskoe deposit: (a) Hematite gossanite on top of barite and clastic pyrite layers; $(\mathbf{b}, \mathbf{c})$ pseudomorphic hematite after colloform pyrite clast (b) and framboidal pyrite nodule (c); (d) native gold at the contact of chalcopyrite and hematite grains; (e) inclusion of tetradymite in chalcopyrite and hematite. (a) Polished sample, (b,c,d) reflected light, (e) SEM photo.

\section{Discussion}

\subsection{Arguments for Diagenetic Origin of Banded Sulfides and Barite}

The ore breccias and sandstones are often intercalated with thin banded sulfide layers at the flanks of clastic ore bodies. Banded sulfides could frequently be recognized as intercalated altered clastic sulfide layers on the basis of the load casts, which are typical of sulfide turbidites but are not characteristic of fallout settled sulfide particles [17,19,81], even in metamorphosed VHMS deposits [82]. The seafloor replacement origin is confirmed by the presence of synchronous clasts of fast-lithified barite and sulfide layers in slumping sulfide and barite breccias [18].

The alteration of clastic sulfide layers may be related either to the hydrothermal replacement or halmyrolysis and diagenesis. In the Kidd-Creek deposit, $\mathrm{Cu}$ enrichment is considered to be the main process of hydrothermal replacement of massive banded sulfides [83], and the origin of the Saf'yanovskoe deposit is considered to be similar, see Figure 4. The hydrothermal replacement of 
clastic sulfides is observed as cross-cutting zones in the cores of some sulfide mounds with the local formation of massive and veined textures. Hydrothermal mineral assemblages are largely controlled by fluid composition and physicochemical conditions and are not influenced by the primary composition or lithology of sulfide layers. In general, the pervasive hydrothermal replacement cannot be a simple explanation for the selective alteration of neighboring sulfide layers, which are altered in varying degrees and are commonly alternating with very well-preserved black shales, jaspers, calcareous claystones or hyaloclastic sandstones, likely formed far from the feeder zone. Sedimentary rocks intercalated with diagenetically altered sulfide turbidites are typically well-preserved. In contrast to the halmyrolysis and diagenesis of the layers, the hydrothermal alteration of sulfide turbidites would be expressed as a replacement by hydrothermal sulfides [84]. In ore diagenites, every layer exhibits a different degree of alteration that contrasts to the appearance of metamorphosed and/or hydrothermally altered sulfide turbidites [22]. Thus, the "diagenetic" hypothesis versus "hydrothermal replacement" is argued by the lack of hydrothermal alteration of adjacent background sediments.

Seafloor alteration and recrystallization of sulfide turbidites at the present-day black smoker vent sites provide important evidence for the diagenetic model. Replacement of pyrite clasts by authigenic chalcopyrite is typical for textures seen in modern clastic sulfides of the Atlantic Ocean $[19,21,22]$. In basaltic hyaloclastites, the pyrite clasts are replaced by authigenic chalcopyrite, while the chalcopyrite chimney clasts are replaced by bornite and euhedral pyrite aggregates. Euhedral pyrite crystals with porous cores are common for the lithified turbidites of the Menez Gwen hydrothermal field [24]. Pyrite nodules and authigentic chalcopyrite and bornite are identified in sulfide breccias of the Semenov-3 hydrothermal field [25]. Most clastic sulfides of the present-day and ancient VHMS deposits underwent a variable degree of alteration. Precipitation of pyrite around ore clasts in present-day ore clastic sediments indicates an on-going mineral formation after sedimentation [85]. For example, sphalerite, which is a product of würtzite inversion in chimneys clasts, was dissolved and reprecipitated at a lower temperature. In the Middle Valley area of the Juan-de-Fuca Ridge, the individual clasts are composed of an open network of pyrrhotite, sphalerite, and isocubanite partly filled and replaced by pyrite, barite and Fe oxides [86].

Diagenetic alteration is a preferred explanation for the correlation between the thickness of layers and their mineralogical features. The increase in the alteration intensity with a decreasing size of ore clasts (layer thickness) suggests that the bulk of these processes occurred in soft sulfide sediments. Granulometry is responsible for the perceived different degree of alteration because the fine-clastic sulfide turbidites are always more altered in comparison to sulfide breccias [22].

Seafloor conditions for the diagenetic alteration of sulfide turbidites are also supported by the stratified character both of $\mathrm{Cu}$ and $\mathrm{Zn}$ enrichment or leaching. The seafloor or early diagenetic nature of alteration is evident from the asymmetric mineral zoning of sulfide rhythms when the tops of the sulfide layers are enriched in authigenic chalcopyrite, bornite, sphalerite, and hematite [22,87,88]. The cyclic recurrence of asymmetric sulfide rhythms is explained by the variable oxidation state of the basin [87]. However, the hydrothermal-sedimentary hypothesis ignores the lateral zoning of sulfide layers and replacement of sulfides. Relict sulfides, barite and rocks are preserved in the foot of some thick layers of sulfide turbidites and sulfide breccias [19,22,89].

The low-temperature conditions for the formation of mineralization provide key genetic evidence for the seafloor alteration model. Stromeyerite, the formation of which is limited by an upper temperature of $67^{\circ} \mathrm{C}[90,91]$, was found in close assemblage with chalcocite, digenite, galena and covellite in bornite-rich diagenites. Similar high Se/S ratios of the hydrothermal minerals of chimney clasts and authigenic mineral counterparts could be evidence of the high temperature of formation of mineralization in both cases [81]. The higher Se content of sulfides is used as evidence of the high temperature of formation of hydrothermal ore or black smoker chimneys (Se is highly soluble in fluids at temperatures of $350^{\circ} \mathrm{C}$ ) [92-96]. In contrast, Se-poor chalcopyrite was found to precipitate at medium to low temperatures [97]. In pseudomorphic authigenic sulfides, however, the high Se contents reflect inclusions of selenides [98] or are inherited from primary ore chimney clasts with 
variable Se contents. Different Se contents of primary sulfides from different types of VHMS deposits also depend on the composition of host rocks [49]. Even a low Se content in solutions is sufficient for the precipitation of selenides and their stability area is expanded with decreasing temperature [99].

The replacement of pyrite by pyrrhotite is typically considered a metamorphic process [100,101]. In the Urals VHMS deposits, abundant pseudomorphic pyrrhotite is often considered the high-temperature mineral in the refining zone of VHMS deposits [102]. At the same time, its high-temperature hexagonal and low-temperature monoclinic types are combined in the feeder zones of the deposits. Pseudomophic pyrrhotite occurs in sulfide turbidites of metamorphosed (Mauk deposit [82]) and non-metamorphosed (Ishkinino, Dergamysh deposits [53]) deposits of the Urals, as well. All these turbidites contain serpentinite clasts. The thermodynamic modeling shows that the low-temperature formation of iron monosulfides requires only excesses of $\mathrm{Fe}^{2+}$ (e.g., the presence of olivine) in sulfide sediments [64]. In the Dergamysh deposits, the ore diagenites composed by nodular monocline pyrrhotite could be considered to be the low-temperature proxies, similarly to diagenetic pyrrhotite nodules of non-metamorphosed sedimentary iron deposits [103].

\subsection{Mineralogical Diversity of Ore Diagenites}

The mineralogical diversity of ore diagenites can be explained by different primary compositions of hydrothermal ore clasts and following processes of seafloor alteration. Every type of VHMS deposit is characterized by a specific mineralogical group of ore diagenites. In a range from ultramafic- and mafic- to bimodal mafic- and felsic-related VHMS deposits, the amount of sphalerite-, bornite-, galenaand barite-rich diagenites increases compared to pyrite- and chalcopyrite-rich types. This is consistent with general changes in the composition of hydrothermal ore facies and their clasts. The ultramafic- and mafic-related VHMS deposits are dominated by pyrite-chalcopyrite and colloform pyrite-marcasite crusts and pyrite-rich vent material with minor sphalerite. Barite-chalcopyrite and barite-sphalerite chimneys with minor crystalline pyrite are typical of bimodal felsic- and felsic-related VHMS deposits. The bimodal mafic-related VHMS deposits show all the mineral varieties of hydrothermal ore facies and their clasts [20].

In parallel to the types of VHMS deposits, ore diagenites exhibit distinctive mineral assemblages, see Table 2. In Atlantic-type deposits, the pyrrhotite- and chalcopyrite-rich diagenites contain abundant $\mathrm{Cu}, \mathrm{Co}$ and Ni sulfides and less abundant $\mathrm{Co}$ sulfoarsenides. Numerous tellurides and selenides occur in the chalcopyrite-rich diagenites of the Uralian-type deposits. The chalcopyrite-rich diagenites of the Baymak-type deposits host less diverse rare mineral assemblages. The minerals of the germanite group and $\mathrm{Cu}, \mathrm{Ag}$ and $\mathrm{Sn}$ sulfides are typical of the bornite-rich diagenites. Galena-sulfosalt assemblages are dominant in sphalerite-rich and barite-rich diagenites. The pyrite-rich diagenites are normally depleted in rare mineral assemblages. Surprisingly, hematite-rich diagenites often contain tellurides. The intermediate types of diagenites, e.g., bornite-bearing chalcopyrite- and sphalerite-rich diagenites, exhibit combinations of these mineralogical features. Authigenic native gold is observed in every type of diagenite. The largest gold grains (up to $1 \mathrm{~cm}$ in size) are typical of bornite-rich diagenites. The submarine supergene zones preserved in Urals VHMS deposits contain up to $80 \mathrm{ppm} \mathrm{Au} \mathrm{[12]} \mathrm{and}$ similar Au-enrichment is observed in oxidation zones of modern seafloor sulfides [104,105]. 
Table 2. Typical authigenic minerals of ore diagenites of the Urals VHMS deposits.

\begin{tabular}{|c|c|}
\hline $\begin{array}{l}\text { Mineral Types } \\
\text { of Diagenites }\end{array}$ & Authigenic Subordinate and Rare Mineral Assemblages \\
\hline Pyrrhotite-rich & $\begin{array}{l}\text { Chalcopyrite, "isocubanite", arsenopyrite, pentlandite, gersdorffite, } \\
\text { nickeline, cobaltite, native gold }\end{array}$ \\
\hline Chalcopyrite-rich & $\begin{array}{l}\text { Sphalerite, pyrite, Te- and Bi-tennantite, galena, phase between } \\
\text { cattierite and pyrite, cobaltpentlandite, mackinawite, pyrite, } \\
\text { pyrrhotite, cubanite, cobaltite, carrolite, cassiterite, coloradoite, } \\
\text { altaite, tellurobismuthite, tetradymite, hessite, petzite, stützite, } \\
\text { volynskite, calaverite, rucklidgeite, bornite, native antimony, } \\
\text { naumannite, clausthalite, kurilite, bohdanowiczite, roquesite, } \\
\text { magnetite, native gold, native tellurium, bornite, arsenopyrite }\end{array}$ \\
\hline Bornite-rich & $\begin{array}{l}\text { Sphalerite, pyrite, Te- and Bi-tennantite, goldfieldite, galena, } \\
\text { digenite, chalcocite, enargite, jalpaite, stromeyerite, germanite, } \\
\text { renierite, mackinstryite, stannite, stannoidite, mawsonite, colusite, } \\
\text { sulvanite, hessite, cervelleite, native gold }\end{array}$ \\
\hline Sphalerite-rich & $\begin{array}{l}\text { Chalcopyrite, pyrite, tennantite-tetrahedrite, barite, galena, } \\
\text { tetrahedrite, barite, enargite, covellite, argyrodite, native gold, } \\
\text { tennantite, enargite, bornite, galena, acanthite }\end{array}$ \\
\hline Pyrite-rich & $\begin{array}{l}\text { Tennantite, bornite, enargite, galena, tetrahedrite, bournonite, } \\
\text { famatinite, native gold, luzonite, petzite, hessite }\end{array}$ \\
\hline Barite-rich & $\begin{array}{l}\text { Tennantite, tetrahedrite, galena, acanthite, polybasite, diaphorite, } \\
\text { pyrargyrite, native gold, jordanite }\end{array}$ \\
\hline Hematite-rich & $\begin{array}{l}\text { magnetite, Se-rich galena, uraninite, acanthite, clausthalite, bornite, } \\
\text { digenite, coloradoite, hessite, cervelleite, altaite, tellurobismuthite, } \\
\text { volynskite, tetradymite, monheimite, native gold }\end{array}$ \\
\hline
\end{tabular}

Authigenic galena and selenide-bearing assemblages of seafloor altered ore diagenites are also typical of rare mineral assemblages in the superimposed terrestrial supergene weathering zones of Urals VHMS deposits $[98,115]$. Ore diagenites are dominated by a small group of Cu-rich minerals: Chalcocite, bornite, covellite, digenite and enargite. In the supergene blanket, these sulfides are intergrown with relict hydrothermal sulfides (pyrite, chalcopyrite, sphalerite). Similar secondary sulfide minerals are formed as a result of seafloor oxidation of seafloor hydrothermal sulfides [104].

\subsection{Microtextures and Mineral Evolution}

The general evolution of clastic sulfide sediments leading to the formation of ore diagenites is shown in Figure 20. Some microtextures (colloform, sooty pyrite, lattice "isocubanite", chalcopyrite emulsion in sphalerite-würtzite, coarse oscillatory zonation in pyrite and würtzite-sphalerite, acicular structure of chalcopyrite) are characteristic of primary ore clasts, only. These microtextures are destroyed in ore diagenites during early diagenesis giving way to abundant corrosion and replacement microtextures at the early diagenetic stage. Halmyrolysis results in the dissolution of primary sulfide clasts and the further formation of authigenic sulfides, barite and iron hydroxides. Primary rare mineral assemblages dissolve during halmyrolysis of fine-clastic sulfide turbidites. Early diagenetic sulfides are fine-grained and host well-preserved relicts of primary sulfides as do fine-grained nodules.

In contrast to destructive early diagenesis, late diagenesis has resulted in the dramatic formation of crystalline authigenic sulfides. Coarsely crystalline authigenic sulfides are devoid of relict primary sulfides. Pyrite is replaced by chalcopyrite or sphalerite and bornite, while pores have become filled with subhedral crystals of sulfides. During late diagenesis, fine-grained nodules are overgrown by subhedral crystals. Euhedral sulfide crystals and most of the rare authigenic minerals are formed at the same time. Interstitial veinlets occur in the fractures both between and within sulfide crystals, resulting from breakdown processes. Some veinlets with sulfides and rare authigenic minerals occur in sulfide nodules, as well as in the diagenite layers, and the veinlets are probably most typical of the 
end of late diagenesis to post-diagenetic processes. In weakly metamorphosed Urals VHMS deposits, different sulfide layers exhibit different degrees of alteration.

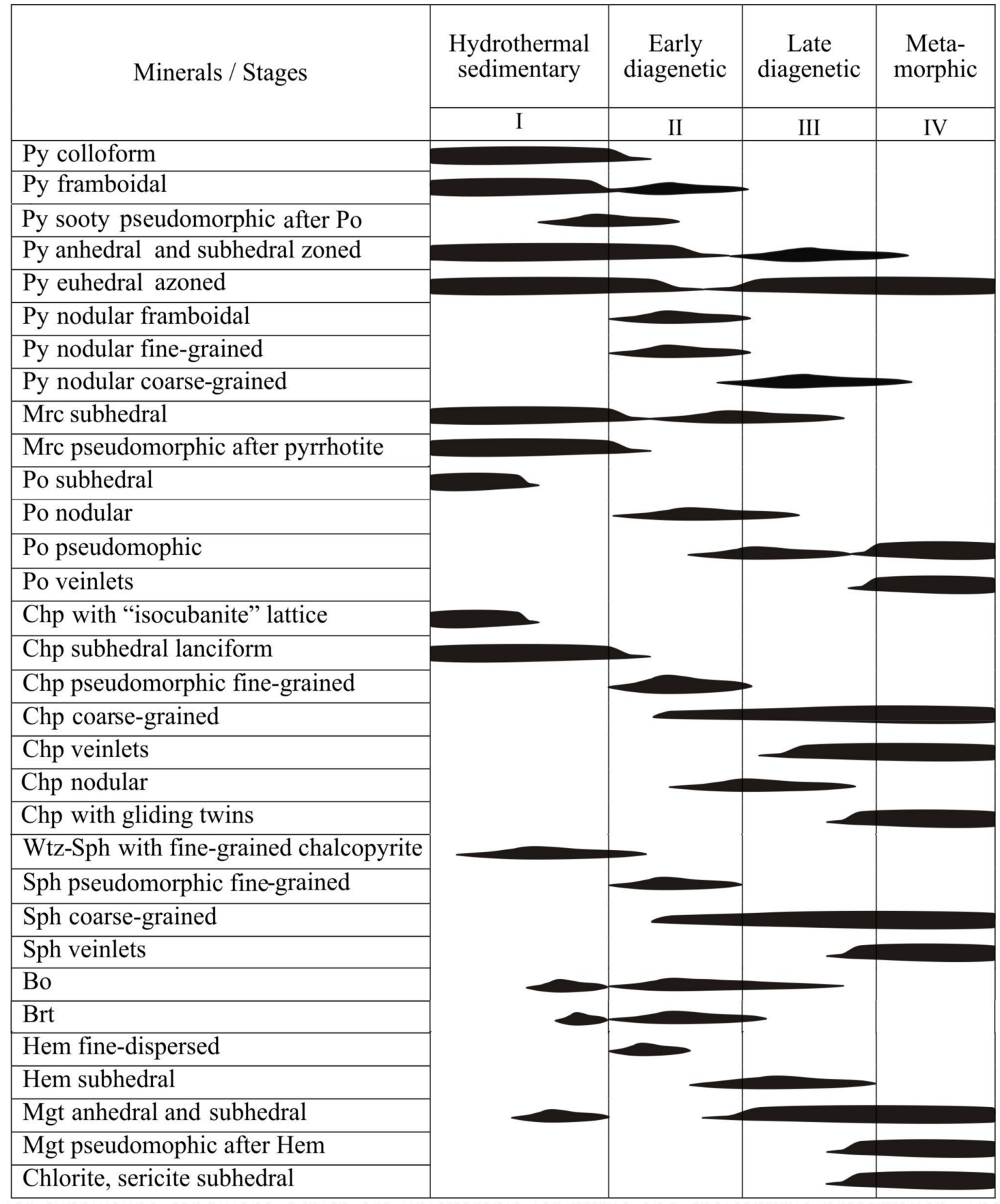

Figure 20. Simplified succession of major minerals of ore diagenites of the Urals VHMS deposits.

In spite of the common features and generalized mineral succession seen in ore diagenites, these are quite distinct in different ore sulfide turbidites, which include (1) Fe-rich and (2) Fe-poor types and (3) turbidites mixed with background ultramafic, hyaloclastic, carbonaceous and calcareous sediments.

The Fe-rich sulfide turbidites are subdivided into (1) pyrite (after pyrrhotite) type with minor sphalerite and (2) chalcopyrite-pyrite type with minor sphalerite. Type 1 has clasts of hydrothermal diffuser structures and hydrothermal crusts while type 2 has clasts of black smoker chimneys and are typical for ultramafic-, mafic-, and bimodal mafic-types of VHMS deposits. 
In type 1, pyrrhotite clasts become replaced by authigenic sooty and crystalline pyrite and marcasite. Sooty pyrite is crystallized prior to nodular and euhedral pyrite varieties. Minor sphalerite is absent, presumably, removed from Fe-rich layers with the formation of pyrite-rich diagenites. Oxidation of abundant colloform pyrite leads to low $\mathrm{pH}$ conditions of diagenesis [26]. Under acidic conditions, sphalerite dissolves faster than pyrite [26,116]. Hamyrolysis of sulfides is quite distinct from the hydrothermal processes in the absence of hydrothermal $\mathrm{H}_{2} \mathrm{~S}$, whereas leached $\mathrm{ZnS}$ could produce reduced $S\left(S^{0}, S^{2-}\right)$ necessary for the formation of authigenic pyrite [19]. This type of pyrite-rich diagenite is poor in tellurides, as well as evidence of primary diffuser clasts [67].

The evolution of type 2 of Fe-rich sulfide turbidites is more complex. Pyrrhotite- 1 clasts are replaced by sooty pseudomorphic pyrite and marcasite and then, by crystalline pyrite- 3 as well. The fine-clastic sphalerite- 1 and chalcopyrite-1, as well as pyrite-1, dissolve during early diagenesis. Colloform and dendritic pyrite are transformed to subhedral and then euhedral crystals and nodules. The dissolution of primary iron disulfides results in a dramatic decrease in the $\mathrm{pH}$ [87]. The dissolution rates of sulfides and sulfates were probably very different. The present-day ocean exhibits the following range of dissolution rate of the $2-\mu \mathrm{m}$ particles (days): Anhydrite $(0.5) \rightarrow$ pyrrhotite $(11) \rightarrow$ marcasite (23) $\rightarrow$ sphalerite (48) $\rightarrow$ barite (58) $\rightarrow$ pyrite (106-218) $\rightarrow$ chalcopyrite (964) [117]. Halmyrolysis of sulfides triggered the replacement of primary pyrite clasts by fine-grained chalcopyrite- 2 and, more rarely, by sphalerite-2. At low $\mathrm{pH}$, chalcopyrite- 2 is likely to be more stable than sphalerite-2. Chalcopyrite-2 pseudomorphs pyrite clasts typical of the earlier stage of diagenesis [22].

In most cases, sphalerite- 2 is recrystallized to twinned sphalerite- 3 or is replaced by chalcopyrite- 3 . During late diagenesis, coarse-grained chalcopyrite- 3 forms associated with sphalerite- 3 , galena and tennantite coupled with authigenic tellurides, selenides, sulfides, galena, sulfosalts and native gold. This assemblage forms veinlets and inclusions in fractured pyrite crystals and pyrite and chalcopyrite nodules [67] leading to the formation of chalcopyrite-rich diagenites. Rare sphalerite-rich diagenites occur in thin layers intercalated with thick layers of chalcopyrite- and pyrite-rich diagenites. It is suggested that the decreasing $\mathrm{pH}$, likely to occur during the late diagenesis of these layers, was buffered by abundant higher $\mathrm{pH}$ seawater and/or mixing with background pelitic sedimentary material [19]. Pseudomorphic magnetite and hematite are late diagenetic minerals replaced by pseudomorphic iron hydroxides. The chalcopyrite-rich diagenites are recrystallized to chalcopyrite- 4 with a glide twin structure. This chalcopyrite- 4 is associated with metagenetic quartz and chlorite and occurs in cleavage fractures and is usually not accompanied by rare authigenic minerals [67].

Accessory minerals evolve in parallel with major sulfides, see Figure 21. Any Co and Fe sulfarsenides and $\mathrm{Fe}, \mathrm{Co}, \mathrm{Bi}, \mathrm{Au}, \mathrm{Ag}, \mathrm{Hg}$ and $\mathrm{Pb}$ tellurides occurring in chimney clasts are replaced by appropriate sulfosalts, galena, $\mathrm{Co}, \mathrm{Cu}$ and $\mathrm{Ag}$ sulfides, native tellurium and native gold during the earlier stage of sulfide oxidation. This process is complemented by the formation of secondary tellurides and sulfarsenides during later diagenesis under favorable reducing conditions. Subordinate tellurides and sulfotellurides were found in strongly altered sulfide layers and sulfide nodules. Thus, primary tellurides and arsenides dissolve during halmyrolysis of ore clasts. However, most authigenic counterparts are formed during late diagenesis. Authigenic tellurides and arsenides occur in sulfide veinlets or at the front of diagenetic replacement, while primary hydrothermal varieties are precipitated synchronously with hydrothermal sulfide crystals [66]. Rare mineral assemblages are more diverse in ore diagenites in comparison with material from chimneys and other hydrothermal seafloor mineralization. In addition to tellurides and arsenides, mature chalcopyrite-rich diagenites contain abundant selenides, the Te and Se derived from black and grey smoker chimney clasts [49]. 


\begin{tabular}{|c|c|c|c|c|}
\hline \multirow[t]{2}{*}{ Stage/minerals } & $\begin{array}{l}\text { Hydrothermal } \\
\text { sedimentary }\end{array}$ & $\begin{array}{c}\text { Early } \\
\text { diagenetic }\end{array}$ & $\begin{array}{c}\text { Late } \\
\text { diagenetic }\end{array}$ & $\begin{array}{c}\text { Meta- } \\
\text { morphic }\end{array}$ \\
\hline & I & II & III & IV \\
\hline \multicolumn{5}{|l|}{ Tennantite and tetrahedrite } \\
\hline \multicolumn{5}{|l|}{ Galena } \\
\hline \multirow{2}{*}{\multicolumn{5}{|c|}{ Cassiterite }} \\
\hline $\mathrm{Cu}-\mathrm{Co}-\mathrm{Ni}$ sulfides & & & & \\
\hline \multicolumn{5}{|l|}{ Fe-, Co-arsenides and sulfoarsenides } \\
\hline \multicolumn{5}{|l|}{$\mathrm{Bi}-, \mathrm{Hg}-, \mathrm{Pb}-, \mathrm{Fe}-$ tellurides } \\
\hline \multicolumn{5}{|l|}{ Ag-, $\mathrm{Pb}$ - selenides } \\
\hline \multicolumn{5}{|l|}{ Enargite group } \\
\hline \multicolumn{5}{|l|}{ Germanite group } \\
\hline \multicolumn{5}{|l|}{$\mathrm{Cu}-\mathrm{Ag}-\mathrm{Pb}$ sulphosalts } \\
\hline \multicolumn{5}{|l|}{ Ag-,Cu-, In-, Sn-sulfides } \\
\hline Native gold and electrum & & & & \\
\hline
\end{tabular}

Figure 21. Succession of formation of subordinate and minor minerals of ore diagenites of the Urals VHMS deposits.

In weakly metamorphosed VHMS deposits, tellurides are the products of primary syngenetic hydrothermal growth of chimneys (Stage 1) and by the replacement of primary hydrothermal sulfide clasts by diagenetic chalcopyrite or iron hydroxides in ore diagenites (Stage 2). Tellurides are also found in many metamorphosed deposits of the Urals and it is suggested that tellurides may also be formed during hydrothermal overprinting or later metamorphic hydrothermal events $[82,108,118,119]$. The important role of metamorphic-hydrothermal processes is proved for tellurides of Carlin-type and orogenic gold deposits [100], and this process can be proposed for later metamorphic hydrothermal veins of VHMS deposits. However, in VHMS deposits, the main feature of metamorphism versus diagenesis is the formation of aluminosilicate minerals [9]. In ore diagenites of weakly metamorphosed Molodezhnoe, see Figure 9i, and Yaman-Kasy, see Figure 8e, deposits, authigenic chalcopyrite and tellurides are partly replaced by chlorite. It is suggested that tellurides, as well as sulfides, could be replaced by aluminosilicates during early metamorphism of ore diagenites. In strongly metamorphosed deposits, diagenetic tellurides may be redeposited in epigenetic veins during collision processes or the regressive stage of metamorphism (Stage 3). These tellurides-3 are absent in the non-metamorphosed deposits studied herein. In contrast to tellurides-3, no metamorphic selenides could be found because $\mathrm{Se}^{2-}$ then substitutes for $\mathrm{S}^{2-}$ in high-temperature metamorphic chalcopyrite [92].

The Fe-poor sulfide turbidites occur in some Uralian and mostly in Baymak types of the deposits. The mineral succession of these turbidites is distinct from that of Fe-rich varieties. The Fe-poor breccias and turbidites host abundant clasts of barite and sphalerite of white smokers and clear diffusers. Breccias with abundant chalcopyrite gray smoker clasts can locally be found. Colloform pyrite, marcasite and pyrrhotite are rarely found in these deposits [49]. The variable conditions of seafloor alteration depend on the primary proportions between pyrite, chalcopyrite and sphalerite, which is responsible for controlling $\mathrm{pH}$. Dissolution of sphalerite could be favorable for subalkaline conditions, which are unfavorable for pyrite and chalcopyrite preservation. The presence of dominant primary sphalerite consequently results in leaching of pyrite and enrichment in sphalerite, supported by physicochemical modeling [120]. The presence of ubiquitous sphalerite in seafloor gossans suggests that sphalerite or at least its Fe-poor variety may be locally resistant to oxidation under more alkaline conditions [26].

During early diagenesis, the dissolved fine-clastic sulfides could be sources for reduced $\mathrm{S}$ leading to the formation of authigenic sulfides during late diagenesis. In this succession, pyrite and chalcopyrite are replaced by tennantite, bornite and sphalerite-2,3. The sphalerite-rich diagenites can be intercalated with chalcopyrite-rich varieties. The chalcopyrite-rich diagenites are the products of the seafloor 
alteration of ore turbidites composed of fragments of chalcopyrite-rich grey smokers rather than simple replacement of pyrite clasts. The nodular pyrite-rich diagenites are associated with barite-rich varieties and this is related to the alteration of clastic sulfides containing abundant pyrite-barite white smoker clasts. The pyrite-rich diagenites contain nodules and euhedral pyrite crystals as a result of diagenesis of thick layers with the restricted influence of more alkaline seawater.

The bornite-, sphalerite- and barite-rich diagenites are abundant in these types of VHMS deposits. The $\mathrm{Cu}$ and $\mathrm{Ag}$ sulfides of the chalcocite and acanthite groups and the minerals of the germanite and enargite groups are abundant at the replacement front of chalcopyrite and sphalerite by bornite. They are derived from dissolved clasts of hydrothermal sulfides. Tellurides are rare except for hessite and cervelleite; the Te- and Bi-bearing tennantite, Ag-bearing tetrahedrite and $\mathrm{Cu}-\mathrm{Pb}$ sulfosalts are associated with galena and barite. In mature diagenites, the higher amount of $\mathrm{SO}_{4}{ }^{2-}-, \mathrm{As}^{3+}-, \mathrm{As}^{5+}$, $\mathrm{Ge}^{4+}-, \mathrm{Te}^{4+}-, \mathrm{Sb}^{3+}-, \mathrm{Sb}^{5+}$ - and $\mathrm{V}^{5+}$-bearing minerals is a testament to the increasing fluid oxidation state due to the influence of oxygenated seawater. Vanadium itself is considered a main indicator of seawater influence on oxidized sulfides [94]. Hematite and magnetite are the final proxies to these conditions. Native gold grains are larger in comparison to hydrothermal native gold grains (up to $1 \mathrm{~cm}$ in bornite-rich diagenites). In general succession, the sizes and grades of galena, barite, native gold and sulfosalts aggregates increased in this succession. Seawater is unfavorable for the dissolution of galena and migration of $\mathrm{Pb}$ [26], thus galena is always formed in ore diagenites and galena-rich diagenites are typically intercalated with sphalerite-rich varieties.

Some VHMS deposits (Aleksandrinskoe, Saf'yanovskoe) host huge amounts of barite-rich diagenites. The hematite-barite diagenites are formed as a result of the oxidation of massive sulfide ores during their interaction with seawater. Barite easily dissolves in seawater [117]; however, it can be contemporaneously precipitated due to an excess of $\mathrm{SO}_{4}{ }^{2-}$ in seawater. This excess may be provided by seafloor oxidation of sulfides. Coeval dissolution and precipitation of barite in seawater resulted in its recrystallization and formation of banded barite diagenites after barite-sulfide sandstones. It is suggested that these diagenites are formed due to seafloor oxidation of sulfide sulfur with the exchange of $\mathrm{SO}_{4}{ }^{2-}$ with seawater. The $\mathrm{S}$ isotopic composition of barite is slightly enriched in $\mathrm{S}^{32}$ isotope in comparison with Silurian and Devonian seawater [17].

The trends of mineral evolution also depend on the composition of background sedimentary material mixed with sulfide turbidites, which changes acid-base and redox conditions of pore fluids. The presence of ultramafic clasts (Fe-rich olivine or pyroxene) increases the stability of pyrrhotite clasts and the formation of low-temperature iron monosulfides (pyrrhotite) [17,64]. Clastic sulfides mixed with hyaloclastic material during diagenesis become enriched in authigenic sphalerite or chalcopyrite with nodular varieties $[18,67]$. Organic matter is important for the formation of authigenic framboidal, nodular and euhedral pyrite in black shale-associated VHMS deposits of the Rudny Altay type [23,89]. Calcareous material along with hyaloclastic and sulfide clasts is responsible for the fixation of $\mathrm{Fe}^{3+}$ hydroxides during gossan formation on the seafloor [20]. Silicates and carbonates consuming hydrogen ions provide acid buffering reactions favorable for $\mathrm{Fe}^{3+}$ hydroxide precipitation [26].

\section{Conclusions}

In weakly metamorphosed massive sulfide deposits of the Urals, banded sulfides are recognized as products of seafloor alteration of fine-clastic sulfide sediments to form ore diagenites. The ore diagenites include pyrrhotite-, chalcopyrite-, bornite-, sphalerite-, barite- and hematite-rich types. The amount of sphalerite-, bornite- and barite-rich diagenites increases in a progressive range from ultramafic- to bimodal mafic- and bimodal felsic-related deposits.

1. Each type of ore diagenites exhibits specific rare mineral assemblages and microtextures. Mineral diversity of the ore diagenites is explained by different primary compositions of ore clasts and the maturity of diagenesis. Tellurides, sulfarsenides, fahlores, galena, and native gold show a dual nature since they are formed both in primary smoker chimneys and in ore diagenites. Selenides, 
$\mathrm{Cu}-\mathrm{Ag}$ and $\mathrm{Cu}-\mathrm{Sn}$ sulfides and the minerals of the germanite group are observed only in mature bornite-rich diagenites.

2. Mineral evolution of clastic sulfide sediments is coeval with their textural evolution. The ore diagenites exhibit no hydrothermal features in contrast to dominant replacement and nodular microtextures. Several trends of diagenetic replacements are constrained in ore diagenites. The style and intensity of alteration depend on variable primary composition, sizes and proportions between hydrothermal ore clasts and serpentinite, hyaloclastite, carbonaceous and calcareous material in terms of influencing the $\mathrm{pH}$ and oxidation conditions during mineral evolution. In ultramafic-hosted deposits, the chalcopyrite- and pyrrhotite-rich diagenites contain $\mathrm{Cu}$-Co-Ni sulfides. Tellurides and selenides are typical of some chalcopyrite-rich diagenites in the Uralian type of the deposits. The minerals of the germanite group, $\mathrm{Cu}-\mathrm{Ag}$ and $\mathrm{Cu}-\mathrm{Sn}$ sulfides are characteristic of mature bornite-rich diagenites. The barite- and sphalerite-rich diagenites host abundant galena and sulfosalts. Diverse tellurides are disseminated in hematite-rich diagenites, the extreme products of halmyrolysis. All ore diagenites are enriched in native gold.

3. In general, the ore diagenites are characterized by higher proportions of $\mathrm{SO}_{4}{ }^{2--}-\mathrm{As}^{3+}-, \mathrm{As}^{5+}-$, $\mathrm{Sb}^{3+}-, \mathrm{Sb}^{5+}-, \mathrm{V}^{5+}-, \mathrm{Fe}^{3+}$ - and $\mathrm{Ge}^{4+}$-bearing minerals versus reduced forms. These reflect the influence of oxygenated seawater on the seafloor supergene alteration of sulfide turbidites. Halmyrolysis triggered enrichment in economically important $\mathrm{Cu}, \mathrm{Co}, \mathrm{Se}, \mathrm{Ge}, \mathrm{Zn}, \mathrm{Bi}, \mathrm{Pb}, \mathrm{Au}$ and $\mathrm{Ag}$ in some of the ore diagenites.

Supplementary Materials: The following are available online at http:/ / www.mdpi.com/2075-163X/9/3/150/s1, Table S1: Chemical composition of authigenic minerals of ore diagenites of the Urals VHMS deposits (wt \%).

Author Contributions: V.V.M., sampling and study of massive sulfides of the deposits, reconstructions of sulfide mounds, interpretation of mineral successions, writing of paper; N.R.A., study of massive sulfides of the Aleksandrinskoe, Yubileynoe and Molodezhnoe deposits, interpretation of the results, writing of paper; N.P.S., study of massive sulfides of theee Saf'yanovskoe and Yaman-Kasy deposits, interpretation of the results, writing of paper; A.S.T., study of massive sulfides of the Yubileynoe deposit, writing of paper; I.Y.M., study of massive sulfides of the Dergamysh deposit, writing of paper; R.R.L., study of pyrite succession, language improvement; R.J.H., sampling of sulfides, discussions, language improvement; V.A.K., microprobe analyses; I.A.B., electron microscopic studies; S.P.M., study of mineralogy of chimney fragments of the Yaman-Kasy deposits, reconstruction of sulfide mound, interpretation of the results; S.G.R., study of geology, reconstruction of sulfide mound of massive sulfides of Aleksandrinskoe deposit.

Funding: This research was supported by State Contract of the Institute of Mineralogy UB RAS (project for 2019-2021).

Acknowledgments: The authors are grateful to V.V. Zaykov, B. Buchman, J-J. Orgeval, C. Stanley, K. Becker, J. Spratt, T. Wighton, T. Greenwood and D. Steele for help in research. The authors are grateful to two anonymous reviewers and an Academic Editor for their detailed comments, which helped us to greatly improve our manuscript.

Conflicts of Interest: The authors declare no conflict of interest.

\section{References}

1. Peter, J.M.; Scott, S.D. Windy Craggy, Northwestern British Columbia: The world's largest Besshi-type deposits. Rev. Econ. Geol. 1999, 8, 261-295. [CrossRef]

2. Solomon, M.; Tornos, F.; Large, R.R.; Badham, J.N.P.; Both, R.A.; Kin, Z. Zn-Pb-Cu volcanic-hosted massive sulfide deposits criteria for distinguishing brine pool-type from black smoker-type sulfide deposition. Ore Geol. Rev. 2004, 25, 259-283. [CrossRef]

3. Tornos, F.; Peter, J.M.; Allen, R.; Conde, C. Controls on the siting and style of volcanogenic massive sulphide deposits. Ore Geol. Rev. 2015, 68, 142-163. [CrossRef]

4. Genna, D.; Gaboury, D. Deciphering the hydrothermal evolution of a VMS system by LA-ICP-MS using trace elements in pyrite: An example from the Bracemac-McLeod deposits, Abitibi, Canada, and implication for exploration. Econ. Geol. 2015, 110, 2087-2108. [CrossRef]

5. Kajiwara, Y.; Hyrayama, H. Diagenetic chemical differentiation of Kuroko ore deposits. Min. Geol. 1983, 33, 149-164. (In Japanese) 
6. Peter, J.M.; Kjarsgaard, M.I.; Goodfellow, W.D. Hydrothermal sedimentary rocks of the Heath Steel Belt, Bathurst Mining Camp. New Brunswick: Part 1. Mineralogy and mineral chemistry. In Massive Sulfide Deposits of the Bathurst Mining Camp, New Brunswick, and Nothern Maine; Goodfellow, W.D., McCutcheon, S.R., Peter, J.M., Eds.; Economic Geology Monograph; Society of Economic Geologist: Littleton, CO, USA, 2003; Volume 11, pp. 361-390. [CrossRef]

7. Solomon, M.; Walshe, D. Formation of massive sulfide deposits on sea floor. Econ. Geol. 1979, 69, 947-973. [CrossRef]

8. Zlotnik-Khotkevich, A.G. Diagenetic transformations of massive sulfide ores. Geol. Rudn. Mestorozh. 1992, 34, 83-98. (In Russian)

9. Yarosh, P.Y. Diagenesis and Metamorphism of Massive Sulfide Ores in the Urals; Nauka: Moscow, Russia, 1973; 240p. (In Russian)

10. Constantinou, G.; Govett, J.S. Geology, geochemistry and genesis of Cyprus sulfide deposits. Econ. Geol. 1973, 68, 843-858. [CrossRef]

11. Large, R. Australian volcanic-hosted massive sulfide deposits: Features, styles, and genetic models. Econ. Geol. 1992, 87, 113-128. [CrossRef]

12. Maslennikov, V.V.; Zaykov, V.V. Erosion and oxidation of sulfide mounds on the bottom of the Uralian Paleoocean. Dokl. Acad. Nauk USSR 1991, 319, 1434-1437. (In Russian)

13. Gablina, I.F.; Gorkova, N.V.; Semkova, T.A.; Stepanova, T.V. Diagenetic alteration of copper sulfides in modern ore-bearing sediments of the Logachev-1 hydrothermal field (Mid-Atlantic ridge $1445 \mathrm{~N}$ ). Lithol. Miner. Resour. 2006, 41, 27-44. [CrossRef]

14. Hannington, M.D.; Thompson, G.; Rona, P.A.; Scott, S.D. Gold and native copper in supergene sulphides from the Mid-Atlantic Ridge. Nature 1988, 333, 64-66. [CrossRef]

15. Herzig, P.M.; Hannington, M.D.; Scott, S.D.; Maliotis, G.; Rona, P.A.; Tompson, G. Gold-rich sea-floor gossans in the Troodos ophiolite and on the Atlantic Ridge. Econ. Geol. 1991, 86, 1747-1755. [CrossRef]

16. Ayupova, N.R.; Melekestseva, I.Y.; Maslennikov, V.V.; Tseluyko, A.S.; Blinov, I.A.; Beltenev, V.E. Uranium accumulation in modern and ancient Fe-oxide sediments: Examples from the Ashadze-2 hydrothermal sulfide field (Mid-Atlantic ridge) and Yubileynoe massive sulfide deposit (South Urals, Russia). Sediment. Geol. 2018, 367, 164-174. [CrossRef]

17. Herrington, R.J.; Zaykov, V.V.; Maslennikov, V.V.; Brown, D.; Puchkov, V. Mineral deposits of the Urals and links to geodynamic evolution. In Economic Geology One Hundredth Anniversary Volume; Hedenquist, J.W., Thompson, J.F.H., Goldfarb, R.J., Richards, J.P., Eds.; Society of Economic Geologist: Littleton, CO, USA, 2005; pp. 1069-1095. [CrossRef]

18. Maslennikov, V.V. Sedimentogenesis, Halmyrolysis and Ecology of Massive Sulfide Paleohydrothermal Fields; Geotur: Miass, Russia, 1999; 348p. (In Russian)

19. Maslennikov, V.V. Lithogenesis and Formation of Massive Sulfide Deposits; IMin UB RAS: Miass, Russia, 2006; 384p. (In Russian)

20. Maslennikov, V.V.; Ayupova, N.R.; Herrington, R.J.; Danyushevskiy, L.V.; Large, R.R. Ferruginous and manganiferous haloes around massive sulphide deposits of the Urals. Ore Geol. Rev. 2012, 47, 5-41. [CrossRef]

21. Rusakov, V.Y.; Ryzhenko, B.N.; Roshchina, I.A.; Kononkova, N.N.; Karpukhina, V.S. Devonian ore clastic turbidites of the Molodezhnoe massive copper deposit, Southern Urals. Geochem. Int. 2015, 53, 624-650. [CrossRef]

22. Safina, N.P.; Maslennikov, V.V. Litologo-mineralogical zonality of sulfide cyclites of the Yaman-Kasy and Safyanovskoye massive sulfide deposits. Dokl. Earth Sci. 2008, 419, 804-806. [CrossRef]

23. Safina, N.P.; Maslennikov, V.V. Clastic Ores from the Yaman-Kasy and Saf'yanovskoe Massive Sulfide Deposits (Urals); Ural Branch of RAS: Miass, Russia, 2009; 260p. (In Russian)

24. Lein, A.Y.; Bogdanov, Y.A.; Maslennikov, V.V.; Li, S.; Ulyanova, N.V.; Maslennikova, S.P.; Ulyanov, A.A. Sulfide Minerals in the Menez Gwen Nonmetallic Hydrothermal Field (Mid_Atlantic Ridge). Lithol. Miner. Resour. 2010, 45, 305-323. [CrossRef]

25. Melekestseva, I.Y.; Maslennikov, V.V.; Safina, N.P.; Nimis, P.; Maslennikova, S.P.; Beltenev, V.; Rozhdestvenskaya, I.; Danyushevsky, L.; Large, R.; Artemyev, D.A.; et al. Sulfide breccias from the Semenov-3 hydrothermal field, Mid-Atlantic Ridge: Authigenic mineral formation and trace element pattern. Minerals 2018, 8, 321. [CrossRef] 
26. Ridley, W.I. Weathering Processes. In Volcanogenic Massive Sulfide Occurrence Model; Pat Shanks, W.C., Thurston, R., Eds.; Scientific Investigation Report 2010-50-70-C; U.S. Geological Survey: Reston, VA, USA, 2012; Chapter 13; pp. 195-201.

27. Fairbridge, R.W. Syndiagenesis-anadiagenesis-epidiagenesis: Phases of lithogenesis. In Diagenesis in Sediments and Sedimentary Rocks; Larsen, G., Chilingar, G.V., Eds.; Elsevier: Amsterdam, The Netherlands, 1983; Volume 2, pp. 17-113. [CrossRef]

28. Larsen, G.; Chilingarian, G.V. Introduction-Diagenesis of sediments and rocks. In Diagenesis in Sediments and Sedimentary Rocks; Larsen, G., Chilingar, G.V., Eds.; Elsevier: Amsterdam, The Netherlands; Oxford, UK; New York, NY, USA, 1979; pp. 1-29. [CrossRef]

29. Singer, A.; Müller, G. Diagenesis in Argillaceous Sediments. In Diagenesis in Sediments and Sedimentary Rocks; Larsen, G., Chilingar, G.V., Eds.; Elsevier: Amsterdam, The Netherlands, 1983; Volume 2, pp. 115-211. [CrossRef]

30. Hümmel, K. Die Enstehung eisenreicher Gestein durch Halmyrolyse (=submarine Gesteinszersetzung). Geol. Rundsch. 1922, 13, 40-81. [CrossRef]

31. Maslennikov, V.V.; Zaykov, V.V.; Zaykova, E.V. Paleohydrothermal fields and ore formation conditions at massive sulfide deposits in the Uralian paleoocean. In Geodynamics and Metallogeny: Theory and Implications for Aplied Geology; Mezhelovsky, N.V., Morozov, A.F., Gusev, G.S., Popov, V.S., Eds.; Geokart: Moscow, Russia, 2000; pp. 339-358. (In Russian)

32. Zaykov, V.V.; Maslennikov, V.V.; Zaykova, E.V.; Herrington, R.J. Hydrothermal activity in the segments of the rift valley on the marginal Urals palaeoocean. In Tectonic, Magmatic, Hydrothermal and Biological Segmentation at the Mid-Ocean Ridges; MacLeod, C.J., Tyler, P.A., Walker, C.L., Eds.; Geological Society Special Publication: London, UK, 1996; Volume 118, pp. 199-210.

33. Fersman, A.E. Geochemistry of Russia; Nauchnoe Khimicheskoe Tekhnicheskoe Izdatel'stvo: St. Petersburg, FL, USA, 1922; 220p. (In Russian)

34. Zaykov, V.V.; Herrington, R. Mawsonite from products of submarine oxidation of the Molodezhnoe copper-sulfide deposit (South Urals). In Ural'skiy Mineralogicheskiy Sbornik; IMin UB RAS: Miass, Russia, 1998; Volume 8, pp. 40-48. (In Russian)

35. Herrington, R.J.; Armstrong, R.N.; Zaykov, V.V.; Maslennikov, V.V.; Tessalina, S.G.; Orgeval, J.-J.; Taylor, R.N. Massive sulfide deposits in the southern Urals: Geological setting within the Framework of the Uralide Orogen. In Mountain Building in the Uralides: Pangea to the Present; Brown, D., Ed.; Geophisical Monograph; American Geophysical Union: Washington, DC, USA, 2002; Volume 132, pp. 155-182. [CrossRef]

36. Herrington, R.J.; Maslennikov, V.V.; Zaykov, V.V.; Seravkin, I.B.; Kosarev, A.S.; Bushmann, B.; Orgeval, J.-J.; Holland, N.; Tessalina, S.G.; Nimis, P.; et al. Classification of VHMS deposits: Lessons from the Uralides. Ore Geol. Rev. 2005, 27, 203-237. [CrossRef]

37. Kontar, E.S.; Libarova, L.E. Geological Economic Types of Cu, Zn, and Pb Deposits of the Urals: Geological Setting, Evolution, and Prospects; Uralgeolkom: Yekaterinburg, Russian, 2013; 199p. (In Russian)

38. Koroteev, V.A.; de Boorder, H.; Necheukhin, V.M.; Sazonov, V.N. Geodynamic setting of the mineral deposits of the Urals. Tectonophysics 1997, 276, 291-300. [CrossRef]

39. Prokin, V.A.; Buslaev, F.P. Massive copper-zinc sulfide deposits in the Urals. Ore Geol. Rev. 1999, 14, 1-69. [CrossRef]

40. Puchkov, V.N. Geology of the Urals and Cis-Urals (Topical Problems of Stratigraphy, Tectonics, Geodynamics, and Metallogeny); DizainPoligraphServis: Ufa, Russia, 2010; 280p. (In Russian)

41. Seravkin, I.B. Correlation between compositions of ores and host rocks in volcanogenic massive sulfide deposits of the Southern Urals. Geol. Ore Depos. 2013, 55, 207-224. [CrossRef]

42. Seravkin, I.B.; Kosarev, A.M.; Puchkov, V.M. Geodynamic conditions of formation of massive sulfide deposits in the Magnitogorsk megazone, Southern Urals, and prospection criteria. Geol. Ore Depos. 2017, 59, 227-243. [CrossRef]

43. Spadea, P.; Kabanova, L.Y.; Scarrow, J. Petrology, geochemistry, and geodinamic significance of Mid-Devonian Boninitic rocks from the Baimak-Buribai area (Magnitogorsk zone, Southern Urals). Ofioliti 1998, 23, 17-36.

44. Tessalina, S.G.; Herrington, R.J.; Taylor, R.N.; Sundblad, K.; Maslennikov, V.V.; Orgeval, J.J. Lead isotope systematic of massive sulphide deposits in the Urals: Application for geodynamic setting and metal sources. Ore Geol. Rev. 2016, 72, 22-36. [CrossRef] 
45. Zaykov, V.V. Volcanism and Sulfide Mounds of Paleocean Margins (after Example of the Ural's and Siberia's Massive Sulfide-Bearing Zones); Nauka: Moscow, Russia, 2006; 428p. (In Russian)

46. Kontar, E.S. Quantitative estimation of massive sulfide ore formation. Geol. Ore Depos. 2002, 44, 543-555.

47. Eremin, N.I.; Dergachev, A.L.; Sergeeva, N.E.; Pozdnyakova, N.V. Types of massive sulfide deposits of volcanic association. Geol. Ore Depos. 2000, 42, 177-190.

48. Seravkin, I.B. The Metallogeny of the Southern Urals and the Central Kazakhstan; Gilem: Ufa, Russia, 2010; 281p. (In Russian)

49. Maslennikov, V.V.; Maslennikova, S.P.; Large, R.R.; Danyushevskiy, L.V.; Herrington, R.J.; Stanley, C.J. Tellurium-bearing minerals in zoned sulfide chimneys from $\mathrm{Cu}-\mathrm{Zn}$ massive sulfide deposits of the Urals, Russia. Mineral. Petrol. 2013, 107, 67-99. [CrossRef]

50. Maslennikov, V.V.; Maslennikova, S.P.; Ayupova, N.R.; Zaykov, V.V.; Tseluyko, A.S.; Melekestseva, I.Y.; Large, R.R.; Danyushevsky, L.V.; Herrington, R.J.; Lein, A.T.; et al. Chimneys in Paleozoic massive sulfide mounds of the Urals VMS deposits: Mineral and trace element comparison with modern black, grey, white and clear smokers. Ore Geol. Rev. 2017, 85, 64-106. [CrossRef]

51. Franklin, J.M.; Gibson, H.L.; Jonasson, I.R.; Galley, A.G. Volcanogenic massive sulfide deposits. In Economic Geology One Hundredth Anniversary Volume; Hedenquist, J.W., Thompson, J.F.H., Goldfarb, R.J., Richards, J.P., Eds.; Society of Economic Geologist: Littleton, CO, USA, 2005; pp. 523-560. [CrossRef]

52. Zaykov, V.V.; Melekestsev, I.Y.; Artemyev, D.A.; Yuminov, A.M.; Simonov, V.A.; Dunaev, A.Y. Geology and Massive Sulfide Mineralization of the Southern Flank of the Main Uralian Fault; Geotur: Miass, Russia, 2009; 376p. (In Russian)

53. Melekestseva, I.Y.; Zaykov, V.V.; Nimis, P.; Tret'yakov, G.A.; Tesalina, S.G. Cu-(Ni-Co-Au)-bearing massive sulfide deposits associated with mafic-ultramafic rocks of the Main Urals Fault, South Urals: Geological structures, ore textural and mineralogical features, comparison with modern analogs. Ore Geol. Rev. 2013, 52, 18-37. [CrossRef]

54. Prokin, V.A.; Seravkin, I.B.; Vinogradov, A.M. Geological conditions of distribution and prognostic perspectives of large massive copper-sulfide deposits in the Urals. Litosfera 2011, 6, 123-133. (In Russian)

55. Zaykov, V.V.; Maslennikov, V.V. Seafloor sulfide mounds of massive sulfide deposits of the Urals. Dokl. Akad. Nauk USSR 1987, 293, 181-184. (In Russian)

56. Zhabin, A.G.; Sharfman, V.S.; Samsonova, N.S. Interpretation of conditions of Devonian volcanosedimentary sulfide deposition. Geol. Rudn. Mestorozh. 1974, 13, 60-75. (In Russian)

57. Eldridge, C.S.; Barton, P.B.; Ohmoto, H. Mineral textures and their bearing on formation of the Kuroko orebodies. In The Kuroko and Related Volcanogenic Sulfide Deposits; Ohmoto, H., Skinner, B.J., Eds.; Economic Geology Monograph; Society of Economic Geologist: Littleton, CO, USA, 1983; Volume 5, pp. 241-281.

58. Ayupova, N.R.; Maslennikov, V.V.; Maslennikova, S.P.; Blinov, I.A.; Danyushevsky, L.V.; Large, R.R. Rare mineral and trace element assemblages in submarine supergene zone at the devonian Molodezhnoye VMS deposit, the Urals, Russia. In Proceedings of the 13 SGA Biennial Meeting, Nancy, France, 24-27 August 2015; Volume 5, pp. 2051-2054.

59. Eremin, N.I.; Sergeeva, N.E.; Dergachev, A.L. Rare minerals from massive sulfide ores: Typomorphic features and geochemical trend. Mosc. Univ. Geol. Bull. 2007, 62, 85-106. (In Russian) [CrossRef]

60. Grabezhev, A.I.; Moloshag, V.P.; Sotnikov, V.I.; Murzin, V.V.; Korovko, A.V.; Zhukhlistov, A.P. Metasomatic halo of the Saf'yanovskoe Zn-Cu deposit (Central Urals). Petrologiya 2001, 9, 294-312. (In Russian)

61. Vikentyev, I.V.; Belogub, E.V.; Novoselov, R.A.; Moloshag, V.P. Metamorphism of volcanogenic massive sulphide deposits in the Urals. Ore Geol. Rev. 2017, 85, 30-63. [CrossRef]

62. Herrington, R.J.; Maslennikov, V.V.; Spiro, B.; Zaykov, V.V.; Little, C.T.S. Ancient vent chimney structures in the Silurian massive sulfides of the Urals. In Modern Ocean Floor Processes and the Geological Record; Mills, R.A., Harrison, K., Eds.; Geological Society Special Publication: London, UK, 1998; Volume 148, pp. 241-257. [CrossRef]

63. Little, C.T.S.; Herrington, R.J.; Maslennikov, V.V.; Morris, N.J.; Zaykov, V.V. Silurian hydrothermal-vent community from the southern Urals, Russia. Nature 1997, 385, 146-148. [CrossRef]

64. Maslennikov, V.V.; Maslennikova, S.P.; Large, R.R.; Danyushevsky, L.V. Study of trace element zonation in vent chimneys from the Silurian Yaman-Kasy VMS (the Southern Urals, Russia) using laser ablation inductively coupled plasma mass spectrometry (LA-ICP MS). Econ. Geol. 2009, 104, 1111-1141. [CrossRef] 
65. Shadlun, T.N. Some sulfide intergrowths in modern and ancient massive sulfide ores. Geol. Rudn. Mestorozh. 1991, 33, 110-118. (In Russian)

66. Ayupova, N.R. Marsturite from the Uzelga massive sulfide field (Southern Urals). Zap. Vseross. Miner. Obshch. 2003, 4, 58-61. (In Russian)

67. Tseluyko, A.S.; Maslennikov, V.V.; Artem'yev, D.A. Microtopochemistry of pyrite nodules of siliceous siltstones from the Yubileinoe massive sulfide deposit (the Southern Urals) according to LA-ICP-MS data. Litosfera 2018, 18, 621-641. (In Russian) [CrossRef]

68. Maslennikova, S.P.; Maslennikov, V.V. Paleozoic Black Smoker Sulfide Chimneys; Ural Branch of RAS: Yekaterinburg, Russia, 2007; 312p. (In Russian)

69. Criddle, A.J.; Chisholm, J.E.; Stanley, C.J. Cervelleite, $\mathrm{Ag}_{4} \mathrm{TeS}$, a new mineral from the Bambolla mine, Mexico, and description of a photo-chemical reaction involving cervelleite, acantite and hessite. Eur. J. Mineral. 1989, 1, 371-380. [CrossRef]

70. Kolotov, S.V.; Gmyra, V.G. Rare minerals of the Molodeyzhnoe massive sulfide deposit. In Yezhegodnik-1989; Institute of Geology and Geochemistry UB RAS: Yekaterinburg, Russia, 1989; pp. 78-80. (In Russian)

71. Moloshag, V.P.; Vikentiev, I.V. Germanium mineralization of massive sulfide deposits of the Urals. Vestnik Ural'skogo Otdeleniya RMO 2009, 6, 79-84. (In Russian)

72. Trudu, A.G.; Knittel, U. Crystallography, mineral chemistry and chemical nomenclature of goldfieldite, the tellurian member of the tetrahedrite solid-solution series. Can. Mineral. 1998, 36, 1115-1137. [CrossRef]

73. Tessalina, S.G.; Maslennikov, V.V.; Surin, T.N. Aleksandrinskoe Copper-Zinc Massive Sulfide Deposit (East-Magnitogorsk Paleoisland Arc, Urals); Institute of Mineralogy UB RAS: Miass, Russia, 1998; 228p. (In Russian)

74. Dobrovolskaya, M.U.; Distler, V.V. Platinum minerals in ores of the Urals copper massive sulfide deposits. Rudy Met. 1998, 4, 56-64. (In Russian)

75. Moloshag, V.P.; Vikentiev, I.V.; Gulyaeva, T.Y.; Tesalina, S.G. Precious and rare metals of bornite in ores from massive sulfide deposits of the Urals. Zap. Vseros. Miner. Obshch. 2005, 134, 53-69. (In Russian)

76. Arkhireeva, N.S.; Kotlyarov, V.A. Mineral composition of Fe-poor ferruginous and carbonaceous shales from the Aleksandrinskoe and Saf'yanovskoe deposits (the Urals). Mineralogiya 2016, 2, 60-69. (In Russian)

77. Safina, N.P.; Ayupova, N.R. Diagenetic bournonite in clastic ores of the Saf'yanovskoe copper-zinc massive sulfide deposit, the Central Urals. Zap. Vseross. Miner. Obshch 2017, CXLVI, 73-87. (In Russian)

78. Zaykov, V.V.; Maslennikov, V.V.; Zaykova, E.V.; Herrington, R. Ore-Formational and Ore-Facies Analysis of Massive Sulfide Deposits of Ural Paleo-Ocean; Imin UB RAS: Miass, Russia, 2001; 315p. (In Russian)

79. Safina, N.P.; Melekestseva, I.Y.; Nimis, P.; Ankusheva, N.N.; Yuminov, A.M.; Kotlyarov, V.A.; Sadykov, S.A. Barite from the Saf'yanovka VMS deposit (Central Urals) and Semenov-1 and Semenov-3 hydrothermal sulfide fields (Mid-Atlantic Ridge): A comparative analysis of formation conditions. Miner. Depos. 2016, 54, 491-507. [CrossRef]

80. Ayupova, N.R.; Maslennikov, V.V. Halmyrolytites of the Uzelga Massive Sulfide Bearing Field, Southern Urals; Urals Branch of the Russian Academy of Science: Miass, Russia, 2005; 199p. (In Russian)

81. Hannington, M.D.; Bleeker, W.; Kjarsgaard, I. Sulfide mineralogy, geochemistry and ore genesis of the Kidd Creek Deposit: Part I. Noth, Central and South orebodies. In The Giant Kidd Creek Volcanogenic Massive Sulfide Deposit, Western Abitibi Subprovince, Canada; Hannington, M.D., Barrie, T.C., Eds.; Economic Geology Monograph; Society of Economic Geologist: Littleton, CO, USA, 1999; Volume 10, pp. 163-224. [CrossRef]

82. Safina, N.P.; Maslennikov, V.V.; Maslennikova, S.P.; Kotlyarov, V.A.; Danyushevsky, L.V.; Large, R.R.; Blinov, I.A. Banded sulfide-magnetite ores of Mauk copper massive sulfide deposit, Central Urals: Composition and genesis. Geol. Ore Depos. 2015, 57, 197-212. [CrossRef]

83. Hannington, M.D.; Bleeker, W.; Kjarsgaard, I. Sulfide Mineralogy, Geochemistry, and Ore Genesis of the Kidd Creek Deposit: Part II. The Bornite Zone. In The Giant Kidd Creek Volcanogenic massive Sulfide Deposit, Western Abitibi Subprovince, Canada; Hannington, M.D., Barrie, T.C., Eds.; Economic Geology Monograph; Society of Economic Geologist: Littleton, CO, USA, 1999; pp. 225-266. [CrossRef]

84. Maslennikov, V.V.; Zaykov, V.V. Method of Ore-Facies Analysis in Geology of Massive Sulfide Deposits; SUSU: Chelyabinsk, Russia, 2006; 224p. (In Russian)

85. Goodfellow, W.D.; Blaise, B. Sulfide formation and hydrothermal alteration of hemipelagic sediment in Middle Valley, Northern Juan de Fuca Ridge. Can. Mineral. 1988, 26, 675-696. 
86. Goodfellow, W.D.; Franklin, J.M. Geology, mineralogy, and geochemistry of sediment-hosted clastic massive sulfides in shallow cores, Middle Valley, northern Juan-de-Fuca ridge. Econ. Geol. 1993, 88, 2037-2068. [CrossRef]

87. Skripchenko, N.S. Hydrothermal-Sedimentary Sulfide Ores of Basaltic Complexes; Nauka: Moscow, Russia, 1972; 217p. (In Russian)

88. Skripchenko, N.S. Hydrothermal-Sedimentary Polymetallic Ores of Lime-Shale Complexes; Nauka: Moscow, Russia, 1980; 215p. (In Russian)

89. Safina, N.P.; Maslennikov, V.V. Sequence of mineral formation in clastic ores of the Safyanovka volcanic-hosted copper massive sulfide deposit, the Central Urals. Geol. Ore Depos. 2009, 51, 633-643. [CrossRef]

90. Skinner, B.J. The system Cu-Ag-S. Econ. Geol. 1966, 61, 1-26. [CrossRef]

91. Vogan, D.; Kreig, D. Chemistry of Sulphide Minerals; Mir: Moscow, Russia, 1981; 575p. (In Russian)

92. Auclair, G.; Fouquet, Y.; Bohn, M. Distribution of selenium in high-temperature hydrothermal sulfide deposits at $13^{\circ}$ North, East Pacific Rise. Can. Mineral. 1987, 87, 577-587.

93. Hannington, M.D.; Jonasson, I.R.; Herzig, P.M.; Petersen, S. Physical, chemical processes of seafloor mineralization at Mid-Ocean Ridges. In Seafloor Hydrothermal Systems: Physical, Chemical, Biological, and Geological Interactions; Humphris, R.A., Zierenberg, R., Mullineau, L., Thompson, R., Eds.; Geophysical Monograph; American Geophysical Union: Washington, DC, USA, 1995; Volume 91, pp. 115-157. [CrossRef]

94. Butler, I.B.; Nesbitt, R.V. Trace element distribution in the chalcopyrite wall of a black smoker chimney: Insights from laser ablation inductively coupled plasma mass spectrometry (LA-ICP-MS). Earth Planet. Sci. Lett. 1999, 167, 335-345. [CrossRef]

95. Keith, M.; Häckel, F.; Haase, K.M.; Schwarz-Schampera, U.; Klemd, R. Trace element systematics of pyrite from submarine hydrothermal vents. Ore Geol. Rev. 2016, 72, 728-745. [CrossRef]

96. Wohlgemuth-Ueberwasser, C.C.; Viljoen, F.; Petersen, S.; Vorster, C. Distribution and solubility limits of trace elements in hydrothermal black smoker sulfides: An in-situ LA-ICP-MS study. Geochim. Cosmochim. Acta 2015, 159, 16-41. [CrossRef]

97. Rouxel, O.; Fouquet, Y.; Ludden, J.N. Subsurface processes at the Lucky Strike hydrothermal field, Mid-Atlantic ridge: Evidence from sulfur, selenium, and iron isotopes. Geochim. Cosmochim. Acta 2004, 68, 2295-2311. [CrossRef]

98. Ayupova, N.R.; Maslennikov, V.V.; Kotlyarov, V.A.; Maslennikova, S.P.; Danyushevsky, L.V.; Large, R. Se and in minerals of in the Submarine Oxidation Zone of the Molodezhnoe Copper-Zinc Massive Sulfide Deposit, Southern Urals. Dokl. Earth Sci. 2017, 473, 318-322. [CrossRef]

99. Akinfiev, N.N.; Tagirov, B.R. Effect of selenium on silver transport and precipitation by hydrothermal solution: Thermodynamic description of the Ag-Se-S-Cl-OH system. Geol. Ore Depos. 2006, 48, 402-413. [CrossRef]

100. Large, R.R.; Bull, S.W.; Maslennikov, V.V. A carbonaceous sedimentary source-rock model for Carlin-type and Orogenic Gold deposits. Econ. Geol. 2011, 106, 331-358. [CrossRef]

101. Thomas, H.V.; Large, R.R.; Bull, S.W.; Maslennikov, V.V.; Berry, R.F.; Fraser, R.; Froud, S.; Moye, R. Pyrite and pyrrhotite textures and composition in Sedimentary rocks, laminated quartz veins, and gold reefs, at Bendigo Mine, Austarlia: Insights for ore genesis. Econ. Geol. 2011, 105, 1-40. [CrossRef]

102. Ismagilov, M.I.; Loginov, V.P.; Vasil'eva, G.L. Zonality of ore deposition of the Ozernoe massive sulfide deposit (the Southern Urals) and some formation conditions of its pyrrhotite ores. In The Problems of Physicochemical Petrology; Nauka: Moscow, Russia, 1979; Volume 2, pp. 184-200. (In Russian)

103. Roberts, A.P.; Zhao, X.; Harrison, R.J.; Helslop, D.; Muxworthy, A.R.; Roman, C.J.; Larrasoana, J.-C.; Florindo, F. Signature of reductive magnetic mineral diagenesis from unmixxing of first-order reversal curves. J. Geophys. Res. 2018, 123, 4500-4522. [CrossRef]

104. Hannington, M.D.; Scott, S.D. Mineralogy and geochemistry of hydrothermal silica-sulfide-sulfate spire in the Caldera of Axial Seamount, Juan de Fuca Ridge. Can. Mineral. 1988, 26, 603-625.

105. Törmänen, T.O.; Koski, R.A. Gold enrichment and the Bi-Au association in pyrrhotite-rich massive sulfide deposits, Escanaba Trough, southern Gorda Ridge. Econ.Geol. 2005, 100, 1135-1150. [CrossRef]

106. Pshenichny, G.N. Textures and Structures of Ores of Massive Sulfide Deposits of the Southern Urals; Nauka: Moscow, Russia, 1984; 207p. (In Russian) 
107. Vikentyev, I.V.; Belenkaya, Y.A.; Ageev, B.I. Aleksandrinskoe polymetallic massive sulfide deposit (the Urals, Russia). Geol. Ore Depos. 2000, 42, 221-246.

108. Vikentyev, I.V. Precious metal and telluride mineralogy of large vocanic-hosted massive sulfide deposits in the Urals. Mineral. Petrol. 2006, 87, 305-326. [CrossRef]

109. Moloshag, V.P.; Grabezhev, A.I.; Vikentiev, I.V.; Gulyaeva, T. Ore formation of massive sulfide ore deposits and copper-gold-porphyry deposits of the Urals. Litosfera 2004, 2, 30-51. (In Russian)

110. Moloshag, V.P.; Grabezhev, A.I.; Gulyaeva, T.Y. Conditions of telluride formation in ores of the Urals massive sulfide and copper-gold-porphyry deposits. Zap. Vseros. Miner. Obshch 2002, 131, 40-53. (In Russian)

111. Belogub, E.V.; Novoselov, K.A.; Kotlyarov, V.A. Germanium minerals in ores of the Babaryk massive sulfide deposit, South Urals. In Proceedings of the Metalogeny of modern and ancient oceans, Miass, Russia, 25-30 April 2005; Imin UB RAS: Miass, Russia, 2005; pp. 123-128. (In Russian)

112. Novoselov, K.A.; Belogub, E.V.; Kotlyarov, V.A. Germanium minerals in sulfide ores of the deposits of the Aleksandrinsky ore district. In Ural'skiy Mineralogicheskiy Sbornik; IMin UB RAS: Miass, Russia, 2007; Volume 14, pp. 96-104. (In Russian)

113. Novoselov, K.A.; Belogub, E.V.; Zaykov, V.V.; Yakovleva, V.A. Silver sulfotellurides from volcanic-hosted massive sulfide deposits in the Southern Urals. Mineral. Petrol. 2006, 83, 327-349. [CrossRef]

114. Ayupova, N.R.; Novoselov, K.A.; Belogub, E.V. Ferruginous-siliceous sediments as the indicators of massive-sulfide deposits (on example of the Babaryk ore field, Southern Urals). Litosfera 2011, 3, 117-134. (In Russian)

115. Belogub, E.V.; Novoselov, K.A.; Yakovleva, V.A.; Spiro, B. Supergene sulphides and related minerals in the supergene profiles of VHMS deposits from the South Urals. Ore Geol. Rev. 2008, 33, 239-254. [CrossRef]

116. Ohmoto, H. Formation of volcanogenic massive sulfide deposits: The Kuroko perspective. Ore Geol. Rev. 1996, 10, 135-177. [CrossRef]

117. Feely, R.A.; Lewison, M.; Massoth, J.W.; Massoth, G.J.; Robert-Baldo, G.; Lavelle, J.W.; Byrne, R.H.; Von Damm, K.L.; Curl, H.C. Composition and dissolution of black smoker particulates from active vents on the Juan de Fuca Ridge. J. Geophys. Res. 1987, 92, 11347-11363. [CrossRef]

118. Eremin, N.I.; Sergeeva, N.E.; Shishakov, V.O. Finding a Pd-bearing melonite in copper-rich sulfide ores of the Pyshminsko-Kluchevskoe deposit in the Urals. Dokl. Earth Sci. 1997, 355, 795-797.

119. Belogub, E.V.; Moloshag, V.P.; Novoselov, K.A.; Kotlyarov, V.A. Native bismuth, tsumoite, and Pb-bearing tsumoite from the Tarn'er copper-zinc massive sulfide deposit, Northern Urals. Geol. Ore Depos. 2011, 53, 798-805. [CrossRef]

120. Maslennikov, V.V.; Tretyakov, G.A. Physicochemical modeling of the sequence of mineral formation with submarine hypergenesis of massive sulfide deposits of the Urals and Kuroko types. In Ural'skiy Mineralogicheskiy Sbornik; IMin UB RAS: Miass, Russia, 2008; Volume 15, pp. 9-17. (In Russian) 